\title{
Assessment of Energy-Positive Wastewater Treatment System Design of Different Industrial Wastewater Streams
}

\section{Jinze Li}

Florida International University

Walter Z. Tang ( $\boldsymbol{\nabla}$ tangz@fiu.edu )

Florida International Univversity https://orcid.org/0000-0002-3232-8057

\section{Research Article}

Keywords: Meat processing wastewater, Tannery wastewater, Textile wastewater, COD removal, Cost estimation Excel model

Posted Date: May 27th, 2021

DOI: https://doi.org/10.21203/rs.3.rs-507038/v1

License: (c) (1) This work is licensed under a Creative Commons Attribution 4.0 International License. Read Full License 
Jinze $\mathrm{Li}^{\mathrm{a}}$

7

Walter Z. Tang a, *

8

9

10 aDepartment of Civil and Environmental Engineering, Florida International University,

11 Miami, FL-33174, USA.

12

$13{ }^{*}$ Corresponding author: Department of Civil and Environmental Engineering, Florida

14 International University, Miami, US. Email address: tangz@,fiu.edu (Walter Z. Tang) 15 


\section{Abstract}

Activated sludge (AS) process has been used as the conventional industrial wastewater treatment process in the past decades. However, intensive aeration requirements made it impossible for WWTPs to be energy positive. In addition, there are few cases of research assessing the efficiency and economic feasibility of innovative technologies in treating industrial wastewater to achieve energy positive. This study tries to assess the effect of different kinds of industrial wastewater on treatment efficiency, unit energy, environmental sustainability, and unit cost of treatment systems using innovative technologies such as micro sieving, UASB, and PN/A. Our Excel model showed that micro-sieving could remove 32.50-39.72\% of COD from industrial wastewater. UASB reactor could removes $15.8 \%-53.5 \%, 14.0 \%-49.0 \%$ and $22.9 \%-$ $51.0 \%$ of COD from three different wastewater streams. Mean unit energy production by the innovative system could reach $1.80,1.77$, and $1.73 \mathrm{kWh} / \mathrm{kg} \mathrm{BOD}_{\text {removed, }}$ respectively. The average unit cost of three kinds of wastewater is $0.54,0.57$, and 1.12 $\$ / \mathrm{kg} \mathrm{COD}_{\text {removed, }}$ respectively. Treating meat processing wastewater with innovative technologies is the economical treatment method. However, this method could not be considered as the sustainable design due to the high effluent COD concentration. The economic advantages and limitations of innovative technologies in treating industrial wastewater have been quantified by energy, cost and environmental indicators. These metrics provide valuable references for future sustainable design of industrial wastewater treatment systems. 


\section{Introduction}

Industrial wastewater has vastly different water quality. For example, the water quality of food processing, pulp and paper, textile, chemical, pharmaceutical, petroleum, tannery, and manufacturing industries varied significantly [1]. Major wastewater quality parameters include chemical oxygen demand (COD), biochemical oxygen demand (BOD), suspended solids (SS), ammonium nitrogen $\left(\mathrm{NH}_{4}{ }^{+} \mathrm{N}\right)$, heavy metals, $\mathrm{pH}$, color, turbidity, and biological parameters. Compared with municipal wastewater, industrial wastewaters usually have a high organic matter concentration and extreme physicochemical characters (e.g., pH, temperature, salinity), and humic substances that may inhibit biological treatment processes. In addition, municipal wastewater has a low strength concentration of COD $(250-800 \mathrm{mg} / \mathrm{L})$, whereas strong (>1,000 mg COD/L) to extremely strong wastewaters is often produced by industries [2]. Olive mills and beverage production industries could generate extremely strong industrial wastewaters (COD>200,000 mg/L) [3, 4]. Characteristics of industrial wastewaters strongly depend on the type of industrial wastewaters and industrial processes. Water used by meat processing industries accounts for $29 \%$ of the agricultural freshwater worldwide [5, 6]. Food processing wastewater is typically generated from the slaughtering houses. Typically, there is a large quantity of suspended organic matter, protein, and fat (i.e., bones, meat, and viscera) in meat processing wastewater. Therefore, a high concentration of COD, BOD, TN, and TSS is typical in food processing wastewater [7-9]. The average COD, BOD, TN and TSS concentration of food wastewater could reach as high as 4,221 mg/L, 1,209 mg/L, 427 $\mathrm{mg} / \mathrm{L}$, and 1,164 mg/L, respectively [10]. Meat processing wastewater is considered as one of the most detrimental food industrial wastewaters because its inadequate disposal could lead to river deoxygenation, algal blooms, and eutrophication [11, 12]. 
The tannery industry, which could be defined as the production process of leather by treating sheep and goat skins and bovine hides, is one of the oldest industries worldwide [13]. Leather is one of the few available materials to produce clothing and footwear because of its unique properties [14]. However, tannery industry consumes large amounts of water and chemicals. Wastewaters are mainly produced during the wet processes of tannery industry. To produce $250 \mathrm{~kg}$ of leather, $15-80 \mathrm{~m}^{3}$ of tannery wastewater with 230-250 kg COD, $100 \mathrm{~kg}$ BOD, $150 \mathrm{~kg}$ TSS, 5-6 kg chrome, and 10 $\mathrm{kg}$ sulphide is produced $[15,16]$. Tannery effluents are characterized by high pollution loads of conventional pollutants and suspended solids with low BOD/COD ratio, which cause deterioration of the receiving natural water bodies if it were inadequately treated [17-24].

Textile industry, representing one of the largest and most widespread production industries in the world, produces a large number of dyestuffs $\left(>7 \times 10^{5}\right.$ tons) per year worldwide [25]. Textile industry produces a large amount of processing wastewater containing variety of chemicals. For example, wastewater with dyestuff, surface-active agents, and additives are generated from spent dye bath and rinsing waters [26-28]. Textile effluent is typically a complex mixture of organic and inorganic matters with strong color, high $\mathrm{COD}$, high salinity, high temperature, variable $\mathrm{pH}$, and low BOD $[29,30]$. The direct discharge of textile wastewater into rivers and streams could cause severe environmental problems [31]. Commercial dyes in textile effluent are carcinogenic to humans and toxic to aquatic organisms [27, 32-34]. The discharge of untreated textile wastewater deteriorates water quality, adversely impacts aquatic life and crops [35-37].

Biological and chemical processes are traditionally used in treating meat processing, tannery, and textile wastewater [38-58]. Physical and chemical methods 
are very expensive because they consume a large amount of energy and chemicals with excessive sludge [59-61]. Compared with oxidation process and chemical processes, biological treatment methods have numerous advantages: (1) low capital and operating costs; (2) oxidation of a wide variety of organic matters rather phase transfer separation such as air stripping or carbon adsorption; (3) removal of reduced inorganic compounds, such as ammonia, and total nitrogen removal by nitrification and denitrification; and (4) operational flexibility to treat different kinds of wastewater with a wide range of flows.

The unit energy consumption of meat processing plants using biological process was reported as $0.81 \mathrm{kWh} / \mathrm{kg}$ COD [62]. Yang et al. [63] compared the performance and energy of textile wastewater treatment by conventional activated sludge (CAS), MBR, and Moving bed biofilm reactor (MBBR). Results showed that the unit energy consumption of CAS is $0.58 \mathrm{~kW} / \mathrm{kg}$ COD. Activated sludge (AS) system with autotrophic nitrification/heterotrophic denitrification (NDN) process with primary clarifier were conventional processes in industrial and municipal wastewater treatment. However, they consume high energy, have large footprints, and produce a large amount of sludge as compared with innovative biological technologies such as micro sieving, UASB, and PN/A, which are the major focus of this study.

Micro-sieving is one of the most sustainable technologies in separate TSS from wastewater stream at the early stage of treatment processes. As a result, it significantly reduces operation costs and has less footprint. Mainstream UASB could achieve energy recovery by converting $\mathrm{COD}$ to biogas without consuming $\mathrm{O}_{2}$ at operating temperatures between 15 and $35^{\circ} \mathrm{C}[64,65]$. PN/A, which is an innovative $\mathrm{N}$ removal technology discovered in the 1990s [66-68], could remove 90\% of $\mathrm{NH}_{4} \_\mathrm{N}$ through converting ammonia and nitrite $\mathrm{N}_{2}$ in Anammox process [69-72]. Compared with the 
conventional nitrification/denitrification (NDN) process, PN/A process could reduce

$117 \mathrm{O}_{2}$ demand during nitrification by approximately $60 \%$, eliminate external organic

118 carbon source, and decrease sludge by 80-90\% [73-75]. Currently, there are few cases

119 of research assessing the efficiency and economic feasibility of innovative technology

120 in treating different kinds of industrial wastewater. Therefore, the effects of different

121 kinds of industrial wastewater on the performance, energy, and cost of using micro-

122 sieving, UASB, and PN/A were quantified from energy, cost, and sustainability metrics.

123 The objectives of this study are to (1) evaluate the influence of different industrial

124 wastewater on the performance of primary treatment and secondary treatment; (2)

125 compare the unit energy consumption of different industrial wastewater treatment with

126 the energy benchmark value of PN/A; (3) analyze the unit cost of the innovative

127 treatment systems in treating three different industrial wastewater streams. In addition,

128 the economic advantages and limitations of innovative technologies in treating different

129 industrial wastewater are addressed to offer insight into sustainable treatment design of

130 different industrial wastewaters.

131 2. Material and methods

132

133

134

\subsection{Data and process flow}

In the current study, energy and cost were calculated based on three different kinds of industrial wastewater streams, namely, meat processing, tannery, and textile wastewater. Wastewater quality data were collected from published peer-reviewed papers as shown in Table 1. Database of untreated wastewater quality included the concentrations of TSS, COD, BOD, and $\mathrm{NH}_{4}{ }^{+} \_\mathrm{N}$. The concentration of TSS, COD, $\mathrm{BOD}$, and $\mathrm{NH}_{4}{ }^{+}{ }_{-} \mathrm{N}$ of meat processing wastewater is higher than those of tannery wastewater and textile wastewater. 
141 wastewater treatment systems with different primary and secondary treatment

142 processes were designed [76-81]. Figures 1 and 2 show the flow diagram of industrial

143 wastewater treatment systems. In all systems, the screen and grit chamber were used

144 as the preliminary treatment in removing large particulate matter from wastewater. The

145 difference between systems is the primary and secondary treatment processes. In

146 systems A and B, primary clarifier and micro-sieving removed particulate COD and $\mathrm{N}$

147 and produced a certain amount of primary sludge, which results in the performance

148 difference of aerobic treatment, UASB, PN/A reactor, and side stream AD design. The

149 nitrification-denitrification process was used as the main system of system A in treating

150 wastewater to meet the discharge requirement by converting biodegradable COD and

$151 \mathrm{~N}$ to $\mathrm{CO}_{2}$ and $\mathrm{N}_{2}$. System $\mathrm{B}$ used mainstream UASB and PN/A as the main processes

152 in removing soluble $\mathrm{BOD}$ and $\mathrm{N}$, which reduces aeration consumption through

153 decreasing BOD and $\mathrm{N}$ loading to the nitrification-denitrification system. To meet

154 discharge requirements and compare the performance of the wastewater treatment

155 system for different industrial wastewater, system B use UASB, PN/A, and NDN to

156 achieve the same effluent BOD and $\mathrm{N}$ concentration as system A.

Table 1 Industrial Wastewater quality

\begin{tabular}{|c|c|c|c|c|c|}
\hline $\begin{array}{c}\text { Type of } \\
\text { wastewater }\end{array}$ & TSS & BOD & COD & $\mathbf{T N}$ & Reference \\
\hline \multirow{6}{*}{$\begin{array}{c}\text { Meat } \\
\text { processing } \\
\text { wastewater }\end{array}$} & 950.00 & 1200.00 & 2100.00 & 220.00 & [82] \\
\hline & 1400.00 & 1070.00 & 2350.00 & 317.22 & [83] \\
\hline & 1164.00 & 1209.00 & 4221.00 & 427.00 & [10] \\
\hline & 662.00 & 891.00 & 1697.00 & 246.00 & [84] \\
\hline & 625.00 & 1320.00 & 3900.00 & 217.00 & [85] \\
\hline & 3438.22 & 1602.00 & 5422.25 & 361.25 & [86] \\
\hline \multirow{7}{*}{$\begin{array}{c}\text { Tannery } \\
\text { wastewater }\end{array}$} & 890.00 & 665.83 & $2,290.00$ & 282.00 & [87] \\
\hline & $2,690.00$ & $1,470.00$ & $3,700.00$ & 293.93 & [13] \\
\hline & 915.00 & $1,024.89$ & $2,155.00$ & 228.00 & [13] \\
\hline & $1,147.00$ & $1,126.00$ & $3,114.00$ & 131.70 & [13] \\
\hline & $2,229.00$ & $1,760.00$ & $5,094.00$ & 358.00 & [88] \\
\hline & $1,150.00$ & $1,746.00$ & $6,240.00$ & 327.00 & [89] \\
\hline & $1,550.00$ & 463.25 & $3,280.00$ & 260.00 & [87] \\
\hline \multirow{3}{*}{$\begin{array}{c}\text { Textile } \\
\text { wastewater }\end{array}$} & 137.00 & 455.00 & 1411.00 & 49.20 & [90] \\
\hline & 324.00 & 283.00 & 513.00 & 28.70 & [91] \\
\hline & 150.00 & 150.00 & 910.00 & 40.00 & [92] \\
\hline
\end{tabular}




\begin{tabular}{|l|l|l|l|l|l|}
\hline \multirow{2}{*}{} & 460.00 & 198.00 & 714.00 & 18.70 & {$[93]$} \\
\cline { 2 - 6 } & 520.00 & 225.00 & 770.00 & 23.00 & {$[93]$} \\
\cline { 2 - 6 } & 438.00 & 220.00 & 798.00 & 24.70 & {$[93]$} \\
\hline
\end{tabular}

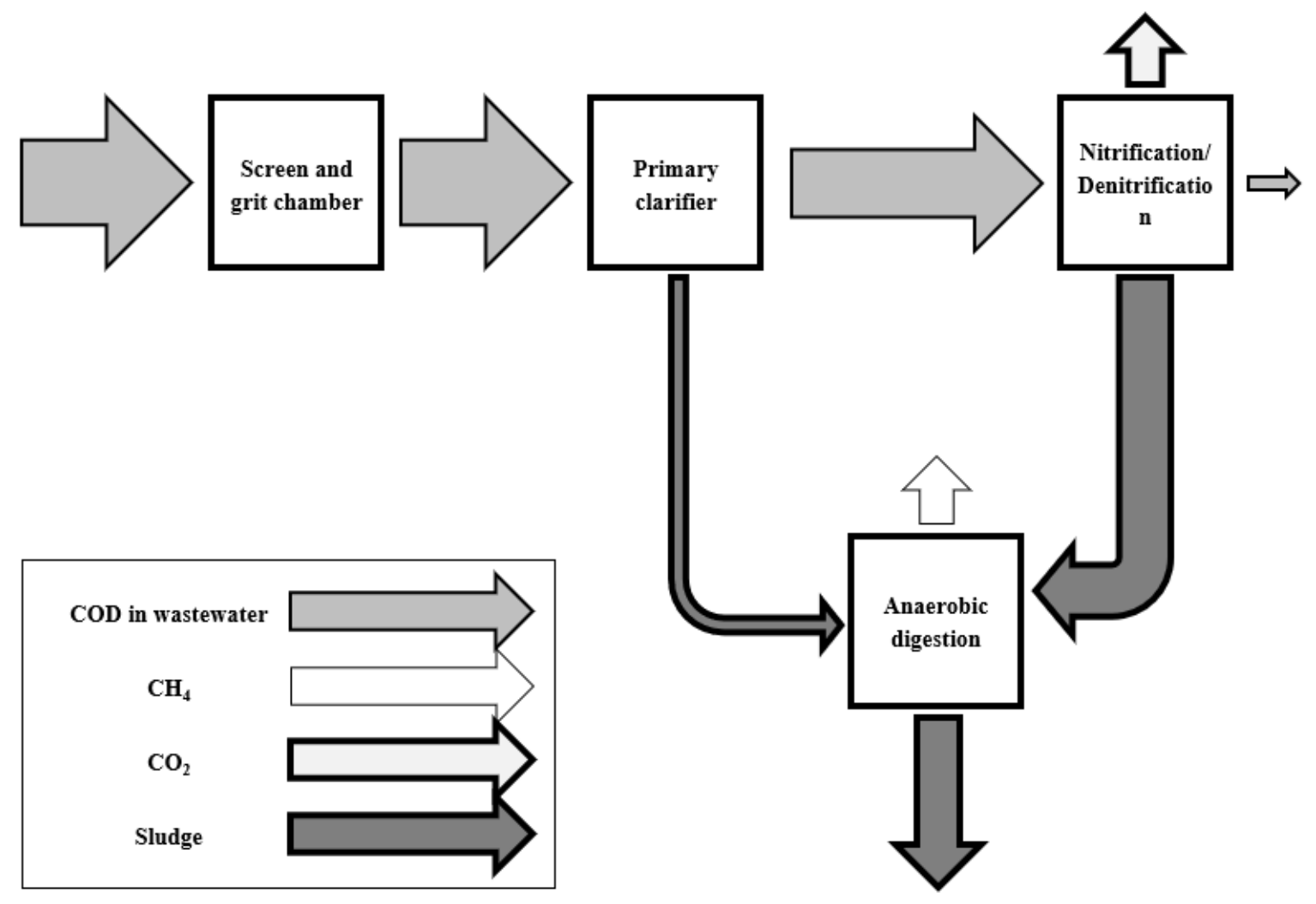

160 Figure 1 Schematic graphs of wastewater treatment system A- activated sludge

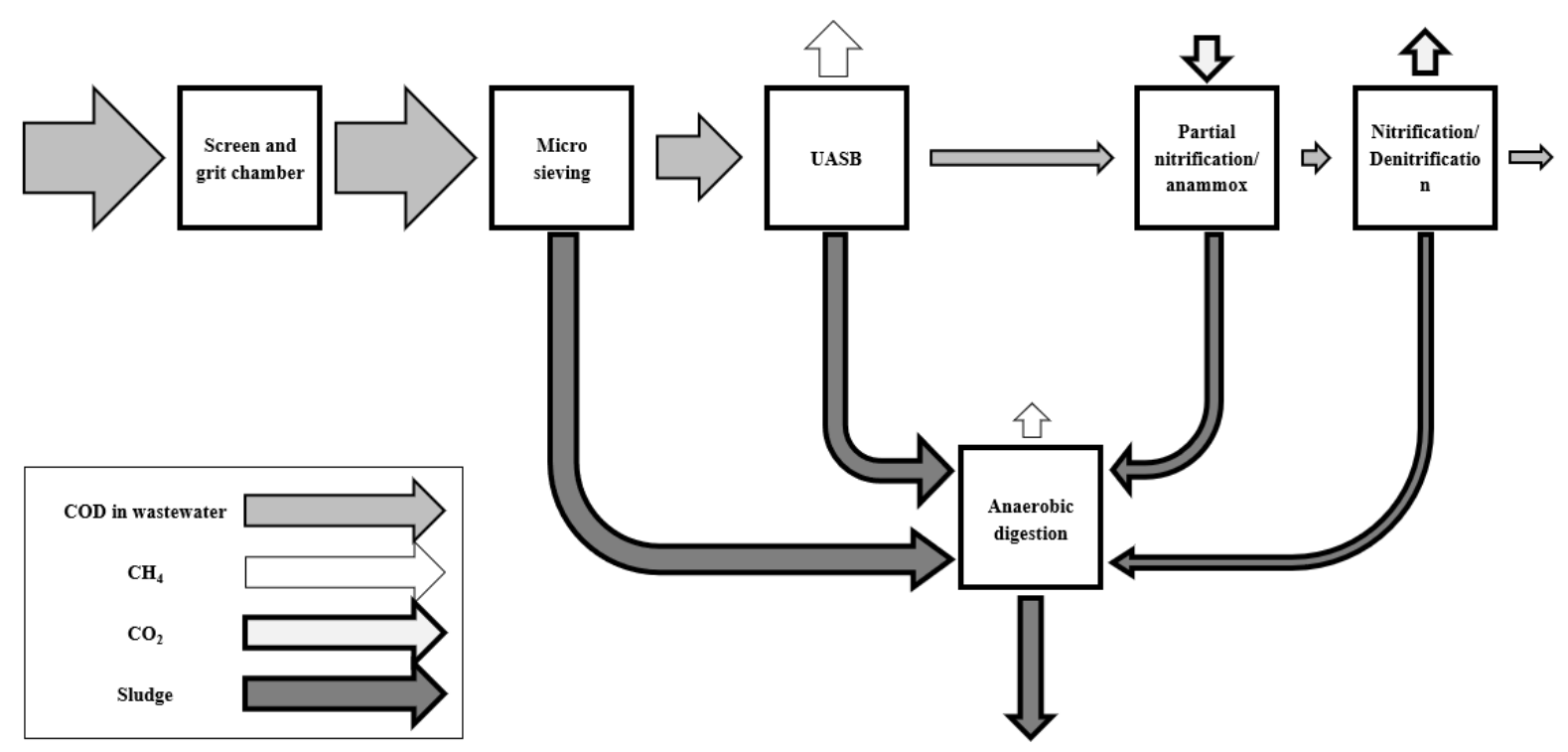


163 Figure 2 Scheme of wastewater treatment system B: UASB and anammox treatment production of UASB. Research by Cavalcanti et al. [94] yielded detailed empiric equations that can be used to predict the division of the influent COD over the effluent based on wastewater quality, sludge age, and temperature.

$$
\mathrm{mSeu}=\mathrm{fns}+0.27 \cdot \exp [-0.04 \cdot(\mathrm{Rsu}-4)] / 1.067^{\mathrm{T}-25}
$$

$$
\mathrm{mSxvu}=\mathrm{fnp}+\mathrm{fcv} \cdot \mathrm{Yan} \cdot(1-\mathrm{fns}-\mathrm{fnp})+0.25 \cdot \exp [(-0.04 \cdot(\mathrm{Rsu}
$$

$$
-4)] / 1.067^{\mathrm{T}-25}
$$

$$
\mathrm{mSdu}=1-\mathrm{mSeu}-\mathrm{mSxvu}
$$

177 where:

$178 \mathrm{mSeu}=$ fraction of influent COD ending up as non-settleable COD in the UASB

179 effluent (g COD/g COD)

$180 \mathrm{mSxvu}=$ influent COD fraction converted into anaerobic excess sludge $(\mathrm{g} \mathrm{COD} / \mathrm{g}$

181 COD)

$182 \mathrm{mSdu}=$ fraction of influent COD digested in UASB $(\mathrm{g} \mathrm{COD} / \mathrm{g}$ COD$)$

$183 \mathrm{~T}=$ temperature $=25^{\circ} \mathrm{C}$

184 fns = non-biodegradable, soluble influent COD fraction $(\mathrm{g} \mathrm{COD} / \mathrm{g} \mathrm{COD})$

185 fnp $=$ non-biodegradable particulate influent COD fraction $(\mathrm{g} \mathrm{COD} / \mathrm{g}$ COD $)$

$186 \mathrm{Rsu}=$ anaerobic sludge age in the UASB reactor 
Yan = yield coefficient in an anaerobic environment (0.05 g VSS/g COD) as determined by Cavalcanti et al. [94]

Since the sludge age of UASB is greater than 20 to 40 days [76], sludge age is assumed to be $40 \mathrm{~d}$. Since biodegradable COD in wastewater could be converted into

$191 \mathrm{CH}_{4}$ at 15 and $35^{\circ} \mathrm{C}$ [64], operating temperature of treatment system was assumed to be $19225^{\circ} \mathrm{C}$. Energy production of UASB $(\mathrm{kWh} / \mathrm{d})=(\mathrm{mSdu})\left(\mathrm{Q}_{\mathrm{UASB}}\right)\left(\mathrm{S}_{\mathrm{UASB}}\right)\left(0.25 \mathrm{~g} \mathrm{CH}_{4} / \mathrm{g} \mathrm{COD}\right)$

$$
\left(10^{-3} \mathrm{~kg} / \mathrm{g}\right)\left(13.9 \mathrm{kWh} / \mathrm{kg} \mathrm{CH}_{4}\right)(38 \%)
$$

$$
=\frac{\text { Energy production of UASB }(\mathrm{kWh} / \mathrm{d})}{\text { COD removal in UASB }(\mathrm{kg} / \mathrm{d})}
$$

199 where:

$200 \mathrm{mSdu}=$ fraction of influent COD digested in UASB (g COD/g COD)

$201 \mathrm{~S}_{\mathrm{UASB}}=$ Influent COD concentration to UASB $\left(\mathrm{g} / \mathrm{m}^{3}\right)$

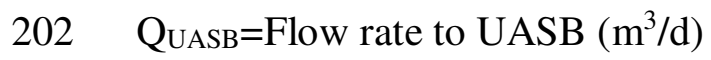

203 COD removal in UASB $(\mathrm{kg} / \mathrm{d})=\mathrm{COD}$ digested in UASB+COD discharged as sludge 204 Qasim and Zhu [95] reported that $1 \mathrm{~kg}$ COD could be converted to $0.25 \mathrm{~kg} \mathrm{CH}_{4}$ by 205 UASB. It was assumed that UASB combining the heat and power (CHP) technologies 206 could convert $38 \%$ of $\mathrm{CH}_{4}$ formed in the anaerobic digestion to electricity with an 207 energy density of approximately $13.9 \mathrm{kWh} / \mathrm{kg} \mathrm{CH}$ [77].

$$
\mathrm{RT}_{\mathrm{AD}}=15 \mathrm{~d}
$$

$$
\mathrm{T}_{\mathrm{AD}}=35^{\circ} \mathrm{C}
$$


214 where:

$215 \mathrm{RT}_{\mathrm{AD}}=$ sludge retention time in the high-rate digester $(\mathrm{d})$

$216 \mathrm{~T}_{\mathrm{AD}}=$ operation temperature $\left({ }^{\circ} \mathrm{C}\right)$ in the high-rate digester

$217 \prod_{\mathrm{AD}}=$ biodegradable COD destruction value

218 Since combined heat and power (CHP) could convert the $\mathrm{CH}_{4}$ formed in anaerobic 219 digestion to heat to run an anaerobic digester at high temperature, operation temperature 220 is assumed to be $35{ }^{\circ} \mathrm{C}$ in the anaerobic digester. Side stream high-rate anaerobic 221 digester converted sludge to $\mathrm{CH}_{4}$ in the absence of air at a specific solids retention time 222 and a specific temperature. Mean values of solids retention time and temperature shall 223 be between 15 days at $35^{\circ} \mathrm{C}$ to $55^{\circ} \mathrm{C}$ and 60 days at $20^{\circ} \mathrm{C}$ [96]. Kabouris et al. reported 224 that the biodegradable volatile solids destruction value of anaerobic digester was $69 \%$ 225 at a retention time of 12 days and $35^{\circ} \mathrm{C}$ [97]. It was reported $70 \%$ of biodegradable $226 \mathrm{COD}$ could be converted to $\mathrm{CH}_{4}$ at $35^{\circ} \mathrm{C}$ [77]. As a result, retention time, temperature 227 and biodegradable COD destruction value of the high-rate digester are assumed to be $228 \quad 15 \mathrm{~d}, 35^{\circ} \mathrm{C}$ and $70 \%$. biomass 


$$
=1.32 \mathrm{kWh} / \mathrm{kg} \mathrm{NH}_{4-} \mathrm{N}
$$

240 where:

$241 \mathrm{OT}_{\mathrm{a}}=$ Oxygen transfer efficiency (actual) $=1.2 \mathrm{~kg} \mathrm{O}_{2} / \mathrm{kWh} \mathrm{[76]}$

242 Since biodegradable COD in wastewater could be converted into $\mathrm{CH}_{4}$ at 15 and $24335^{\circ} \mathrm{C}[64]$, the operating temperature of the treatment system was assumed to be $25^{\circ} \mathrm{C}$.

244 Therefore, energy consumption is estimated based on $\mathrm{O}_{2}$ mass demand and oxygen 245 transfer efficiency at $25^{\circ} \mathrm{C}[76]$. production $[76,77]$ :

$$
\text { Unit electricity consumption }\left(\mathrm{kWh} / \mathrm{m}^{3}\right)
$$

$$
=\frac{\text { Aeration demand of PN } / \mathrm{A} \text { and } \mathrm{NDN}\left(\mathrm{kgO}_{2} / \mathrm{d}\right)}{\text { Oxygen transfer efficiency (actual)Q }}
$$

Unit electricity consumption( $\left.\mathrm{kWh} / \mathrm{kg} \mathrm{N} \mathrm{N}_{\text {removed }}\right)$

$$
=\frac{\text { Aeration demand of PN } / \mathrm{A} \text { and } \mathrm{NDN}\left(\mathrm{kgO}_{2} / \mathrm{d}\right)}{\text { Oxygen transfer efficiency (actual) }(\mathrm{N} \text { removal }(\mathrm{kg} / \mathrm{d}))}
$$

254 where $\mathrm{Q}=$ flow rate $\left(\mathrm{m}^{3} / \mathrm{d}\right)$

$$
\text { Oxygen transfer efficiency (actual) }=1.2 \mathrm{~kg} \mathrm{O}_{2} / \mathrm{kWh}
$$


262 Unit energy production $\left(\mathrm{kWh} / \mathrm{kg}\right.$ BOD $\left._{\text {removed }}\right)=\frac{\text { Electricity production }(\mathrm{kWh} / \mathrm{d})}{\text { BOD removal }(\mathrm{kg} / \mathrm{d})}$

264 It was assumed that UASB combining the heat and power (CHP) technologies could 265 convert $38 \%$ of $\mathrm{CH}_{4}$ formed in the mainstream and the side stream anaerobic digestion 266 to electricity with an energy density of approximately $13.9 \mathrm{kWh} / \mathrm{kg} \mathrm{CH}_{4}$ [77]. The 267 energy demand of a WWTP mainly includes power consumption of the wastewater lift 268 pump, aeration equipment, and sludge treatment. The energy consumption of 269 biological treatment accounts for $50-70 \%$ of the overall energy consumption [98]. 270 Since UASB removes COD without consuming oxygen, aeration energy of PN/A, and 271 NDN process was the dominant energy demand. Biodegradable COD in wastewater 272 could be converted into $\mathrm{CH}_{4}$ at 15 and $35^{\circ} \mathrm{C}$ [64], the operating temperature of the 273 treatment system was assumed to be $25^{\circ} \mathrm{C}$. Therefore, energy consumption is estimated 274 based on $\mathrm{O}_{2}$ mass demand and oxygen transfer efficiency at $25^{\circ} \mathrm{C}$ [76].

\section{$275 \quad 2.2 .4 \quad$ Environmental indicators}

276 Many studies selected global warming and eutrophication potential to assess the 277 environmental performance of wastewater treatment systems [99-101]. In the current 278 study, the effluent wastewater quality, energy consumption and energy production were converted to environmental indicators per volume of treated wastewater based on table

2. These two environmental indicators were selected to evaluate the impact of different 281 industrial wastewaters on environmental sustainability metrics of the innovative 282 treatment technologies.

283 Table 2 Effluent wastewater quality, energy, and corresponding environmental indicators 


\begin{tabular}{|c|c|c|c|}
\hline Parameter & $\begin{array}{c}\text { Global warming potential } \\
\left(\mathrm{kg} \mathrm{CO} \mathrm{CO}_{2} \mathrm{eq} / \mathrm{m}^{3}\right)\end{array}$ & $\begin{array}{l}\text { Eutrophication potential } \\
\left(\mathrm{kg} \mathrm{PO}_{4}{ }^{3-} \mathrm{eq}^{\left.-\mathbf{m}^{3}\right)}\right.\end{array}$ & Reference \\
\hline Effluent COD $\left(\mathrm{kg} / \mathrm{m}^{3}\right)$ & & 0.022 & \multirow{4}{*}{ [101] } \\
\hline Effluent nitrogen $\left(\mathrm{kg} / \mathrm{m}^{3}\right)$ & & 0.402 & \\
\hline Energy consumption $\left(\mathrm{kWh} / \mathrm{m}^{3}\right)$ & 0.591 & 0.00115 & \\
\hline Energy production $\left(\mathrm{kWh} / \mathrm{m}^{3}\right)$ & -0.591 & -0.00115 & \\
\hline
\end{tabular}

\subsubsection{Unit cost of WWTP}

287 The following equations are used in calculating the unit capital cost and unit 288 operation and maintenance $(\mathrm{O} \& \mathrm{M}) \operatorname{cost}[76]$ :

289 Annualized capital cost $(\$ / y r)=$ Capital $\operatorname{cost}(\$) \times$ Capital Recovery Factor (CRF)

$$
\mathrm{CRF}=\frac{1}{\text { annualization factor }}=\frac{1}{\mathrm{a}_{\mathrm{i}, \mathrm{n}}}=\frac{\mathrm{i}(1+\mathrm{i})^{\mathrm{n}}}{(1+\mathrm{i})^{\mathrm{n}}-1}
$$

291 where $\mathrm{i}=$ interest rate $($ annual $)=6 \%$

$$
\text { Unit capital } \operatorname{cost}\left(\$ / \mathrm{m}^{3}\right)=\frac{\text { Annualized capital cost }(\$ / \mathrm{yr})}{(\mathrm{Q})(365 \mathrm{~d} / \mathrm{yr})}
$$

$$
\text { Unit O\&M } \operatorname{cost}\left(\left(\$ / \mathrm{m}^{3}\right)=\frac{\text { Annual O\&M cost }(\$ / \mathrm{yr})}{(\mathrm{Q})(365 \mathrm{~d} / \mathrm{yr})}\right.
$$

$$
\text { Unit } \operatorname{cost}\left(\$ / \mathrm{m}^{3}\right)=\text { Unit capital } \operatorname{cost}\left(\$ / \mathrm{m}^{3}\right)+\text { Unit O\&M } \operatorname{cost}\left(\left(\$ / \mathrm{m}^{3}\right)\right.
$$

$$
=\frac{\text { Annualized capital cost }(\$ / \mathrm{yr})}{(\text { COD removal }(\mathrm{kg} / \mathrm{d}))(365 \mathrm{~d} / \mathrm{yr})}
$$

$$
+\frac{\text { Annual O\&M cost }(\$ / y r)}{(\text { COD removal }(\mathrm{kg} / \mathrm{d}))(365 \mathrm{~d} / \mathrm{yr})}
$$


306 To compare the cost of treatment systems, the total capital costs (\$) were annualized

307 over the expected lifetime of a WWTP. Economic lifetime and interest rate were 308 assumed to be 20 years and 6\% [76]. Capital costs (\$) were annualized capital costs $309(\$ / y r)$ based on the interest rate and lifetime. The total unit cost was calculated as the 310 summation of the unit capital and the unit O\&M costs.

\section{Results and Discussions}

\subsection{Impact of different industrial wastewater quality}

314 Pollutant concentration and flow rate determine the mass of the contaminants removed, whereas the performance of wastewater treatment equipment depends on 316 characteristics of wastewater such as particulate matter fraction and biodegradability.

317 TSS/COD ratio and BOD/COD ratio are widely used as indicators of these two different 318 types of wastewater characteristics. Figure 3 compares these indicators of different 319 industrial wastewater. It shows that the TSS/COD ratio of textile wastewater is higher 320 than those of other industrial wastewaters. Due to relatively high TSS concentration, 321 micro sieving shows TSS removal of greater than 50\% and significantly higher COD 322 removal than the primary clarifier, as shown in Figure 4. For tannery wastewater, meat 323 processing wastewater, and textile wastewater, the average COD removal by micro 324 sieving is $35.36 \%, 39.08 \%$, and $32.50 \%$, respectively, which are higher than that by 325 primary clarifier. Textile wastewater has a relatively lower TSS concentration than 326 other industrial wastewaters in Table 1. However, primary clarifier in textile 327 wastewater treatment shows higher COD removal than tannery wastewaters due to the 328 high TSS/COD ratio of textile wastewater, as shown in Figure 4. To assess the 329 influence of wastewater quality on COD removal of the primary clarifier and micro 
330 sieving, Pearson correlation analysis was carried out to evaluate the correlation between

331 COD removal and related parameters at a level of significance of $\mathrm{p}<0.01$.

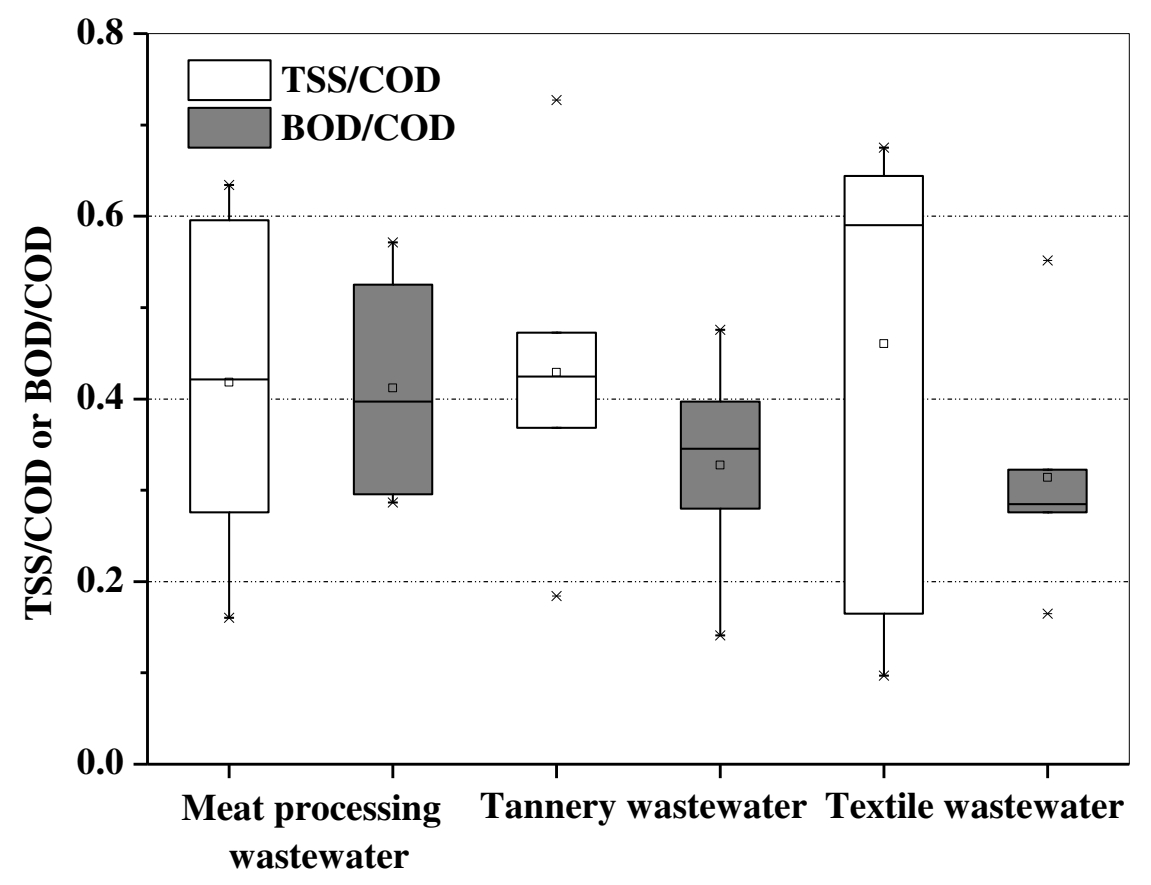

333 Figure 3 TSS/COD ratio and BOD/COD ratio for different industrial wastewater

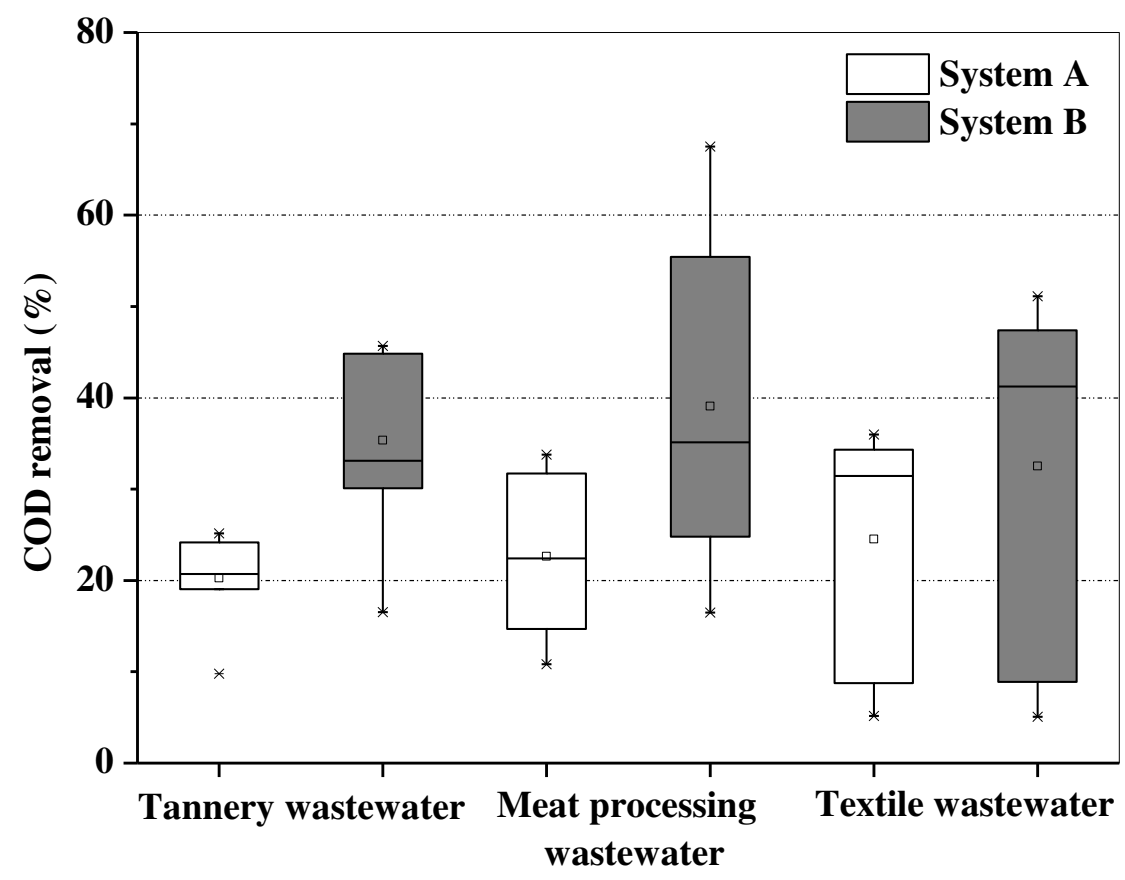


335 Figure 4 COD removal of primary treatment for different industrial wastewater

336 Table 3 shows the Pearson's correlations between COD removal of two systems,

337 the concentration of TSS and TSS/COD. Compared with TSS concentration, the ratio

338 between TSS and COD showed stronger positive correlations with COD removal at the

3390.01 level. Therefore, regression models of COD removal are developed based on

340 TSS/COD ratio. The trend lines for predicting COD removal of primary treatment from

341 TSS/COD are depicted in Figure 5. TSS concentration of textile wastewater is lower

342 than those of other industrial wastewaters. However, textile wastewater has a relatively

343 low concentration of COD, as shown in Table 1. The particulate COD fraction of textile

344 wastewater is higher than those of other industrial wastewaters. Since TSS/COD ratio

345 is associated with particulate COD fraction, COD removal of two systems rises with

346 the increasing TSS/COD ratio of influent wastewater as shown in Figure 5. Therefore,

347 TSS/COD ratio is the key parameter for determining COD removal of primary

348 treatment. Due to the high particulate matter fraction, primary treatment shows

349 excellent separation performance during treatment of textile wastewater.

350 Table 3 Correlations between COD removal, TSS concentration, and TSS/COD ratio

of influent wastewater

\begin{tabular}{|c|c|c|}
\hline Pearson Correlation & COD removal of system A $(\boldsymbol{\%})$ & COD removal of system B (\%) \\
\hline TSS (mg/L) & 0.278 & $0.595^{* *}$ \\
\hline TSS/COD $(\%)$ & $0.941^{* *}$ & $0.910^{* *}$ \\
\hline
\end{tabular}

352

$353 * *$ At the 0.01 level (2-tailed), correlation is significant. 


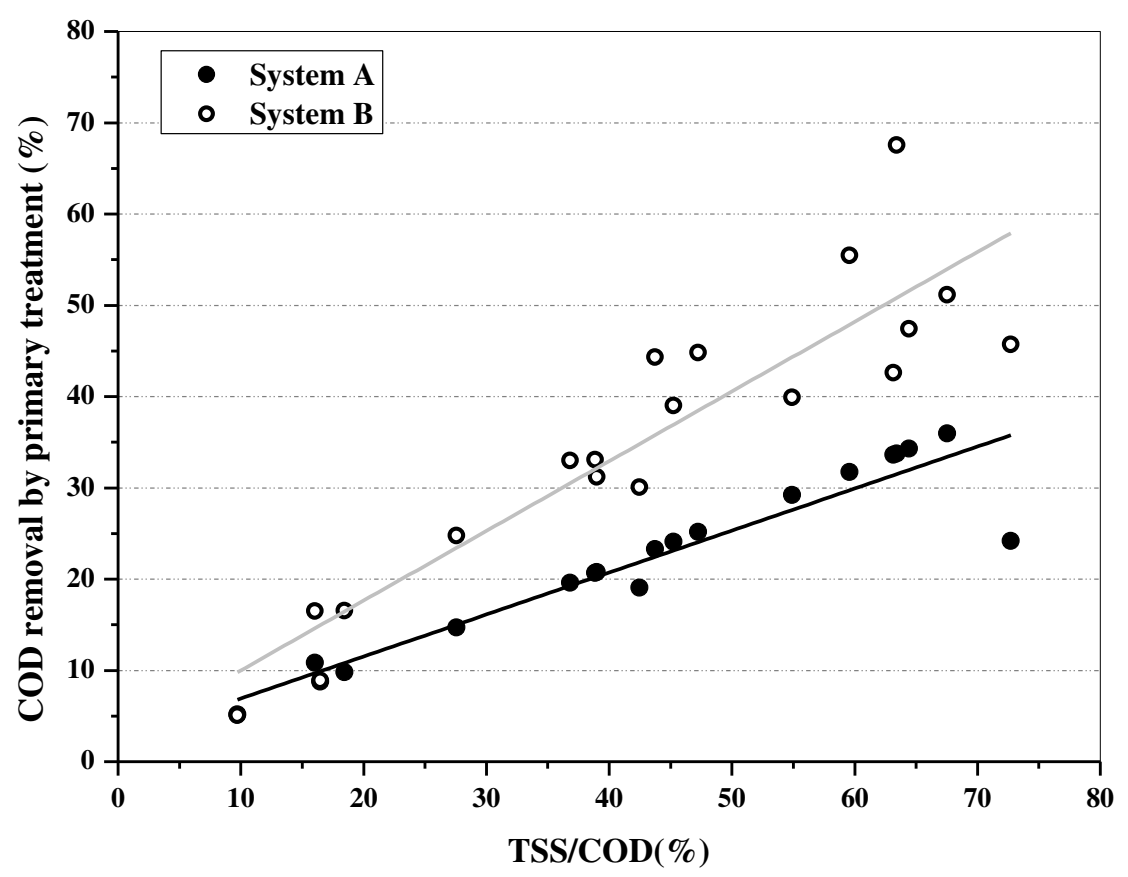

Figure 5 Variation of COD removal in primary treatment with TSS/COD ratio

356 Biodegradability expressed as the BOD/COD ratio represents the ability of a

357 substance to be removed by microorganisms. It is an common index of wastewater 358 biodegradation [102]. The higher the BOD/COD ratio, the higher is the 359 biodegradability. Biodegradability of meat processing wastewater, tannery wastewater, 360 and textile wastewater are shown in Figure 3 which illustrates the average BOD/COD 361 ratio of $0.412,0.327$, and 0.314 , respectively. Therefore, meat processing wastewater 362 has higher biodegradability than other industrial wastewaters. Figure 6 shows the $363 \mathrm{BOD} / \mathrm{COD}$ ratio of untreated wastewater and treated wastewater by primary clarifier 364 and micro-sieving. Biodegradability rises with the increasing BOD/COD ratio of 365 untreated wastewater. Figure 6 demonstrates that the slope of the linear fitting equation 366 for system B is greater than that of system A, which illustrates that micro-sieving could 367 improve the biodegradability of wastewater more significantly as compared with the 368 primary clarifier. Primary treatment increases the biodegradability of wastewater by 
reducing the particulate non-biodegradable COD fraction of industrial wastewater. As compared to system $\mathrm{A}$, the $\mathrm{BOD} / \mathrm{COD}$ ratio of wastewater increased by $0.59 \%-7.50 \%$,

$3710.60 \%-3.57 \%$, and $0.01 \%-2.19 \%$ for meat processing wastewater, tannery wastewater, 372 and textile wastewater, respectively. Due to the relatively low TSS concentration of 373 textile wastewater, TSS removal by primary clarifier and by micro sieving and variation 374 of BOD/COD ratio is smaller. Meat processing wastewater has higher biodegradability 375 and TSS concentration, micro sieving increases mean and maximum BOD/COD ratio 376 to 0.48 and 0.63 . Hence, the biodegradability of industrial wastewater with a high 377 concentration of TSS is easier to be improved by micro-sieving.

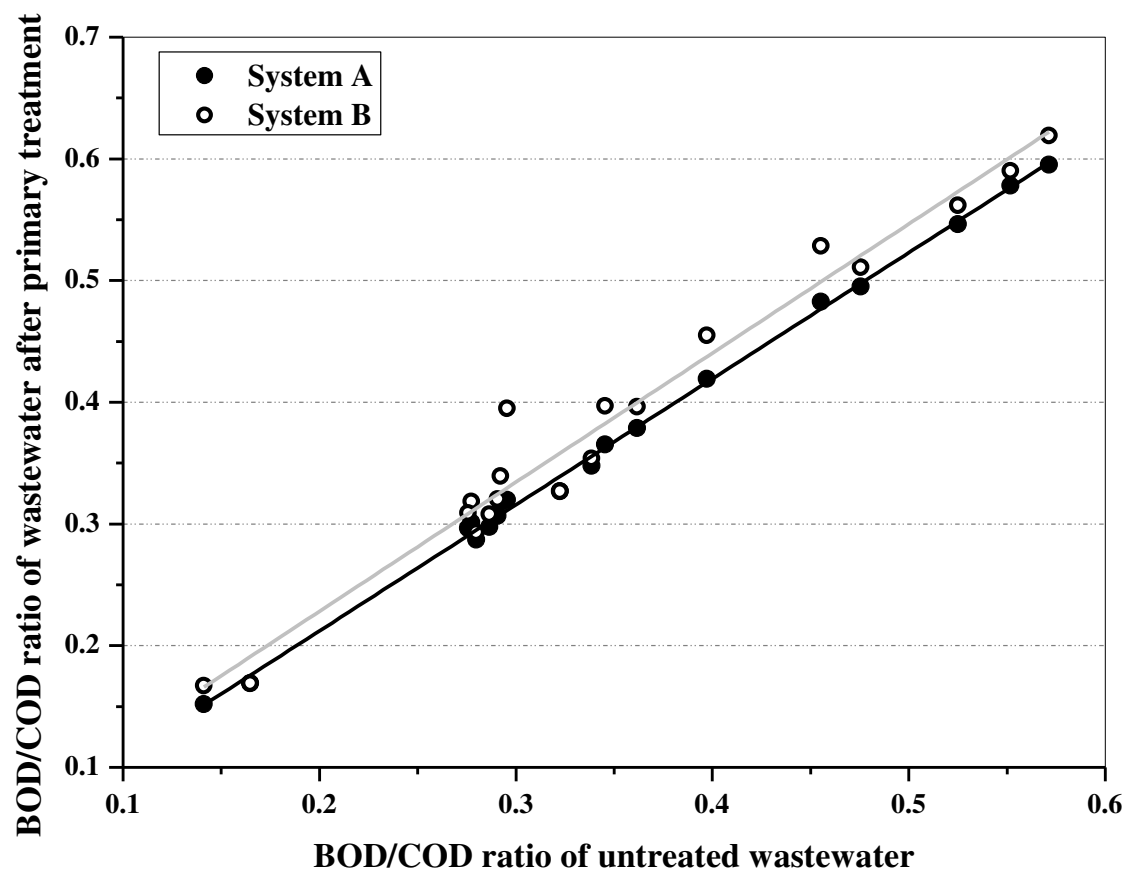
Figure 6 Variation of biodegradability after primary treatment removal of aerobic treatment in system B decreases by $40.7 \%-66.5 \%, 33.6-60.0 \%$, and 
wastewater as compared to aerobic treatment in system A in Figure 7. Micro-sieving and UASB could reduce oxygen demand for all kinds of industrial wastewater. In secondary treatment, the UASB reactor removes $15.8 \%-53.5 \%, 14.0 \%-49.0 \%$, and $22.9 \%-51.1 \%$ of COD for three kinds of industrial wastewater. Because of the higher $\mathrm{BOD} / \mathrm{COD}$ ratio of treated meat processing wastewater by micro-sieving, UASB could convert more COD to $\mathrm{CH}_{4}$ than other industrial wastewater, which resulted in less oxygen demand to remove the remaining COD.

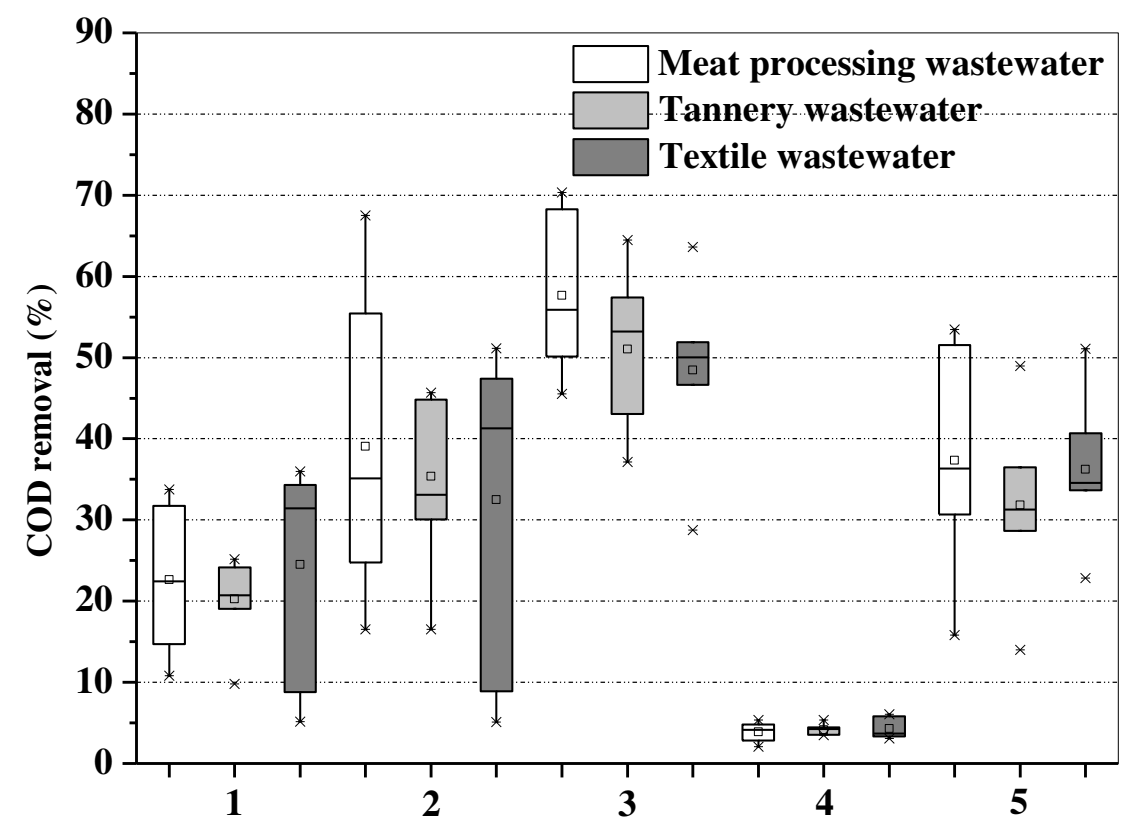

392 Figure 7 COD removal of primary and secondary treatment (1: Primary clarifier, 2:

393 Micro sieving, 3: Aerobic treatment in system A, 4: Aerobic treatment in system B, 5: recovery. Since the BOD/COD ratio of treated wastewater by primary treatment is 397 positively related to the influent wastewater quality as shown in Figure $6, \mathrm{CH}_{4}$ production/COD influent to secondary treatment (\%) rises with increasing 
400 the conversion of organic matter to biogas, COD removal of UASB reactor also shows 401 strong positive correlations with the BOD/COD ratio of raw wastewater, as shown in 402 Figure 8. This suggests that the biodegradability of wastewater could be used for 403 predicting methane conversion rate and COD removal of UASB reactor in the industrial 404 wastewater treatment system with micro sieving. In addition, UASB shows excellent 405 biogas production efficiency for treating industrial wastewater with high 406 biodegradability.

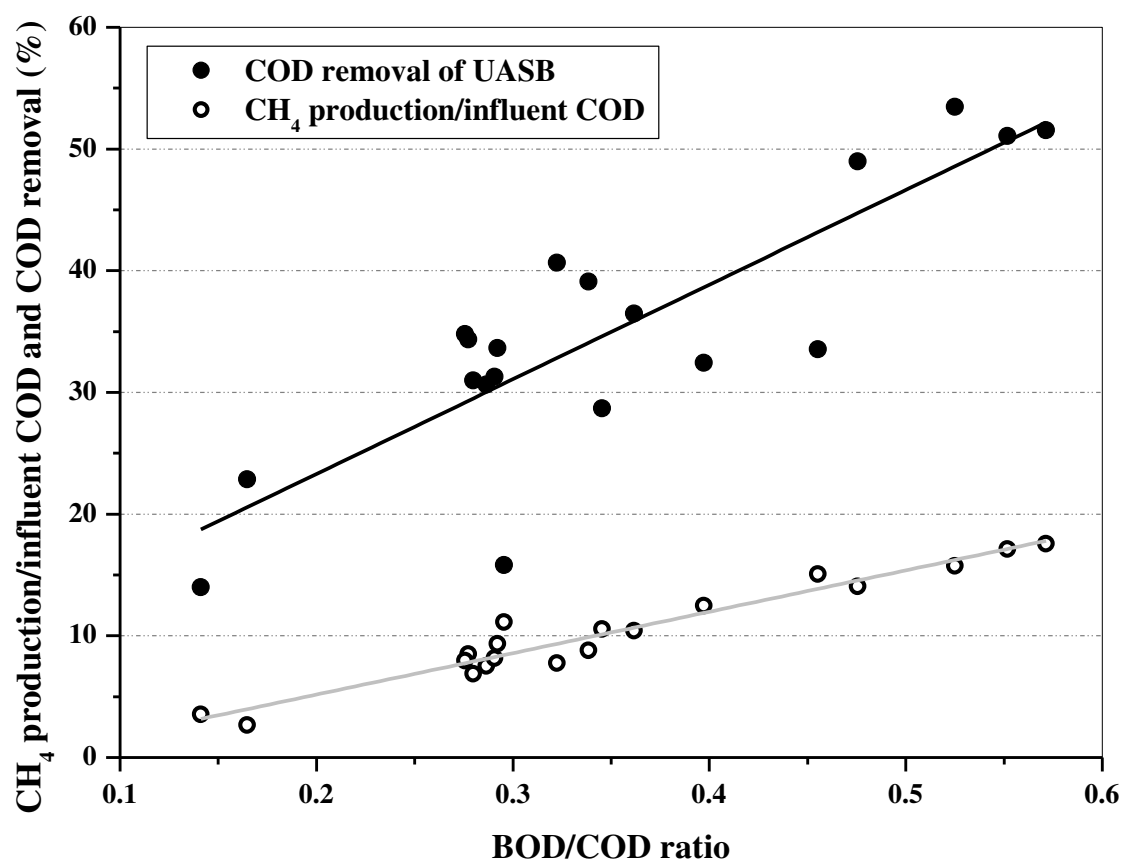

408 Figure $8 \mathrm{CH}_{4}$ production/influent COD to UASB and COD removal of UASB reactor

\subsection{Effluent wastewater quality}

410 Since aerobic treatment in systems A and B is designed based on low effluent BOD 411 and COD concentration, two treatment systems could achieve similar COD removal 412 and concentration in the effluent, as shown in Figures 7 and 9. Table 4 shows current 413 discharge standards of organics in industrial wastewater in different countries, 
414 including European [103], the USA [11], China [104, 105], and India [106-108]. In 415 figure 9, effluent COD concentration are 116.61-1683.80, 356.13-2952.27 and 14.19$416680.48 \mathrm{mg} / \mathrm{L}$, respectively. Most of the effluent wastewater quality in the two systems 417 does not meet the current discharge standards. This is due to a much high concentration 418 of COD, relatively low biodegradability (BOD/COD ratio), and the relatively high 419 content of refractory soluble organic matter. Most of the remaining COD, which is the 420 soluble non-biodegradable matter, is not easily removed by primary physical treatment 421 and biological processes. Physical-chemical treatment such as adsorption might be 422 required to remove soluble substances by the accumulation of those substances on 423 activated carbon to increase COD removal efficiency and meet the discharge 424 requirement. Figure 9 illustrates that the effluent of some meat processing wastewater 425 and textile wastewater achieve the discharge requirement of several countries due to 426 their low concentration of COD and relatively high BOD/COD ratio. Therefore, it is 427 necessary to study the relationship between the total COD removal of primary treatment 428 and biological processes and wastewater quality. 


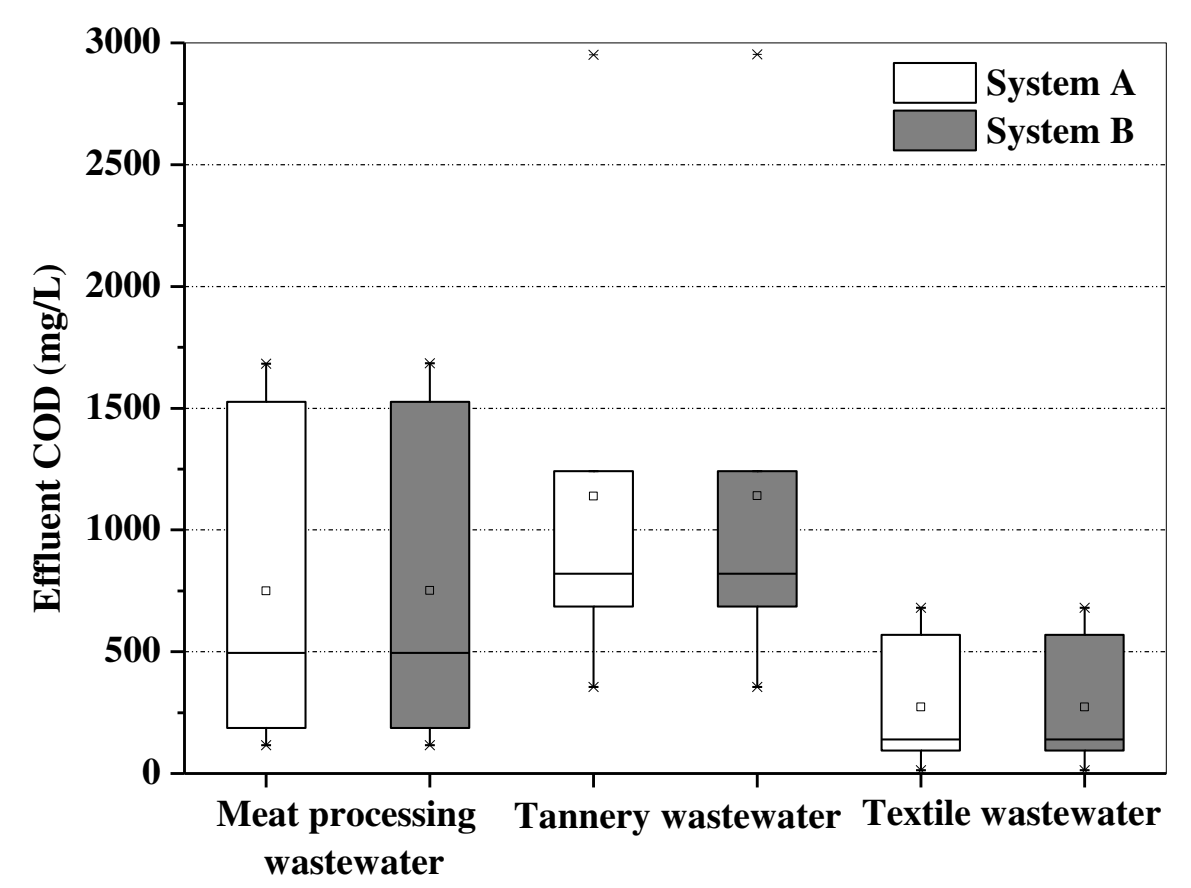

$430 \quad$ Figure 9 Effluent COD concentration of 3 industrial wastewater in two treatment systems

432 Table 4 Discharge standards of industrial wastewater in different countries

\begin{tabular}{|c|c|c|c|c|c|c|c|c|c|c|c|}
\hline \multirow{2}{*}{$\begin{array}{l}\text { Type of wastewater } \\
\text { Meat processing } \\
\text { wastewater }\end{array}$} & \multirow[b]{2}{*}{ Parameter } & \multicolumn{2}{|c|}{ EU } & \multicolumn{2}{|c|}{ USA } & \multicolumn{2}{|c|}{ Canada } & \multicolumn{2}{|c|}{ China } & \multicolumn{2}{|c|}{ India } \\
\hline & & $\begin{array}{c}\mathrm{Mi} \\
\mathrm{n}\end{array}$ & $\begin{array}{c}\text { Ma } \\
\text { x }\end{array}$ & $\begin{array}{c}\mathrm{Mi} \\
\mathrm{n}\end{array}$ & $\begin{array}{c}\mathrm{Ma} \\
\mathbf{x}\end{array}$ & $\begin{array}{c}\text { Mi } \\
\text { n }\end{array}$ & $\begin{array}{c}\mathrm{Ma} \\
\mathbf{x}\end{array}$ & $\begin{array}{c}\mathrm{Mi} \\
\mathrm{n}\end{array}$ & $\begin{array}{c}\text { Ma } \\
\mathbf{x} \\
\end{array}$ & $\begin{array}{c}\mathrm{Mi} \\
\mathrm{n}\end{array}$ & $\begin{array}{c}\text { Ma } \\
\mathbf{x} \\
\end{array}$ \\
\hline \multirow{2}{*}{$\begin{array}{l}\text { Meat processing } \\
\text { wastewater }\end{array}$} & $\begin{array}{c}\text { BOD } \\
(\mathrm{mg} / \mathrm{L})\end{array}$ & \multicolumn{2}{|c|}{25} & 16 & 26 & 5 & 30 & 20 & 100 & 30 & 100 \\
\hline & $\begin{array}{l}\text { COD } \\
(\mathrm{mg} / \mathrm{L})\end{array}$ & \multicolumn{2}{|c|}{125} & & & & & 100 & 300 & \multicolumn{2}{|c|}{250} \\
\hline \multirow{2}{*}{ Tannery wastewater } & $\begin{array}{c}\text { BOD } \\
(\mathrm{mg} / \mathrm{L})\end{array}$ & & & & & & & & & \multicolumn{2}{|c|}{30} \\
\hline & $\begin{array}{c}\mathrm{COD} \\
(\mathrm{mg} / \mathrm{L})\end{array}$ & & & & & & & & & \multicolumn{2}{|c|}{250} \\
\hline \multirow{2}{*}{ Textile wastewater } & $\begin{array}{c}\text { BOD } \\
(\mathrm{mg} / \mathrm{L})\end{array}$ & & & & & & & \multicolumn{2}{|c|}{25} & 80 & 250 \\
\hline & $\begin{array}{l}\mathrm{COD} \\
(\mathrm{mg} / \mathrm{L})\end{array}$ & & & & & & & \multicolumn{2}{|c|}{100} & 156 & 400 \\
\hline
\end{tabular}

434 Table 5 shows the Pearson's correlations between COD removal, BOD/COD ratio, 435 and TSS/COD ratio. The ratio between BOD/COD and the ratio between TSS and 436 COD showed strong positive correlations with COD removal at the 0.01 level. Since 437 the BOD/COD ratio and TSS/COD ratio affect COD removal of UASB and primary 
treatment, regression models of COD removal are developed based on BOD/COD ratio and TSS/COD ratio. The equation for predicting COD removal of primary treatment and biological processes from BOD/COD and TSS/COD can be depicted as the

441 following equation:

COD removal $(\%)=75.69(\mathrm{BOD} / \mathrm{COD}$ ratio $)+57.53(\mathrm{TSS} / \mathrm{COD}$

ratio) +23.15

$\mathrm{R}^{2}=0.929$

442

443 452

The squared correlation coefficient $\mathrm{R}^{2}$ represents that the BOD/COD ratio and TSS/COD ratio of influent wastewater can explain $92.9 \%$ of COD removal. The BOD/COD ratio and TSS/COD ratio are positively related to COD removal efficiency. Micro-sieving and UASB could achieve higher COD removal when treating industrial wastewater with higher particulate matter fraction and biodegradability. Effluent COD concentration could be calculated based on COD removal and influent COD concentration. Therefore, characteristics of wastewater could be used for predicting effluent COD concentration of industrial wastewater in a system with primary treatment and biological processes to determine if physical-chemical treatment is required.

51 Table 5 Correlations between COD removal, BOD/COD ratio and TSS/COD ratio of 2

\begin{tabular}{|c|c|c|}
\hline Pearson Correlation & COD removal (\%) \\
\hline $\mathrm{BOD} / \mathrm{COD}(\%)$ & $.712^{* *}$ \\
\hline $\mathrm{TSS} / \mathrm{COD}(\%)$ & $.804 * *$ \\
\hline
\end{tabular}

$453 * *$ At the 0.01 level (2-tailed), correlation is significant

$454 \quad 3.3$ Energy demand and production

$455 \quad$ 3.3.1 Theoretical and actual energy production of UASB 
457 removal and unit energy consumption of UASB, as shown in Table 6. Theoretical COD

458 removal, unit methane production, and unit energy production at $25{ }^{\circ} \mathrm{C}$ are $54 \%-88 \%$,

$459 \quad 0.15-0.30 \mathrm{~m}^{3} \mathrm{CH}_{4} / \mathrm{kg}$ COD removal, and 0.52-1.03 kWh/kg COD.

460 Table 6 Theoretical COD removal, unit methane production, and unit energy

461 production of UASB without primary treatment

\begin{tabular}{|c|c|c|c|c|c|c|}
\hline BOD/COD ratio & 0.57 & 0.46 & 0.29 & 0.53 & 0.34 & 0.30 \\
\hline COD concentration $(\mathrm{mg} / \mathrm{L})$ & 2100.00 & 2350.00 & 4221.00 & 1697.00 & 3900.00 & 5422.25 \\
\hline COD removal $(\%)$ & 88.08 & 85.45 & 53.85 & 82.66 & 54.56 & 79.01 \\
\hline Unit $\mathrm{CH}_{4}$ production $\left(\mathrm{m}^{3} \mathrm{CH}_{4} / \mathrm{kg} \mathrm{COD}\right.$ removal at $0^{\circ} \mathrm{C}$ and $\left.1 \mathrm{~atm}\right) *$ & 0.27 & 0.22 & 0.17 & 0.26 & 0.21 & 0.14 \\
\hline Unit $\mathrm{CH}_{4}$ production $\left(\mathrm{m}^{3} \mathrm{CH}_{4} / \mathrm{kg} \mathrm{COD}\right.$ removal at $25^{\circ} \mathrm{C}$ and $\left.1 \mathrm{~atm}\right)$ & 0.30 & 0.24 & 0.19 & 0.28 & 0.23 & 0.15 \\
\hline Unit energy consumption (kWh/kg COD removal) & 1.03 & 0.83 & 0.65 & 0.97 & 0.80 & 0.52 \\
\hline
\end{tabular}

$462 *$ The following reaction is used for converting COD digested in UASB to methane:

463

$$
\mathrm{CH}_{4}+2 \mathrm{O}_{2} \rightarrow \mathrm{CO}_{2}+2 \mathrm{H}_{2} \mathrm{O}
$$

$4641 \mathrm{~kg}$ COD digested could be converted to $0.25 \mathrm{~kg} \mathrm{CH}_{4}$ or $0.35 \mathrm{~m}^{3} \mathrm{CH}_{4}$ theoretically at $465 \quad 0^{\circ} \mathrm{C}$ and $1 \mathrm{~atm}[95]$

466 Table 7 lists the data of COD removal and methane production of UASB in treating 467 food processing wastewater. These data were collected from published peer-reviewed 468 papers [109-111]. Actual COD removal, unit methane production, and unit energy 469 production at $25^{\circ} \mathrm{C}$ are $43 \%-95 \%, 0.01-0.38 \mathrm{~m}^{3} \mathrm{CH}_{4} / \mathrm{kg}$ COD removal, and $0.03-1.30$ $470 \mathrm{kWh} / \mathrm{kg}$ COD. As shown in Table 6, 7, and Figure 10, theoretical energy productions 471 are close to the actual values, which indicates the validity of empiric equations used in 472 this study.

473 Table 7 Actual COD removal and unit methane production and unit energy production of UASB

\begin{tabular}{|c|c|c|c|c|c|c|c|c|c|c|c|c|}
\hline HRT (h) & $\mathbf{2 2}$ & $\mathbf{2 2}$ & $\mathbf{2 2}$ & $\mathbf{1 8}$ & $\mathbf{1 8}$ & $\mathbf{1 4}$ & $\mathbf{1 4}$ & $\begin{array}{c}\mathbf{7 .} \\
\mathbf{1}\end{array}$ & $\mathbf{6 . 8}$ & $\mathbf{6 . 7}$ & $\mathbf{4 . 1}$ & $\mathbf{2 . 3}$ \\
\hline SRT (d) & & & & & & & & $\begin{array}{c}60 \\
.3\end{array}$ & $\begin{array}{c}23 . \\
4\end{array}$ & 14 & $\begin{array}{c}14 . \\
4\end{array}$ & 3.3 \\
\hline Temperature $\left({ }^{\circ} \mathrm{C}\right)$ & 35 & 35 & 35 & 35 & 35 & 35 & 35 & 33 & 33 & 33 & 33 & 33 \\
\hline COD (mg/L) & 28 & 32 & 42 & 30 & 65 & 39 & 63 & 82 & 57 & 52 & 54 & 55 \\
& 00 & 00 & 00 & 00 & 00 & 00 & 30 & 01 & 19 & 56 & 95 & 14 \\
\hline COD removal (\%) & 83 & 84 & 89. & 82. & 90. & 78. & 85 & 78 & 73 & 77 & 83 & 68 \\
\hline
\end{tabular}




\begin{tabular}{|c|c|c|c|c|c|c|c|c|c|c|c|c|}
\hline L biogas/g COD removed & $\begin{array}{c}0 . \\
55 \\
5\end{array}$ & $\begin{array}{l}0 . \\
47\end{array}$ & $\begin{array}{l}0.4 \\
02\end{array}$ & $\begin{array}{c}0.4 \\
6\end{array}$ & $\begin{array}{l}0.1 \\
92\end{array}$ & 0.3 & $\begin{array}{c}0 . \\
15 \\
7\end{array}$ & & & & & \\
\hline $\begin{array}{c}\mathrm{L} \mathrm{CH}_{4} / \mathrm{kg} \mathrm{SCOD} \mathrm{removed} \mathrm{(at} 25^{\circ} \mathrm{C} \\
\text { and } 1 \mathrm{~atm})\end{array}$ & & & & & & & & $\begin{array}{c}21 \\
3\end{array}$ & $\begin{array}{c}25 \\
4\end{array}$ & $\begin{array}{c}28 \\
3\end{array}$ & $\begin{array}{c}20 \\
1\end{array}$ & $\begin{array}{c}19 \\
9\end{array}$ \\
\hline $\begin{array}{l}\text { Unit } \mathrm{CH}_{4} \text { production }(\mathrm{m} 3 \mathrm{CH} 4 / \mathrm{kg} \\
\left.\mathrm{COD} \text { removal at } 0^{\circ} \mathrm{C} \text { and } 1 \mathrm{~atm}\right) *\end{array}$ & $\begin{array}{l}0 . \\
34\end{array}$ & $\begin{array}{l}0 . \\
29\end{array}$ & $\begin{array}{c}0.2 \\
5\end{array}$ & $\begin{array}{c}0.2 \\
9\end{array}$ & $\begin{array}{c}0.1 \\
2\end{array}$ & $\begin{array}{c}0.1 \\
9\end{array}$ & $\begin{array}{c}0 . \\
1\end{array}$ & $\begin{array}{l}0 . \\
07\end{array}$ & $\begin{array}{c}0.1 \\
5\end{array}$ & $\begin{array}{c}0.2 \\
3\end{array}$ & $\begin{array}{c}0.1 \\
5\end{array}$ & $\begin{array}{c}0.1 \\
1\end{array}$ \\
\hline $\begin{array}{l}\text { Unit } \mathrm{CH}_{4} \text { production }(\mathrm{m} 3 \mathrm{CH} 4 / \mathrm{kg} \\
\left.\mathrm{COD} \text { removal at } 25^{\circ} \mathrm{C} \text { and } 1 \mathrm{~atm}\right)\end{array}$ & $\begin{array}{l}0 . \\
38\end{array}$ & $\begin{array}{l}0 . \\
32\end{array}$ & $\begin{array}{c}0.2 \\
7\end{array}$ & $\begin{array}{c}0.3 \\
1\end{array}$ & $\begin{array}{c}0.1 \\
3\end{array}$ & 0.2 & $\begin{array}{l}0 . \\
11\end{array}$ & $\begin{array}{l}0 . \\
08\end{array}$ & $\begin{array}{c}0.1 \\
7\end{array}$ & $\begin{array}{c}0.2 \\
5\end{array}$ & $\begin{array}{c}0.1 \\
6\end{array}$ & $\begin{array}{c}0.1 \\
2\end{array}$ \\
\hline $\begin{array}{l}\text { Unit energy consumption }(\mathrm{kWh} / \mathrm{kg} \\
\text { COD removal) }\end{array}$ & $\begin{array}{l}1 . \\
30\end{array}$ & $\begin{array}{l}1 . \\
10\end{array}$ & $\begin{array}{c}0.9 \\
4\end{array}$ & $\begin{array}{c}1.0 \\
8\end{array}$ & $\begin{array}{c}0.4 \\
5\end{array}$ & $\begin{array}{c}0.7 \\
0\end{array}$ & $\begin{array}{l}0 . \\
37 \\
\end{array}$ & $\begin{array}{l}0 . \\
27\end{array}$ & $\begin{array}{c}0.5 \\
8\end{array}$ & $\begin{array}{c}0.8 \\
5\end{array}$ & $\begin{array}{c}0.5 \\
6\end{array}$ & $\begin{array}{c}0.4 \\
1 \\
\end{array}$ \\
\hline Reference & & & & [109] & & & & & & [110] & & \\
\hline HRT (h) & 24 & 24 & 24 & 24 & 24 & 24 & 24 & 24 & 24 & 24 & 24 & 24 \\
\hline SRT (d) & & & & & & & & & & & & \\
\hline Temperature $\left({ }^{\circ} \mathrm{C}\right)$ & 36 & 36 & 36 & 36 & 36 & 36 & 36 & 36 & 36 & 36 & 36 & 36 \\
\hline COD (mg/L) & $\begin{array}{l}35 \\
00\end{array}$ & $\begin{array}{l}60 \\
00\end{array}$ & $\begin{array}{c}10 \\
00 \\
0\end{array}$ & $\begin{array}{c}20 \\
00 \\
0\end{array}$ & $\begin{array}{c}28 \\
00 \\
0\end{array}$ & $\begin{array}{c}32 \\
00 \\
0\end{array}$ & $\begin{array}{l}35 \\
00\end{array}$ & $\begin{array}{l}60 \\
00\end{array}$ & $\begin{array}{c}10 \\
00 \\
0\end{array}$ & $\begin{array}{c}20 \\
00 \\
0\end{array}$ & $\begin{array}{c}28 \\
00 \\
0\end{array}$ & $\begin{array}{c}32 \\
00 \\
0\end{array}$ \\
\hline COD removal (\%) & $\begin{array}{c}>9 \\
0\end{array}$ & $\begin{array}{c}>9 \\
0\end{array}$ & $\begin{array}{c}>9 \\
0\end{array}$ & 48 & 45 & 43 & $\begin{array}{c}>9 \\
0\end{array}$ & $\begin{array}{c}>9 \\
0\end{array}$ & $\begin{array}{c}>9 \\
0\end{array}$ & 95 & 72 & 68 \\
\hline $\begin{array}{l}\text { Specific methane production } \\
\left(\mathrm{LCH}_{4} / \mathrm{g} \text { COD added at } 36^{\circ} \mathrm{C}\right)\end{array}$ & $\begin{array}{l}0 . \\
21\end{array}$ & $\begin{array}{l}0 . \\
15\end{array}$ & $\begin{array}{c}0.1 \\
2\end{array}$ & $\begin{array}{c}0.0 \\
2\end{array}$ & $\begin{array}{c}0.0 \\
1\end{array}$ & $\begin{array}{l}0.0 \\
04\end{array}$ & $\begin{array}{l}0 . \\
28\end{array}$ & $\begin{array}{l}0 . \\
19\end{array}$ & $\begin{array}{c}0.1 \\
8\end{array}$ & $\begin{array}{c}0.2 \\
1\end{array}$ & $\begin{array}{c}0.0 \\
8\end{array}$ & $\begin{array}{c}0.0 \\
4\end{array}$ \\
\hline $\begin{array}{l}\text { Unit } \mathrm{CH}_{4} \text { production }\left(\mathrm{m}^{3} \mathrm{CH}_{4} / \mathrm{kg}\right. \\
\left.\mathrm{COD} \text { removal at } 0^{\circ} \mathrm{C} \text { and } 1 \mathrm{~atm}\right) *\end{array}$ & $\begin{array}{l}0 . \\
21\end{array}$ & $\begin{array}{l}0 . \\
15\end{array}$ & $\begin{array}{c}0.1 \\
2\end{array}$ & $\begin{array}{c}0.0 \\
4\end{array}$ & $\begin{array}{c}0.0 \\
2\end{array}$ & $\begin{array}{c}0.0 \\
1\end{array}$ & $\begin{array}{l}0 . \\
27\end{array}$ & $\begin{array}{l}0 . \\
19 \\
\end{array}$ & $\begin{array}{c}0.1 \\
8\end{array}$ & 0.2 & 0.1 & $\begin{array}{c}0.0 \\
5\end{array}$ \\
\hline $\begin{array}{l}\text { Unit } \mathrm{CH}_{4} \text { production }\left(\mathrm{m}^{3} \mathrm{CH}_{4} / \mathrm{kg}\right. \\
\left.\text { COD removal at } 25^{\circ} \mathrm{C} \text { and } 1 \mathrm{~atm}\right)\end{array}$ & $\begin{array}{l}0 . \\
23\end{array}$ & $\begin{array}{l}0 . \\
16\end{array}$ & $\begin{array}{c}0.1 \\
3\end{array}$ & $\begin{array}{c}0.0 \\
4\end{array}$ & $\begin{array}{c}0.0 \\
2\end{array}$ & $\begin{array}{c}0.0 \\
1\end{array}$ & $\begin{array}{l}0 . \\
3\end{array}$ & $\begin{array}{l}0 . \\
2\end{array}$ & $\begin{array}{c}0.1 \\
9\end{array}$ & $\begin{array}{c}0.2 \\
1\end{array}$ & $\begin{array}{c}0.1 \\
1\end{array}$ & $\begin{array}{c}0.0 \\
6\end{array}$ \\
\hline $\begin{array}{l}\text { Unit energy consumption }(\mathrm{kWh} / \mathrm{kg} \\
\text { COD removal) }\end{array}$ & $\begin{array}{l}0 . \\
78\end{array}$ & $\begin{array}{l}0 . \\
56\end{array}$ & $\begin{array}{c}0.4 \\
4\end{array}$ & $\begin{array}{c}0.1 \\
4\end{array}$ & $\begin{array}{c}0.0 \\
7\end{array}$ & $\begin{array}{c}0.0 \\
3\end{array}$ & $\begin{array}{l}1 . \\
04\end{array}$ & $\begin{array}{l}0 . \\
70\end{array}$ & $\begin{array}{c}0.6 \\
7\end{array}$ & $\begin{array}{c}0.7 \\
4\end{array}$ & $\begin{array}{c}0.3 \\
7\end{array}$ & $\begin{array}{c}0.2 \\
0\end{array}$ \\
\hline Reference & \multicolumn{12}{|c|}{ [111] } \\
\hline
\end{tabular}

* Unit $\mathrm{CH}_{4}$ production at the standard temperature and pressure (STP) is estimated

476 based on the assuming methane/biogas ratio of $70 \%$ [112], $0^{\circ} \mathrm{C}$, and $1 \mathrm{~atm}$.

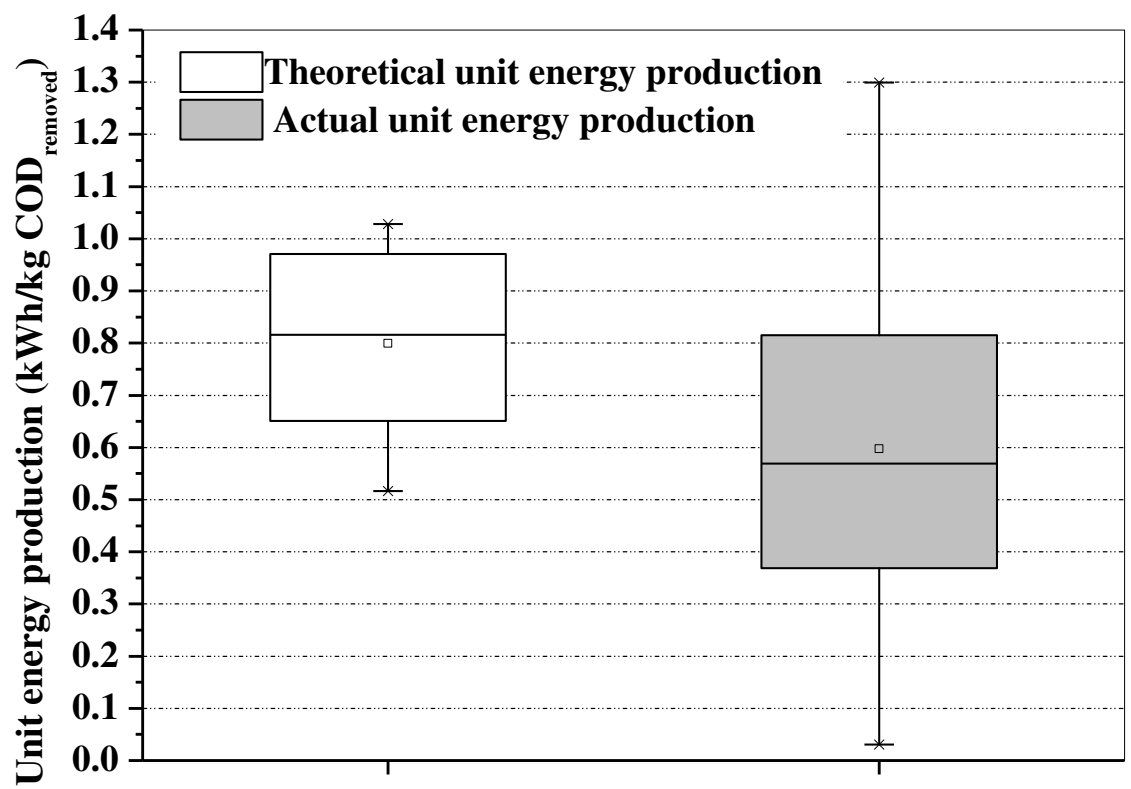

Food processing wastewater 
Figure 10 Actual and Theoretical unit energy production of UASB

481 removed. Based on equations (9-10), 1.32kWh/kg NH${ }_{4}^{+} \_\mathrm{N}$ was used as the theoretical 482 unit energy consumption of PN/A, which is close to the actual value, as shown in Figure 483 11. This proves the validity of the theoretical unit energy consumption. According to 484 the benchmarking method reported by Yang et al. [113], the mean actual unit energy 485 consumptions of $1.4 \mathrm{kWh} / \mathrm{kg} \mathrm{NH}_{4}{ }^{+}{ }_{-} \mathrm{N}$ could be selected as the benchmark data for 486 comparing with actual unit energy consumption to check the energy efficiency of PN/A 487 reactor.

Table 8 Energy consumption of PN/A reactors.

\begin{tabular}{|c|c|c|c|}
\hline Plant & Reactor type & Unit energy demand $\left(\mathbf{k W h} / \mathbf{k g} \mathbf{N H}_{\mathbf{4}}{ }^{+} \mathbf{N}\right.$ removed $)$ & Reference \\
\hline Apeldoorn & SBR & 1.1 & \\
\cline { 1 - 3 } Balingen & SBR & 0.92 & \multirow{2}{*}[114]{} \\
\hline Heidelberg & SBR & 1.67 & \\
\cline { 1 - 3 } Ingolstadt & SBR & 1.92 & \\
\hline Nieuwegein & SBR & 0.8 & \\
\hline Zurich & SBR & 1.11 & \\
\hline Olburgen & & 1.86 & \\
\cline { 1 - 3 } Malmö & MBBR & $1.45-1.75$ & \\
\hline
\end{tabular}




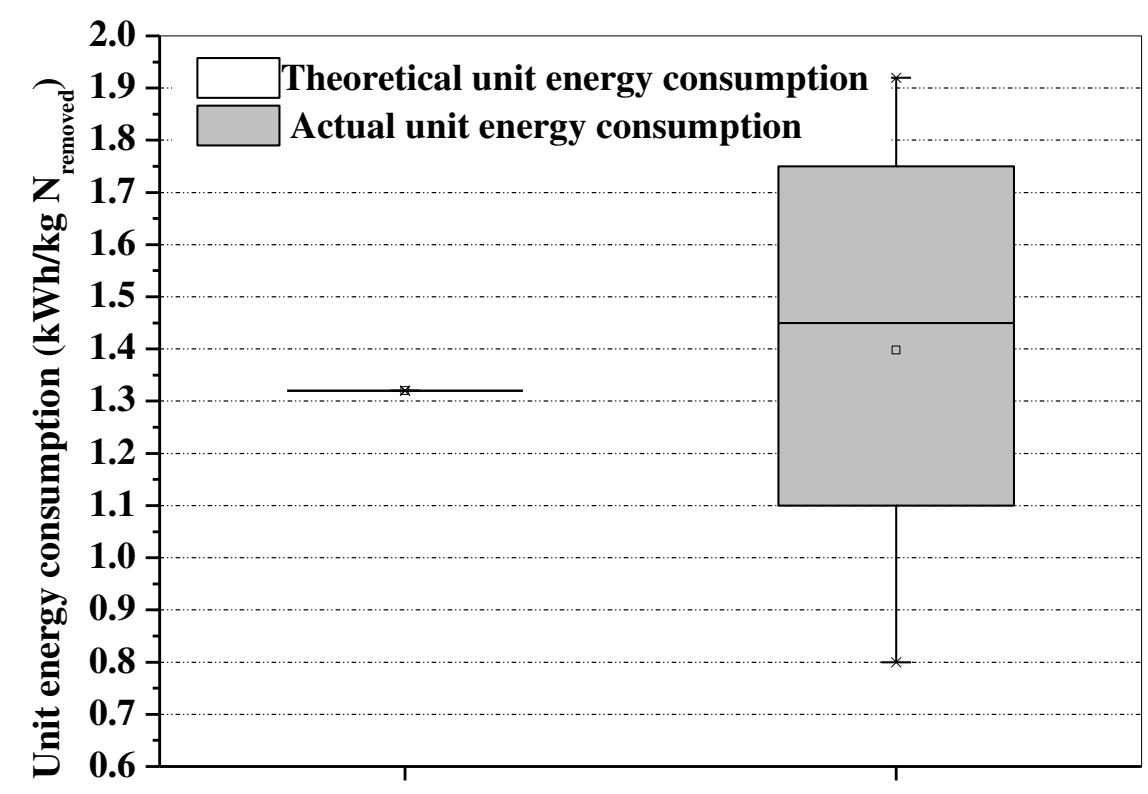

Food processing wastewater

490

Figure 11 Actual and Theoretical unit energy consumption of PN/A

\subsubsection{Energy consumption and production of WWTP}

Electricity consumption of a WWTP is mainly from the wastewater pump station, aeration equipment, and sludge treatment. Secondary biological treatment consumes $50-70 \%$ of the overall energy consumption of a WWTP [98]. Therefore, the energy required by aeration was the dominant energy consumption. Figure 12 shows that electricity consumption rises as the influent concentration of $\mathrm{NH}_{4}{ }_{-}{ }_{-} \mathrm{N}$ and soluble biodegradable organic nitrogen ( $\mathrm{sbON}$ ) increases. Therefore, unit energy consumption $(\mathrm{kWh} / \mathrm{kg} \mathrm{N}$ removal) is used for comparing energy efficiency of different industrial wastewater systems as shown in Figure 13. The oxygen requirement of PN/A process and nitrification process are 1.83 and $4.57 \mathrm{~g} \mathrm{O}_{2} / \mathrm{g} \mathrm{NH}_{4} \_\mathrm{N}$ converted. PN/A process in system B effectively reduces aeration consumption for removing $\mathrm{NH}_{4} \_\mathrm{N}$. Therefore, system B shows lower unit energy consumption than system A. In Figure 13, mean unit energy consumptions of system B for meat processing wastewater, tannery 
505 wastewater, and textile wastewater are $1.49,1.37$, and $1.39 \mathrm{kWh} / \mathrm{kg} \mathrm{N}$ removal, 506 respectively. Since primary treatment and UASB removes COD without using oxygen, 507 most of $\mathrm{O}_{2}$ is used for the PN/A process, especially in system B. Therefore, mean unit 508 energy consumptions of system B are close to than actual unit energy consumption of 509 PN/A, as shown in Figure 11.

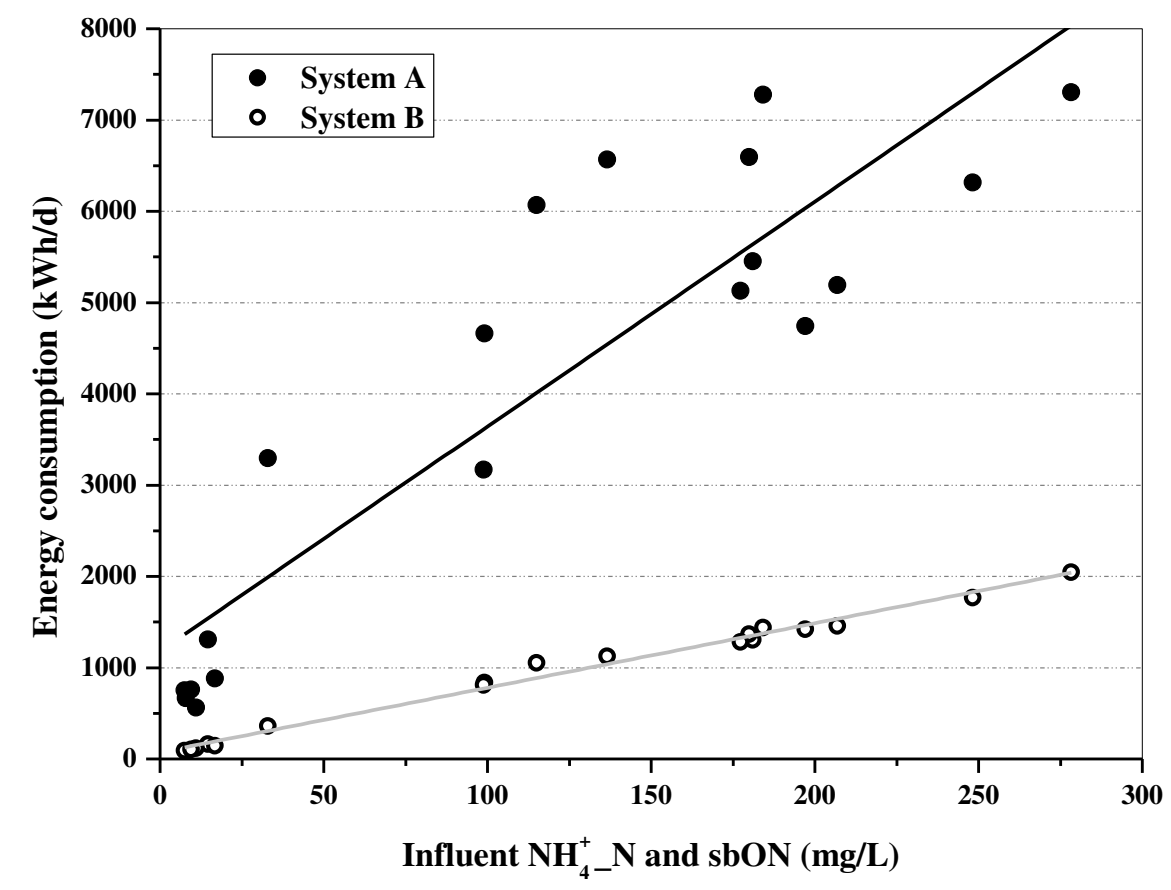

Figure 12 Electricity consumption and influent $\mathrm{NH}_{4}{ }^{+}{ }_{-} \mathrm{N}$ and sbON 


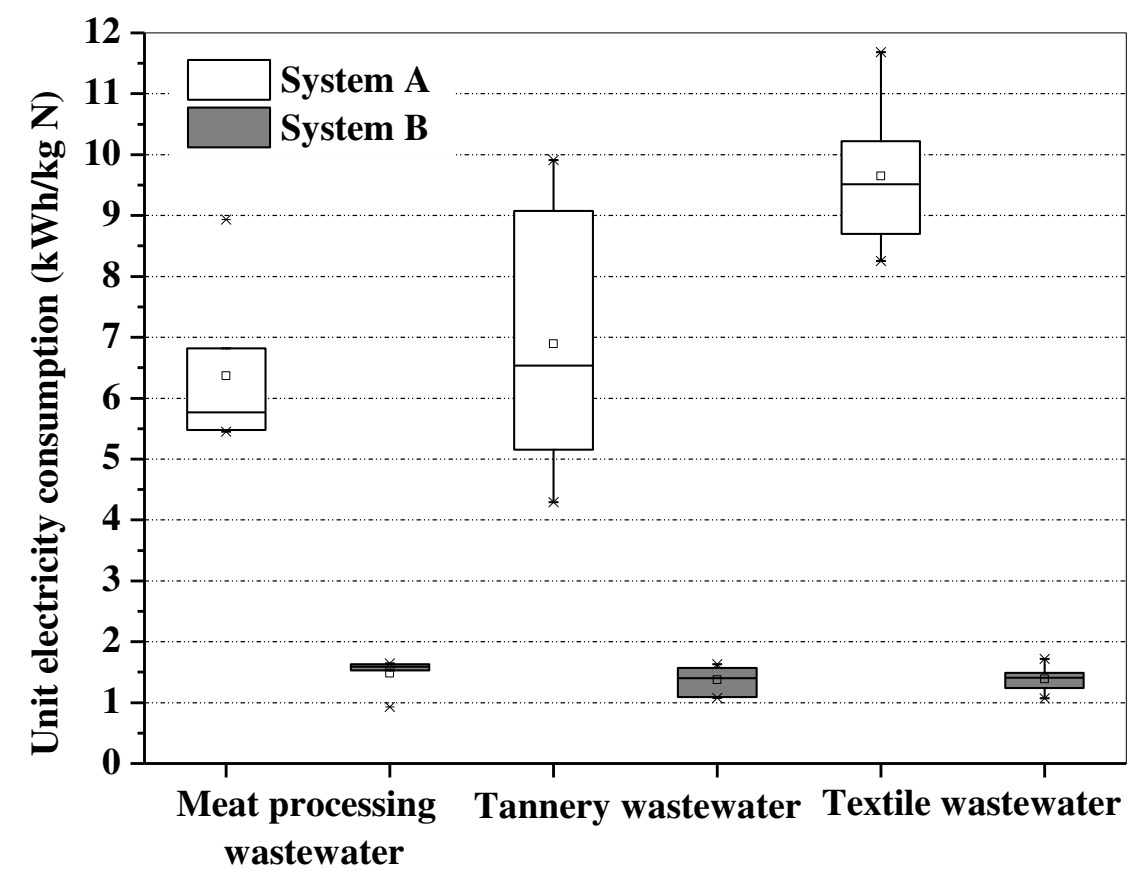

Figure 13 Unit electricity consumption

514 Except for BOD that is converted to $\mathrm{CO}_{2}$ in aerobic treatment, most of soluble BOD

515 (sBOD) in industrial wastewater and biodegradable particulate BOD (bpBOD) in 516 primary and secondary sludge are converted to $\mathrm{CH}_{4}$ to produce electricity and heat by 517 UASB and side stream anaerobic digester. Figure 14 illustrates energy production rises 518 with increasing influent BOD concentration. The unit energy production $(\mathrm{kWh} / \mathrm{kg}$ 519 BOD removal) is used as an indicator in assessing the influence of different industrial 520 wastewater on two treatment systems, as shown in Figure 15. The average unit energy 521 production of system B for meat processing wastewater, tannery wastewater, and textile 522 wastewater are $1.80,1.77$, and $1.73 \mathrm{kWh} / \mathrm{kg}$ BOD removal, respectively. The unit 523 energy production for food processing wastewater is higher than that of other industrial 524 wastewaters. Meat processing wastewater has higher BOD concentration and 525 biodegradability (BOD/COD ratio), as shown in Table 1 and Figure 3. This increases 526 biogas production efficiency and unit energy production of UASB reactors, as shown 
527 in Figure 16. In addition, sludge production from the PN/A process and denitrification 528 process increase $\mathrm{CH}_{4}$ production of side stream anaerobic digester. Therefore, the 529 energy positive system for treating meat processing wastewater could produce more 530 energy with the same BOD removal than that for treating tannery wastewater and textile 531 wastewater.

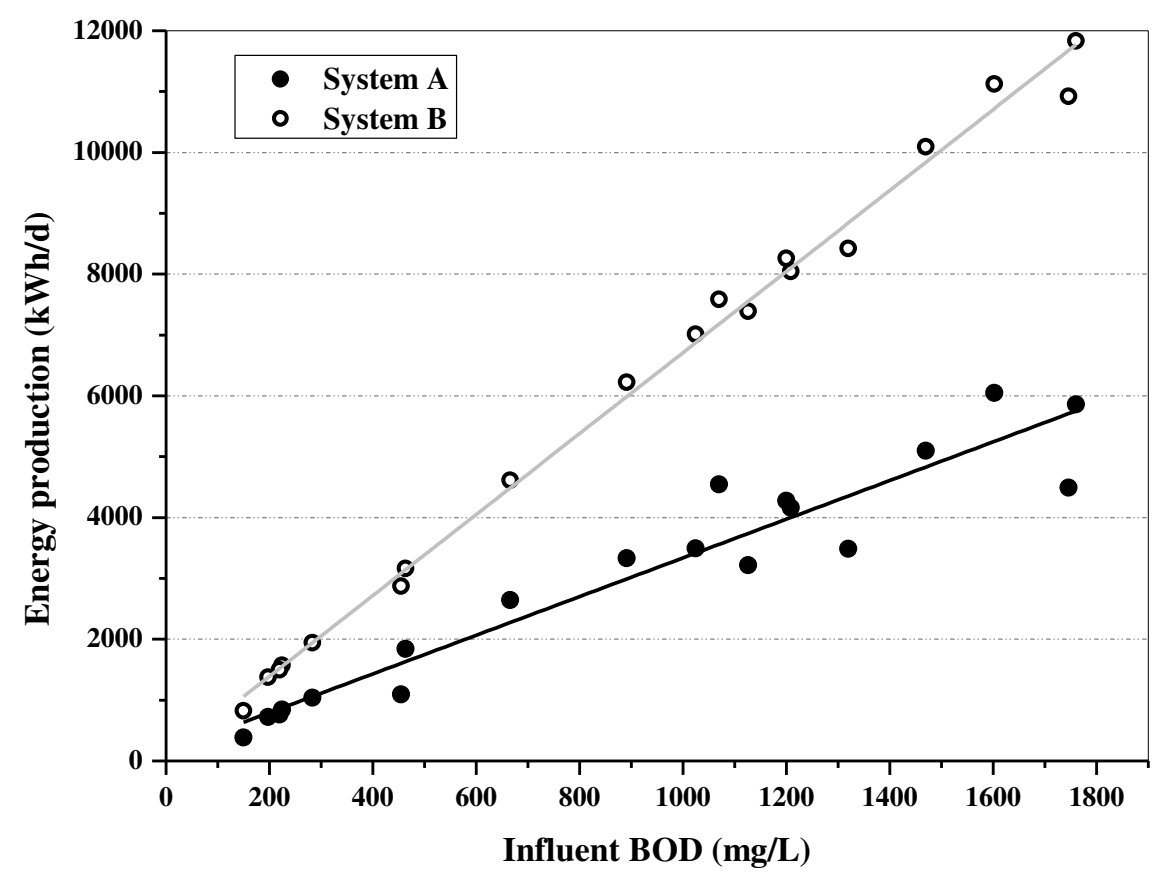

532 Figure 14 Electricity production and influent BOD 


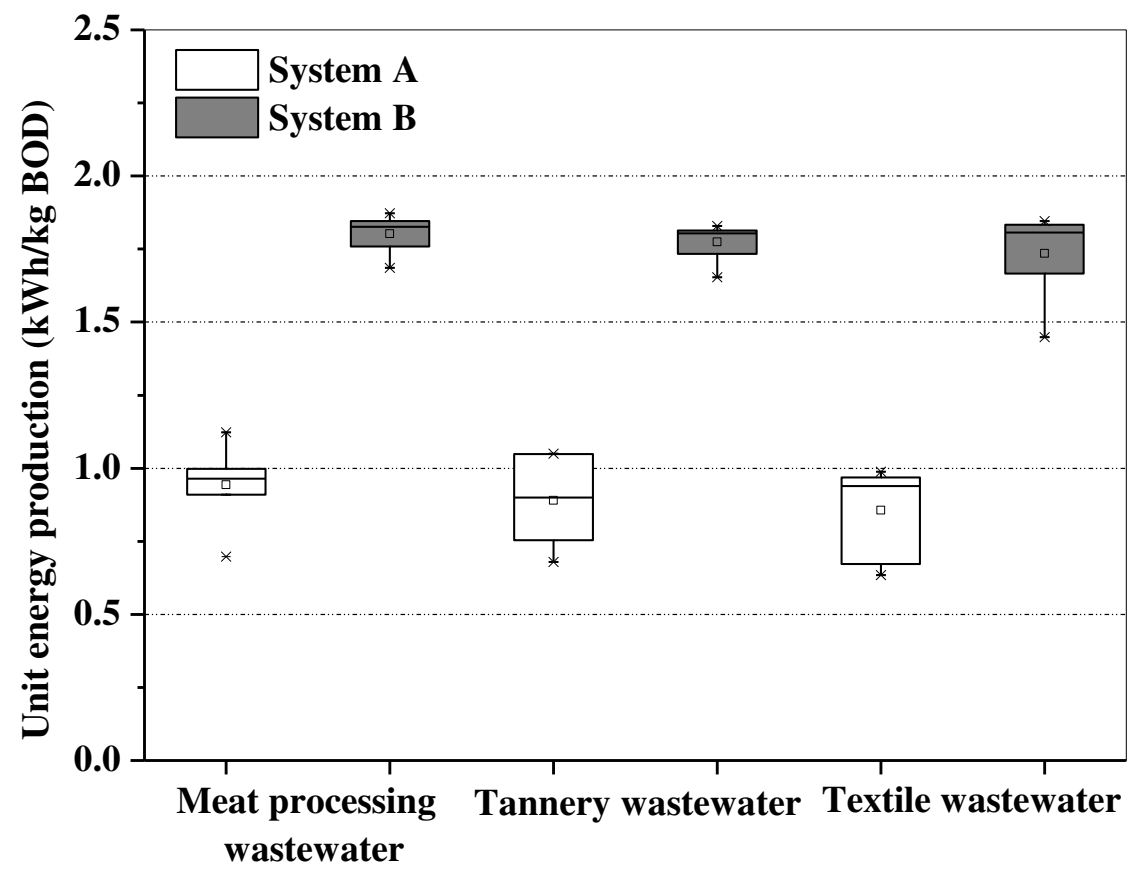

535

Figure 15 Unit electricity production

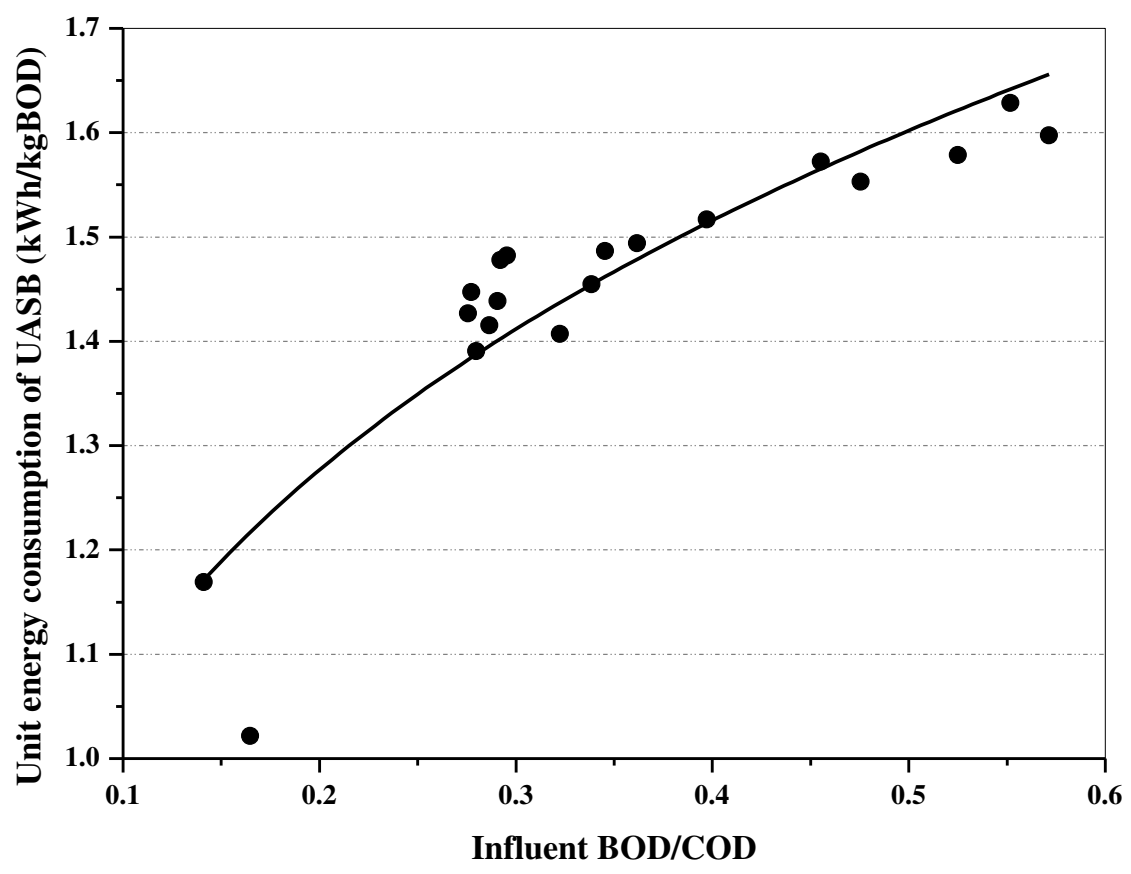


$540 \quad$ Figure 17 shows the influence of different industrial wastewater on energy recovery

541 of two treatment systems. System A for treating industrial wastewater could not 542 produce enough electricity to satisfy the energy demand for oxygen production due to 543 the energy ratio of less than 1 . Since UASB effectively converts $\mathrm{COD}$ to $\mathrm{CH}_{4}$ and $\mathrm{PN} / \mathrm{A}$ 544 decreases energy consumption for removing $\mathrm{N}$, innovative technologies could help 545 industrial wastewater treatment achieve electrical self-sufficiency, as shown in Figure 546 17. Meat processing wastewater has higher BOD concentration and BOD/COD ratio. 547 However, $\mathrm{N}$ concentration of meat processing wastewater is higher than other industrial 548 wastewaters. Energy consumption and energy production are influenced by BOD and $549 \mathrm{~N}$ concentration, respectively. In system $\mathrm{B}$, energy recovery ratio is positive related to $550 \mathrm{BOD} / \mathrm{N}$ ratio, as shown in Figure 18. High BOD and $\mathrm{N}$ concentration of meat 551 processing wastewater leads to relatively lower BOD/COD ratio and energy recovery 552 ratio. Although textile wastewater has lower BOD concentration, the value of the 553 energy ratio for textile treatment system B could be as high as 17.7 because of lower $\mathrm{N}$ 554 concentration and higher $\mathrm{BOD} / \mathrm{N}$ ratio. The minimal energy ratio is 7.0 which is seven 555 times higher than 1 . The mean energy ratio is 14.3 . Therefore, $\mathrm{BOD} / \mathrm{N}$ ratio 556 significantly affects energy recovery of treatment system with innovative technologies. 


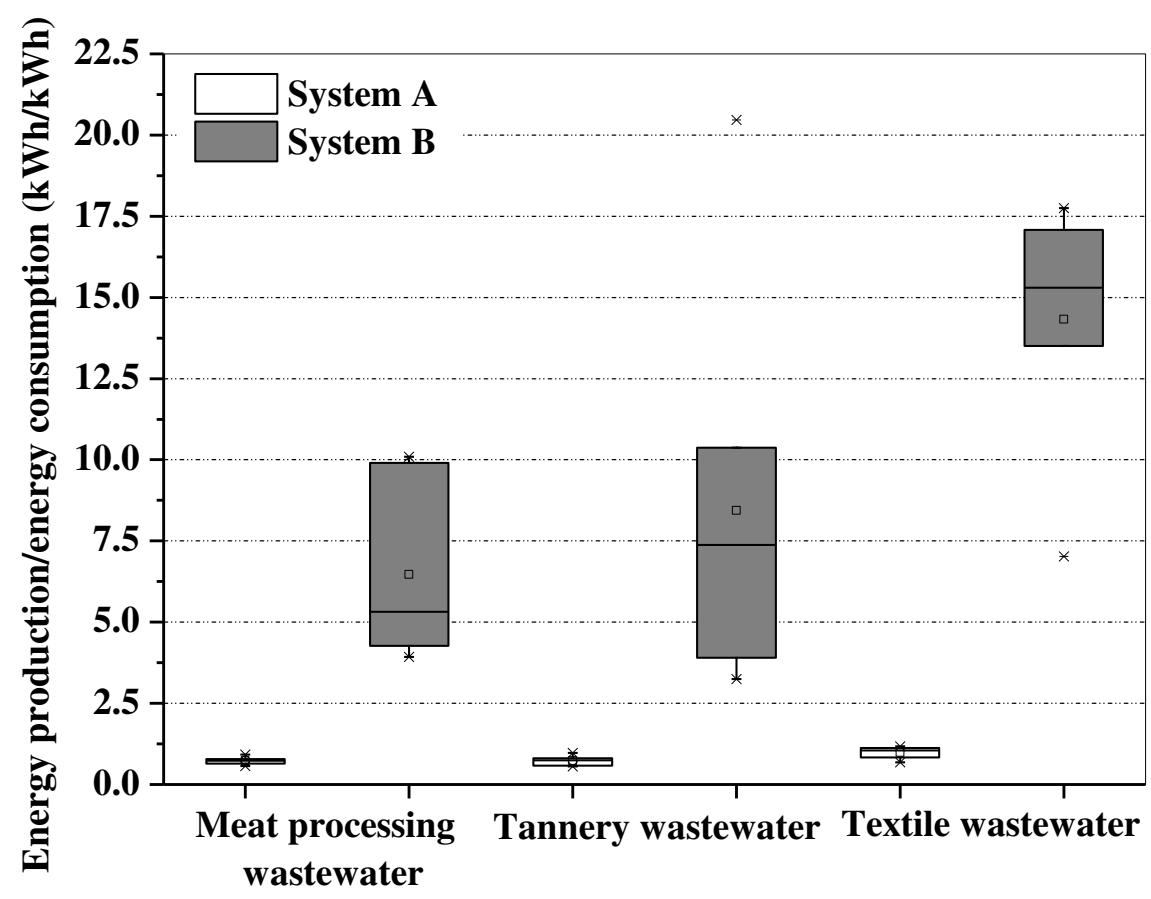

Figure 17 Energy recovery ratio of system A and B

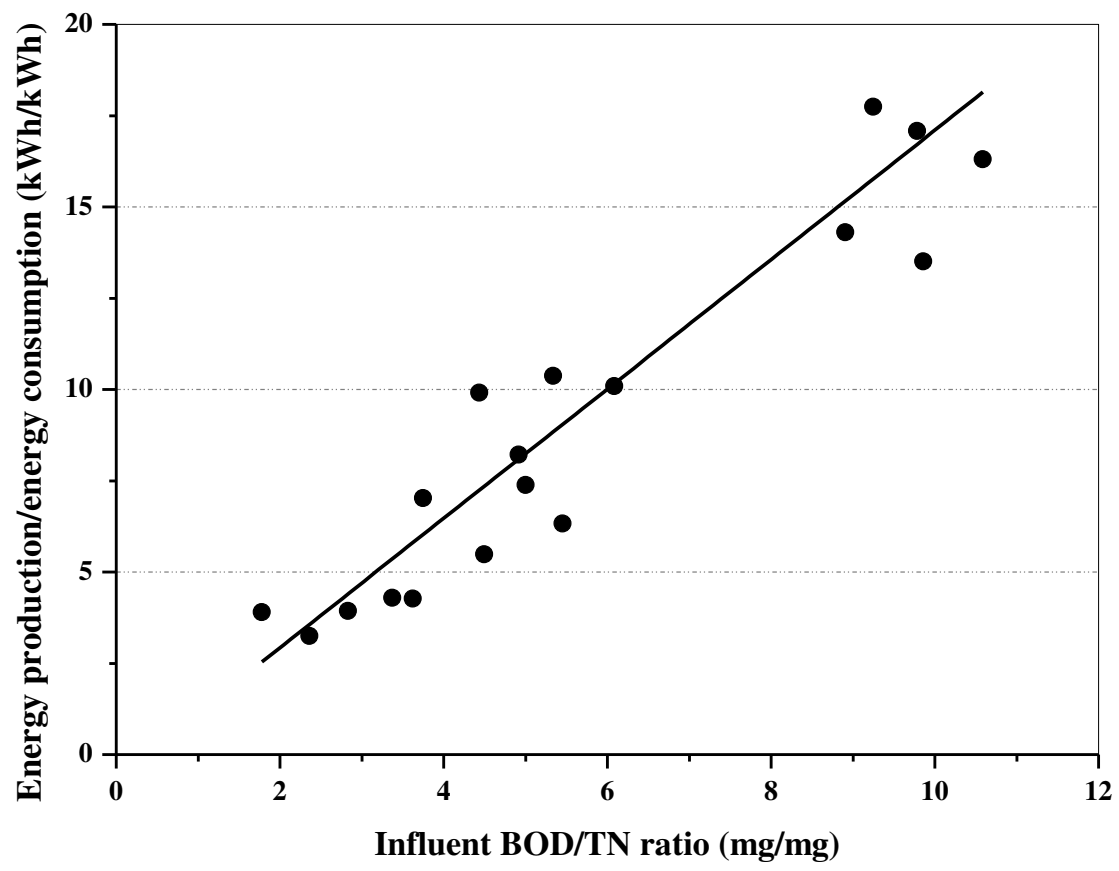

$560 \quad$ Figure 18 Energy recovery ratio as a function of daily influent BOD/ TN ratio in 


\subsection{Environmental indicators}

The contributors of system A and B to global warming and eutrophication potential

564 are shown in Figure 19 and 20. Since the global warming potential is higher than 0, 565 activated sludge process with nitrification-denitrification for treating industrial 566 wastewater could not be considered as the sustainable design. Energy significantly 567 affects global warming potential of treatment systems. System B could produce enough 568 electricity to satisfy the aeration demand. The energy production could offset the 569 overall global warming potential in system B, as shown in Figure 19. Therefore, 570 achieving energy positive by innovative technologies could effectively reduce impacts 571 of industrial wastewater treatment on the global warming. Due to high energy recovery 572 ratio, the eutrophication potential of treatment system B is lower than that of system A, 573 as shown in Figure 20. Since the eutrophication potential is affected by effluent 574 pollutant mass, meat processing wastewater treatment has higher eutrophication 575 potential than textile wastewater treatment. Many researchers did not consider the 576 physical-chemical treatment when designing wastewater treatment system [76, 77, 577 116]. The physical-chemical treatment is not necessary because non-biodegradable 578 COD of municipal wastewater is low enough to meet discharge requirements. 579 However, meat processing wastewater has high concentration of COD and non580 biodegradable COD. This results in a high eutrophication potential of food processing 581 wastewater treatment. UASB and activated sludge process could not remove non582 biodegradable matter. Therefore, the physical-chemical treatment is required to be 583 applied in the future food processing wastewater treatment design for removing non584 biodegradable COD. 


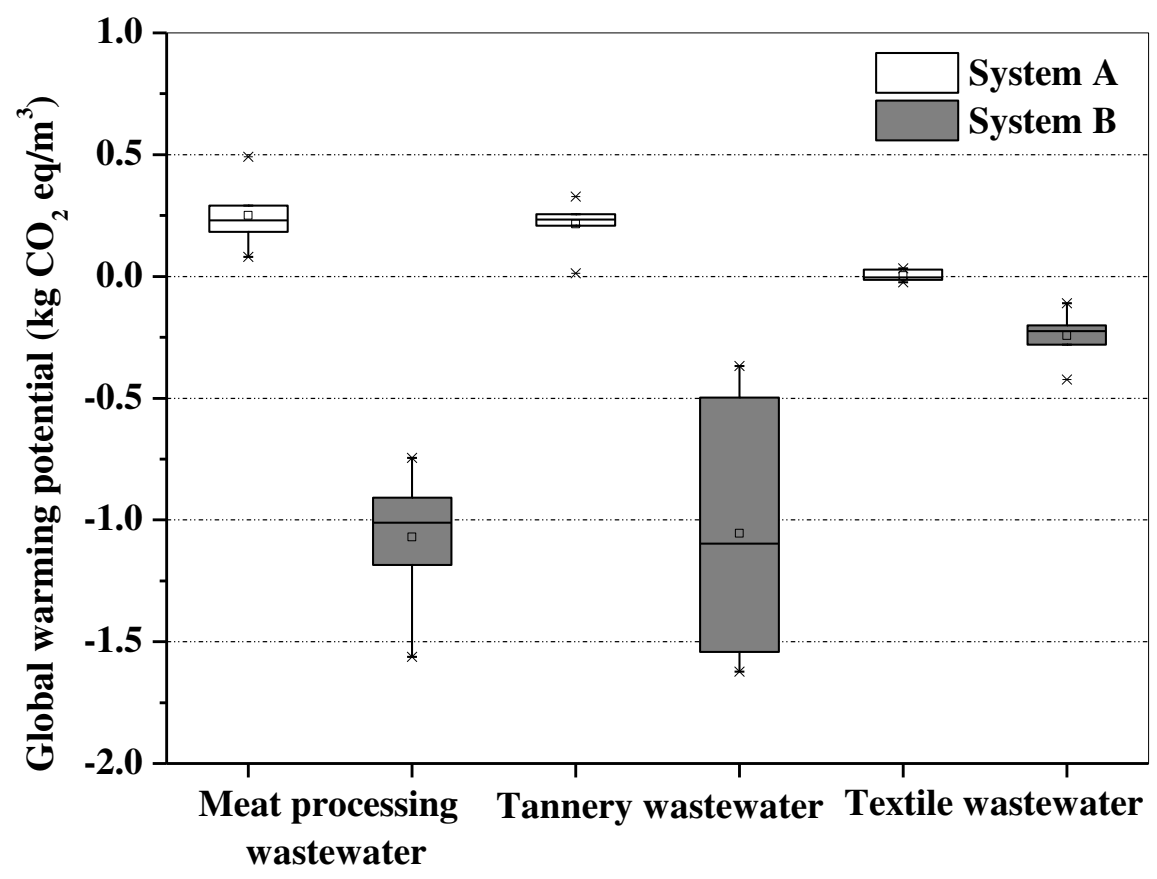

585

586 Figure 19 Global warming potential of 3 industrial wastewater in two treatment

systems

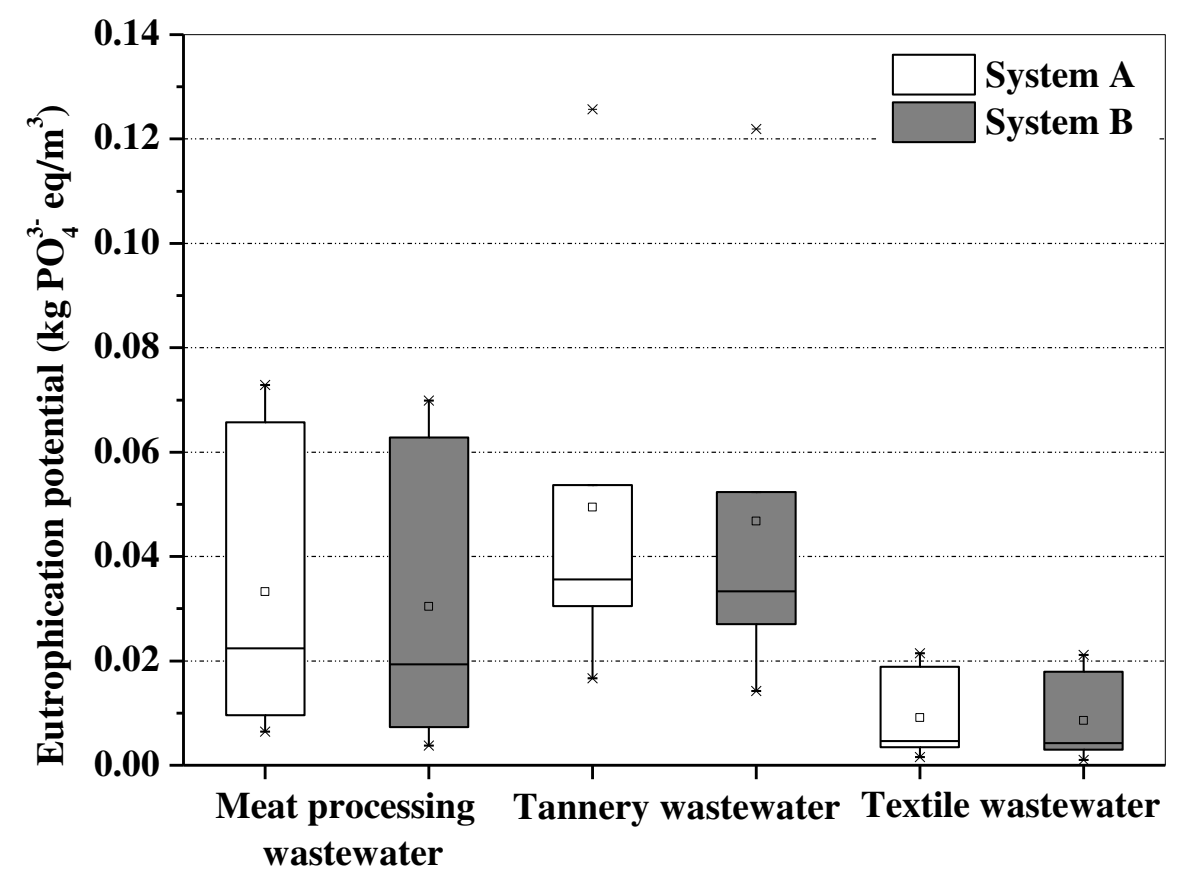

Figure 20 Eutrophication potential of three industrial wastewaters 
in two treatment systems

\subsection{Cost analysis}

592 Unit cost analysis of treatment systems based on different industrial wastewater 593 quality compares the cost of these systems. Since COD removal by primary treatment 594 and secondary treatment are positively related to TSS/COD ratio and BOD/COD ratio, 595 unit cost metric $\left(\$ / \mathrm{kg} \mathrm{COD}_{\text {removed }}\right)$ is used as the indicator in this study. Figure 21 compares the unit cost $\left(\$ / \mathrm{kg} C \mathrm{CD}_{\text {removed }}\right)$ of two systems for treating different industrial wastewater. Although application of UASB and PN/A in system B increase the corresponding cost, UASB and PN/A reduces influent BOD and N loading and required

599 size of activated sludge process with nitrification-denitrification. Figure 21

600 demonstrates that the unit cost of system B is lower than that of system A. Since 601 economic income due to energy recovery and cost saving is higher than the increased 602 cost of innovative technologies, innovative biological technologies could replace the 603 old process. In system B, the average unit cost for meat processing wastewater, tannery 604 wastewater, and textile wastewater are $0.54,0.57$, and $1.12 \$ / \mathrm{kg}$ COD removal, 605 respectively. The unit cost for meat processing wastewater is lower than that for the 606 other wastewaters. Compared with other wastewater, meat processing wastewater has 607 a higher biodegradability and concentration of BOD, which could produce a large 608 amount of $\mathrm{CH}_{4}$ for energy recovery to reduce the unit cost of a treatment system. On 609 the other hand, COD removal strongly affects unit costs of the main unit process as 610 shown in Figures 22. The unit cost of UASB systems decrease with increasing COD 611 removal. The unit capital cost $\left(\$ /\right.$ reactor volume $\left.\mathrm{m}^{3}\right)$ of UASB is much higher than that 612 of activated sludge tank for small-sized WWTPs, as shown in Table 9. The total cost 613 of treatment system is significantly by the cost of UASB. Although textile wastewater 614 has the highest energy recovery ratio, the COD concentration of textile wastewater is 
615 lower than that of other wastewaters. This leads to higher unit costs of the UASB. The

616 meat processing wastewater system consumes more oxygen for removing N in PN/A.

617 However, this process increases the $\mathrm{CH}_{4}$ production of $\mathrm{AD}$ through increasing biomass.

618 Higher biodegradability and pollutant concentration reduce the unit cost of the meat 619 processing wastewater treatment system. Therefore, it is more economical to treat meat 620 processing wastewater with innovative technologies.

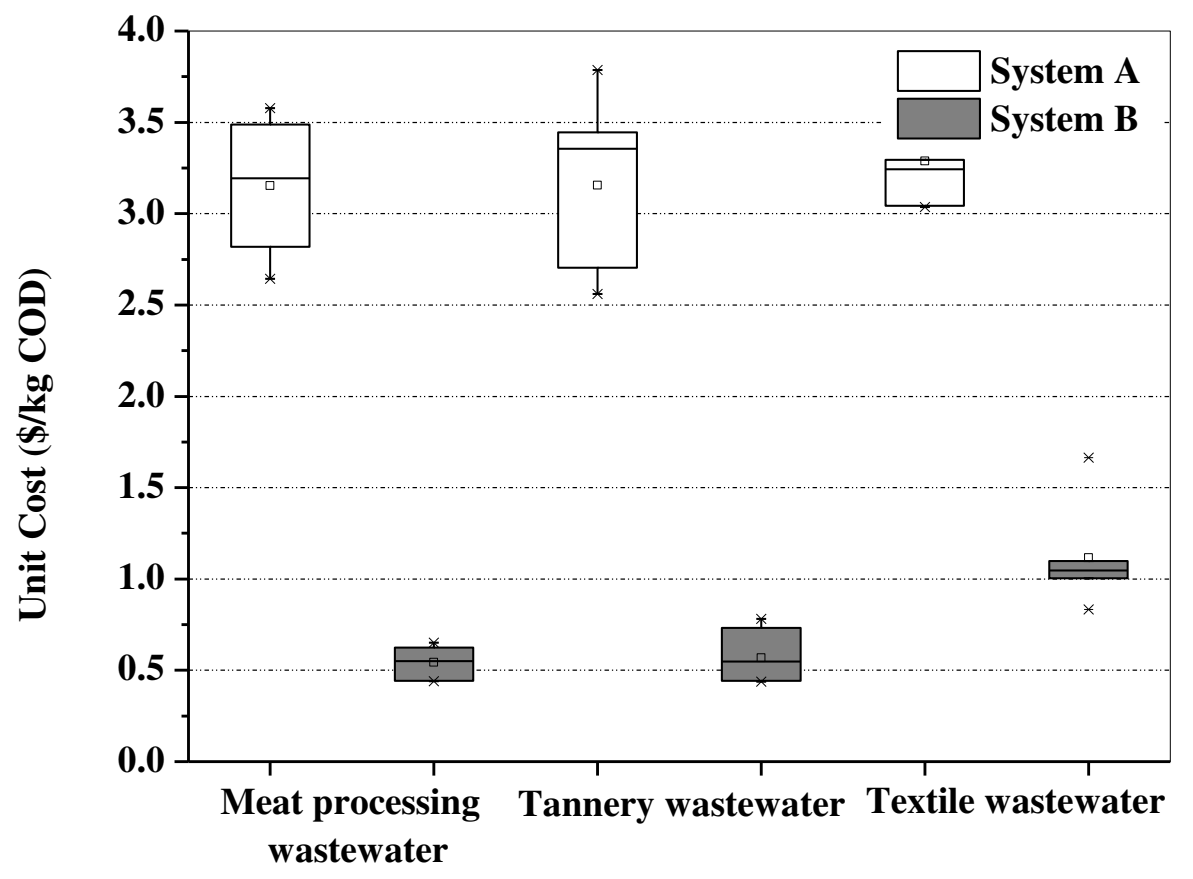

621

Figure 21 Unit cost of different industrial wastewater treatment 


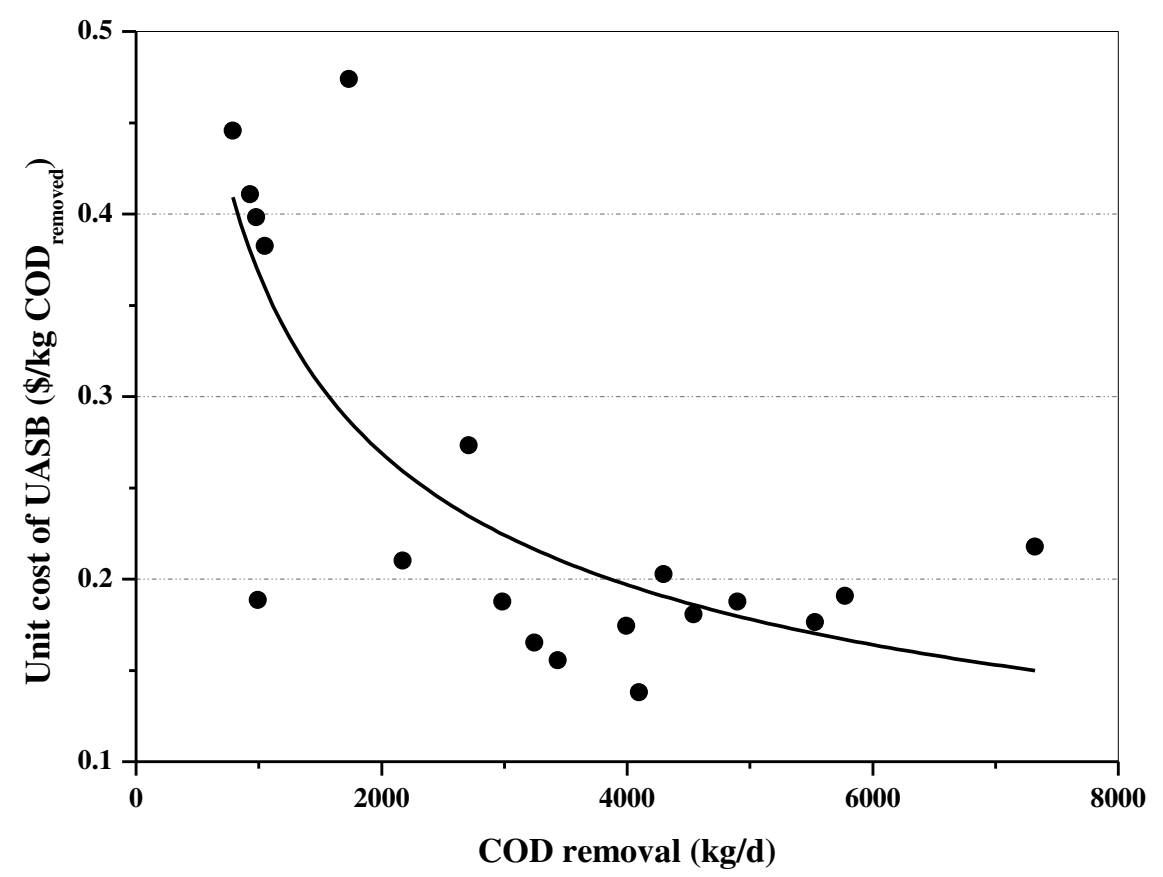

623

631 wastewater. Results showed that micro-sieving could remove $35.36 \%, 39.08 \%$, and $63232.50 \%$ of COD for tannery, meat processing, and textile wastewater, respectively. Due 633 to the relatively high TSS/COD ratio, primary treatment could achieve high COD 634 removal efficiency of textile wastewater with low TSS concentration as compared to 

more $\mathrm{COD}$ to $\mathrm{CH}_{4}$ in meat process wastewater with high BOD concentration because

638 of the high BOD/COD ratio. Pearson correlation analysis shows that the TSS/COD 639 ratio and BOD/COD ratio are the key parameters in determining COD removal and 640 methane conversion rate of primary treatment and secondary treatment. These 641 regression equations could be used to predict COD removal by the primary and 642 biological processes as follows:

$$
\text { COD removal }(\%)=75.69(\mathrm{BOD} / \mathrm{COD} \text { ratio })+57.53(\mathrm{TSS} / \mathrm{COD}
$$

$$
\begin{array}{ll}
\text { ratio) }+23.15 & \mathrm{R}^{2}=0.929
\end{array}
$$

643 For meat processing wastewater, tannery wastewater, and textile wastewater, the mean 644 unit energy consumptions were $1.49,1.37$, and $1.39 \mathrm{kWh} / \mathrm{kg} \mathrm{N}$ removal, which are close 645 to actual unit energy consumption of PN/A process. Mean unit energy production for 646 three types of wastewater in innovative system are $1.80,1.77$, and $1.73 \mathrm{kWh} / \mathrm{kg} \mathrm{BOD}$ 647 removal, respectively. The energy positive system for treating meat processing 648 wastewater could produce more energy for removing the same amount of BOD than 649 other than other industrial wastewater treatment systems. The average unit cost for 650 meat processing wastewater, tannery wastewater, and textile wastewater are $0.54,0.57$, 651 and $1.12 \$ / \mathrm{kg}$ COD removal, respectively. Textile wastewater treatment has the highest 652 energy recovery ratio. However, the low COD concentration of textile wastewater 653 leads to high unit cost of system. Meat processing wastewater has higher COD 654 concentration and biodegradability than other wastewaters, which reduce unit cost of 655 UASB and increases electricity production through increasing COD loading rate to 656 UASB and AD. A low unit cost of UASB and a high $\mathrm{CH}_{4}$ production rate improves the 657 unit cost of meat processing wastewater treatment systems. Therefore, it is more 
658 economical and easier to treat meat processing wastewater with micro sieving, UASB,

659 and PN/A technologies than other industrial wastewaters. Due to high energy recovery,

660 innovative technologies could effectively reduce effect of industrial wastewater

661 treatment on the global warming. However, meat processing wastewater treatment with

662 innovative technologies shows high eutrophication potential because of its high non-

663 biodegradable COD concentration. UASB with anammox treatment for treating meat

664 processing wastewater could not be considered as the sustainable option when the

665 eutrophication criterion and discharge requirement are prioritized. Therefore, physical-

666 chemical treatment may be required in the future food processing wastewater treatment

667 design to remove non-biodegradable COD. The economic advantages and limitations

668 of innovative technologies in treating industrial wastewater have been quantified by

669 using unit energy and cost per kg pollutant removed which provide valuable references

670 for future sustainable design of industrial wastewater treatment systems.

$671 \quad$ 5. Additional information

672 Availability of data and materials

673 The data supporting the conclusions of this study are available within the article.

674 Competing interests

675 The authors claim no conflict of interests.

676 Funding

677 The Department of Civil and Environmental Engineering at Florida International

678 University support Jinze Li with Teaching Assistantship while Jinze Li could pursue 679 this research.

680 Authors' contributions

681 All authors contributed to the study conception and design. Material preparation, 682 data collection and analysis were performed by Jinze Li. The first draft of the 
683 manuscript was written by Jinze Li and all authors commented on previous versions of 684 the manuscript. All authors read and approved the final manuscript.

685 - Conceptualization: Walter Z. Tang and Jinze Li; Methodology: Jinze Li and 686 Walter Z. Tang; Formal analysis and investigation: Jinze Li; Writing - original draft 687 preparation: Jinze Li; Writing - review and editing: Walter Z. Tang; Funding 688 acquisition: Jinze Li; Resources: Department of Civil and Environmental Engineering, 689 Florida International University, Miami, Florida 33199; Supervision: Dr. Atorod 690 Azizinamini.

\section{Acknowledgments}

692 The authors acknowledge the financial support to Jinze Li by the Department of 693 Civil and Environmental Engineering, Florida International University, Miami, Florida 69433199.

\section{Reference}

696 [1] Burian, S.J., Nix, S.J., Pitt, R.E.,Durrans, S.R., 2000. Urban wastewater management in the United States: Past, present, and future. Journal of Urban 698 Technology. 7, 33-62. https://doi.org/10.1080/713684134

699 [2] Tchobanoglus, G., Burton, F.,Stensel, H.D., 2003. Wastewater engineering: 700 Treatment and reuse. American Water Works Association. Journal. 95, 201.

701 [3] Paraskeva, P.,Diamadopoulos, E., 2006. Technologies for olive mill wastewater 702 (OMW) treatment: a review. Journal of Chemical Technology \& Biotechnology: 703 International Research in Process, Environmental \& Clean Technology. 81, 1475-1485.

\section{4 https://doi.org/10.1002/jctb.1553}

705 [4] Boopathy, R., Larsen, V.F.,Senior, E., 1988. Performance of anaerobic baffled 706 reactor $(\mathrm{ABR})$ in treating distillery waste water from a scotch whisky factory. Biomass. 
708 [5] Gerbens-Leenes, P.W., Mekonnen, M.M.,Hoekstra, A.Y., 2013. The water footprint

709 of poultry, pork and beef: A comparative study in different countries and production 710 systems. Water $\quad$ Resources and $\quad$ Industry.

711 https://doi.org/10.1016/j.wri.2013.03.001

712 [6] Mekonnen, M.M.,Hoekstra, A.Y., 2012. A global assessment of the water footprint 713 of farm animal products. Ecosystems. 15, 401-415. https://doi.org/10.1007/s10021$714 \quad 011-9517-8$

715 [7] Bustillo-Lecompte, C.F.,Mehrvar, M., 2015. Slaughterhouse wastewater 716 characteristics, treatment, and management in the meat processing industry: A review 717 on trends and advances. Journal of Environmental Management. 161, 287-302. 718 https://doi.org/10.1016/j.jenvman.2015.07.008

719 [8] Cao, W.,Mehrvar, M., 2011. Slaughterhouse wastewater treatment by combined 720 anaerobic baffled reactor and UV/H2O2 processes. Chemical Engineering Research 721 and Design. 89, 1136-1143. https://doi.org/10.1016/j.cherd.2010.12.001

722 [9] Khamtib, S.,Reungsang, A., 2014. Co-digestion of oil palm trunk hydrolysate with 723 slaughterhouse wastewater for thermophilic bio-hydrogen production by 724 Thermoanaerobacterium thermosaccharolyticm KKU19. International Journal of 725 Hydrogen Energy. 39, 6872-6880. https://doi.org/10.1016/j.ijhydene.2014.02.073

726 [10] Bustillo-Lecompte, C., Mehrvar, M.,Quiñones-Bolaños, E., 2016. Slaughterhouse 727 wastewater characterization and treatment: an economic and public health necessity of 728 the meat processing industry in Ontario, Canada. Journal of Geoscience and 729 Environment Protection. 4, 175-186. https://doi.org/10.4236/gep.2016.44021

730 [11] EPA, 2004. Effluent limitations guidelines and new source performance standards 731 for the meat and poultry products, point source category. Environmental Protection 732 Agency (EPA): Federal Register. 69. 
734 guidelines-and-new-source-performance-standards-for-the-meat-and-poultry

735 [12] Kundu, P., Debsarkar, A.,Mukherjee, S., 2013. Treatment of slaughter house 736 wastewater in a sequencing batch reactor: performance evaluation and biodegradation 737 kinetics. BioMed research international. 2013. https://doi.org/10.1155/2013/134872

738 [13] Durai, G.,Rajasimman, M., 2011. Biological Treatment of Tannery Wastewater739 A Review. Journal of Environmental science and Technology. 4, 1-17. 740 https://doi.org/10.3923/jest.2011.1.17

741 [14] Famielec, S.,Wieczorek-Ciurowa, K., 2011. Waste from leather industry. Threats 742 to the environment. Czasopismo Techniczne. Chemia. 108, 43-48. 743 https://suw.biblos.pk.edu.pl/resources/i4/i5/i4/i6/r4546/FamielecS WasteLeather.pdf

744 [15] United Nations Industrial Development Organization, 1991. Tanneries and the 745 Environment: A Technical Guide to Reducing the Environmental Impact of Tannery 746 Operations. United Nations Environment Programme, Industry and Environment 747 Office. https://books.google.com/books?id=FHDbAAAAMAAJ

748 [16] European Commission, 2001. Integrated Pollution Prevention and Control (IPPC) 749 Reference Document on Best Available Techniques for the Tanning of Hides and Skins 750 May 2001. https://p2infohouse.org/ref/21/20575.pdf

751 [17] Lofrano, G., Meriç, S., Zengin, G.E.,Orhon, D., 2013. Chemical and biological 752 treatment technologies for leather tannery chemicals and wastewaters: a review. 753 Science of the Total Environment. 461, 265-281. 754 https://doi.org/10.1016/j.scitotenv.2013.05.004

755 [18] Mwinyihija, M., 2010. Ecotoxicological Diagnosis in the Tanning Industry. 756 Springer New York. https://books.google.com/books?id=a53Z9sUKAdUC 
757 [19] Abdulla, H.M., Kamal, E.M., Mohamed, A.H.,El-Bassuony, A.D. Year.

758 Chromium removal from tannery wastewater using chemical and biological techniques

759 aiming zero discharge of pollution. in Proceeding Of Fifth Scientific Environmental 760 Conference. 2010.

761 [20] de Aquim, P.M., Hansen, É.,Gutterres, M., 2019. Water reuse: An alternative to 762 minimize the environmental impact on the leather industry. Journal of Environmental 763 Management. 230, 456-463. https://doi.org/10.1016/j.jenvman.2018.09.077

764 [21] Elabbas, S., Ouazzani, N., Mandi, L., Berrekhis, F., Perdicakis, M., Pontvianne, 765 S., Pons, M.-N., Lapicque, F.,Leclerc, J.-P., 2016. Treatment of highly concentrated 766 tannery wastewater using electrocoagulation: influence of the quality of aluminium 767 used for the electrode. Journal of Hazardous Materials. 319, 69-77. 768 https://doi.org/10.1016/j.jhazmat.2015.12.067

769 [22] Hassen, A.S.,Woldeamanuale, T.B., 2017. Evaluation and Characterization of 770 Tannery Wastewater in each process at batu and modjo tannery, Ethiopia. Int J Rural 771 Dev Environ Health Res. 1, 17-26.

772 [23] Islam, B.I., Musa, A.E., Ibrahim, E.H., Sharafa, S.A.A.,Elfaki, B.M., 2014. 773 Evaluation and characterization of tannery wastewater. Journal of Forest Products \& 774 Industries. 3, 141-150.

775 [24] Nandy, T., Kaul, S.N., Shastry, S., Manivel, U.,Deshpande, C.V., 1999. 776 Wastewater Management in Cluster of Tanneries in Tamil Nadu through 777 Implementation of Common Effluent Treatment Plants+. 778 http://nopr.niscair.res.in/bitstream/123456789/17844/1/JSIR\%2058\%287\%29\%20475 $779 \quad \underline{-516 . p d f}$

780 [25] Robinson, T., McMullan, G., Marchant, R.,Nigam, P., 2001. Remediation of dyes 781 in textile effluent: a critical review on current treatment technologies with a proposed 
alternative. Bioresource Technology. 77, 247-255. https://doi.org/10.1016/S0960$\underline{8524(00) 00080-8}$

[26] Villegas-Navarro, A., Ramírez-M, Y., Salvador-SB, M.S.,Gallardo, J.M., 2001.

Determination of wastewater LC50 of the different process stages of the textile industry. Ecotoxicology and Environmental Safety. 48, 56-61. https://doi.org/10.1006/eesa.2000.1986

[27] Wang, C., Yediler, A., Lienert, D., Wang, Z.,Kettrup, A., 2002. Toxicity evaluation of reactive dyestuffs, auxiliaries and selected effluents in textile finishing industry to luminescent bacteria Vibrio fischeri. Chemosphere. 46, 339-344. https://doi.org/10.1016/S0045-6535(01)00086-8

[28] EPA, 1997. EPA Office of Compliance Sector Notebook Project : profile of the textile industry. https://nepis.epa.gov/Exe/ZyPDF.cgi?Dockey=50000HE9.PDF

[29] Volmajer Valh, J., Majcen Le Marechal, A., Vajnhandl, S., Jeric, T.,Šimon, E., 2011. Water in the textile industry. Treatise on Water Science; Wilderer, P., Ed.; Elsevier: Oxford, UK. 685-706.

[30] Vijayaraghavan, G.,Shanthakumar, S., 2015. Removal of sulphur black dye from its aqueous solution using alginate from Sargassum sp.(Brown algae) as a coagulant. Environmental Progress \& Sustainable Energy. 34, 1427-1434. https://doi.org/10.1002/ep.12144

[31] Noreen, M., Shahid, M., Iqbal, M.,Nisar, J., 2017. Measurement of cytotoxicity and heavy metal load in drains water receiving textile effluents and drinking water in vicinity of drains. Measurement. 109, 88-99.

\section{https://doi.org/10.1016/j.measurement.2017.05.030}

[32] Ganesh, R., Boardman, G.D.,Michelsen, D., 1994. Fate of azo dyes in sludges. Water Research. 28, 1367-1376. https://doi.org/10.1016/0043-1354(94)90303-4 

textile reactive azo dyes after hydrolysis and decolourisation. Journal of Biotechnology. 101, 49-56. https://doi.org/10.1016/S0168-1656(02)00302-4

810 [34] Meriç, S., Kaptan, D.,Ölmez, T., 2004. Color and COD removal from wastewater 811 containing Reactive Black 5 using Fenton's oxidation process. Chemosphere. 54, 435812 441. https://doi.org/10.1016/j.chemosphere.2003.08.010

813 [35] Ullah, T., Sultana, T., Khan, L., Feroz, K., Ahmad, Q.A.,Hussain, S., 2017. 814 Histopathological alteration in Gill, Kidney and Liver of Cirrhinus mrigala, Catla catla, 815 Hypophthalmichthys molitrix and Labeo rohita due to sub-lethal exposure of textile 816 industries effluents in Faisalabad, Pakistan. Pakistan. J. Entomol. Zool. Stud. 5, e62.

817 [36] Najam-us-Sahar, Hussain, A., Mustafa, A., Waqas, R., Ashraf, I.,Zaman Akhtar, 818 M.F.U., 2017. Effect of textile wastewater on growth and yield of wheat (Triticum 819 aestivum $\quad$ L.). Soil \& $\quad$ Environment. 36, 28 -34. 820 https://www.researchgate.net/publication/316169367_Effect_of_textile_wastewater_o 821 n_growth_and_yield_of_wheat_Triticum_aestivum_L

822 [37] Daud, M.K., Nafees, M., Ali, S., Rizwan, M., Bajwa, R.A., Shakoor, M.B., Arshad, 823 M.U., Chatha, S.A.S., Deeba, F., Murad, W., Malook, I.,Zhu, S.J., 2017. Drinking water 824 quality status and contamination in Pakistan. BioMed research international. 2017. 825 https://doi.org/10.1155/2017/7908183

826 [38] Al-Mutairi, N.Z., Hamoda, M.F.,Al-Ghusain, I.A., 2007. Slaughterhouse 827 wastewater treatment using date seeds as adsorbent. Journal of Environment Science 828 and Health. 55, 678-710.

829 [39] Boopathy, R., Bonvillain, C., Fontenot, Q.,Kilgen, M., 2007. Biological treatment 830 of low-salinity shrimp aquaculture wastewater using sequencing batch reactor. 
831 International Biodeterioration \& Biodegradation. 59, 16-19.

\section{2 https://doi.org/10.1016/j.ibiod.2006.05.003}

833 [40] Kim, H.S., Choung, Y.K., Ahn, S.,Oh, H.S., 2008. Enhancing nitrogen removal of

834 piggery wastewater by membrane bioreactor combined with nitrification reactor.

835 Desalination. 223, 194-204. https://doi.org/10.1016/j.desal.2006.12.021

836 [41] Al-Mutairi, N.Z., Al-Sharifi, F.A.,Al-Shammari, S.B., 2008. Evaluation study of 837 a slaughterhouse wastewater treatment plant including contact-assisted activated sludge 838 and DAF. Desalination. 225, 167-175. https://doi.org/10.1016/j.desal.2007.04.094

839 [42] Roy, D., Hassan, K.,Boopathy, R., 2010. Effect of carbon to nitrogen (C: N) ratio 840 on nitrogen removal from shrimp production waste water using sequencing batch 841 reactor. Journal of industrial microbiology \& biotechnology. 37, 1105-1110. 842 https://doi.org/10.1007/s10295-010-0869-4

843 [43] Rajagopal, R., Rousseau, P., Bernet, N.,Béline, F., 2011. Combined anaerobic and 844 activated sludge anoxic/oxic treatment for piggery wastewater. Bioresource 845 Technology. 102, 2185-2192. https://doi.org/10.1016/j.biortech.2010.09.112

846 [44] Palatsi, J., Viñas, M., Guivernau, M., Fernandez, B.,Flotats, X., 2011. Anaerobic 847 digestion of slaughterhouse waste: main process limitations and microbial community 848 interactions. $\quad$ Bioresource $\quad$ Technology. $\quad 102, \quad 2219-2227$. 849 https://doi.org/10.1016/j.biortech.2010.09.121

850 [45] Kern, C.,Boopathy, R., 2012. Use of sequencing batch reactor in the treatment of 851 shrimp aquaculture wastewater. Journal of Water Sustainability. 2, 221-232. 852 http://citeseerx.ist.psu.edu/viewdoc/download?doi=10.1.1.453.7245\&rep=rep1\&type= 853 pdf

854 [46] Wang, F., Liu, Y., Wang, J., Zhang, Y.,Yang, H., 2012. Influence of growth 855 manner on nitrifying bacterial communities and nitrification kinetics in three lab-scale 
856 bioreactors. Journal of industrial microbiology \& biotechnology. 39, 595-604.

857 https://doi.org/10.1007/s10295-011-1065-X

858 [47] Jawahar, A.J., Chinnadurai, M., Ponselvan, J.K.,Annadurai, G., 1998. Pollution

859 from tanneries and options for treatment of effluent. Indian Journal of Environmental

860 Protection. 18, 672-678.

861 [48] Eckenfelder, W.W., 2000. Industrial Water Pollution Control. McGraw-Hill. 862 https://books.google.com/books?id=hRtSAAAAMAAJ

863 [49] Tare, V., Gupta, S.,Bose, P., 2003. Case studies on biological treatment of tannery

864 effluents in India. Journal of the air \& waste management association. 53, 976-982.

865 https://doi.org/10.1080/10473289.2003.10466250

866 [50] Ahn, D.H., Chung, Y.C., Yoo, Y.J., Pak, D.W.,Chang, W.S., 1996. Improved 867 treatment of tannery wastewater using Zoogloea ramigera and its extracellular polymer 868 in an activated sludge process. Biotechnology letters. 18, 917-922. 869 https://doi.org/10.1007/BF00154621

870 [51] Vijayaraghavan, K.,Murthy, D.V.S., 1997. Effect of toxic substances in anaerobic 871 treatment of tannery wastewaters. Bioprocess Engineering. 16, 151-155. 872 https://doi.org/10.1007/s004490050302

873 [52] Wiemann, M., Schenk, H.,Hegemann, W., 1998. Anaerobic treatment of tannery 874 wastewater with simultaneous sulphide elimination. Water Research. 32, 774-780. 875 https://doi.org/10.1016/S0043-1354(97)00309-6

876 [53] Di Iaconi, C., Lopez, A., Ramadori, R.,Passino, R., 2003. Tannery wastewater 877 treatment by sequencing batch biofilm reactor. Environmental Science \& Technology. 878 37, 3199-3205. https://doi.org/10.1021/es030002u 
879 [54] Farabegoli, G., Carucci, A., Majone, M.,Rolle, E., 2004. Biological treatment of 880 tannery wastewater in the presence of chromium. Journal of Environmental 881 Management. 71, 345-349. https://doi.org/10.1016/j.jenvman.2004.03.011

882 [55] Schrank, S.G., Jose, H.J., Moreira, R.F.P.M.,Schröder, H.F., 2004. Elucidation of 883 the behavior of tannery wastewater under advanced oxidation conditions. 884 Chemosphere. 56, 411-423. https://doi.org/10.1016/j.chemosphere.2004.04.012

885 [56] Sekaran, G., Chitra, K., Mariappan, M.,Raghavan, K.V., 1996. Removal of 886 sulphide in anaerobically treated tannery wastewater by wet air oxidation. Journal of 887 Environmental Science \& Health Part A. 31, 579-598. 888 https://doi.org/10.1080/10934529609376375

889 [57] Dogruel, S., Genceli, E.A., Babuna, F.G.,Orhon, D., 2004. Ozonation of 890 nonbiodegradable organics in tannery wastewater. Journal of Environmental Science 891 and Health, Part A. 39, 1705-1715. https://doi.org/10.1081/ESE-120037871

892 [58] Song, Z., Williams, C.J.,Edyvean, R.G.J., 2004. Treatment of tannery wastewater 893 by chemical coagulation. Desalination. 164, 249-259. https://doi.org/10.1016/S0011894 9164(04)00193-6

895 [59] Churchley, J.H., 1994. REMOVAL OF DYEW ASTE COLOUR FROM SEW 896 AGE EFFLUENT-THE USE OF A FULL SCALE OZONE PLANT. Water Science 897 and $\quad$ Technology. $\quad 30, \quad 275$. 898 https://search.proquest.com/openview/7db123fa0f6d45f15604e6f854e6d5b6/1?pq-

899 origsite $=$ gscholar \&cbl $=2044520$

900 [60] Stern, S.R., Szpyrkowicz, L.,Rodighiero, I., 2003. Anaerobic treatment of textile 901 dyeing wastewater. Water Science and Technology. 47, 55-59. 902 https://doi.org/10.2166/wst.2003.0537 
903 [61] Chu, W., 2001. Dye removal from textile dye wastewater using recycled alum 904 sludge. Water Research. 35, 3147-3152. https://doi.org/10.1016/S0043$905 \quad \underline{1354(01) 00015-X}$

906 [62] Dąbrowski, W., Żyłka, R.,Rynkiewicz, M., 2016. Evaluation of energy 907 consumption in agro-industrial wastewater treatment plant. Journal of Ecological 908 Engineering. 17, 73--78. https://doi.org/10.12911/22998993/63306

909 [63] Yang, X., López-Grimau, V., Vilaseca, M.,Crespi, M., 2020. Treatment of Textile 910 Wastewater by CAS, MBR, and MBBR: A Comparative Study from Technical, 911 Economic, and Environmental Perspectives. Water. 12, 1306.

912 https://doi.org/10.3390/w12051306

913 [64] Gujer, W.,Zehnder, A.J.B., 1983. Conversion Processes in Anaerobic Digestion.

914 Water Science and Technology. 15, 127-167. https://doi.org/10.2166/wst.1983.0164

915 [65] Chong, S., Sen, T.K., Kayaalp, A.,Ang, H.M., 2012. The performance 916 enhancements of upflow anaerobic sludge blanket (UASB) reactors for domestic sludge 917 treatment--a state-of-the-art review. Water Research. 46, 3434-3470. $918 \quad$ https://doi.org/10.1016/j.watres.2012.03.066

919 [66] Abeling, U.,Seyfried, C.F., 1992. Anaerobic-aerobic treatment of high-strength 920 ammonium wastewater-nitrogen removal via nitrite. Water Science and Technology.

$921 \quad 26,1007-1015$. https://doi.org/10.2166/wst.1992.0542

922 [67] van de Graaf, A.A., de Bruijn, P., Robertson, L.A., Jetten, M.S.M.,Kuenen, J.G., 923 1996. Autotrophic growth of anaerobic ammonium-oxidizing micro-organisms in a 924 fluidized bed reactor. Microbiology. 142, 2187-2196. 
926 [68] Strous, M., Kuenen, J.G.,Jetten, M.S.M., 1999. Key Physiology of Anaerobic 927 Ammonium Oxidation. Applied and Environmental Microbiology. 65, 3248-3250.

928 https://doi.org/10.1128/AEM.65.7.3248-3250.1999

929 [69] Giusti, E., Marsili-Libelli, S.,Spagni, A., 2011. Modelling microbial population 930 dynamics in nitritation processes. Environmental Modelling and Software. 26, 938-949.

931 https://doi.org/10.1016/j.envsoft.2011.02.001

932 [70] O'Shaughnessy, M., 2016. Mainstream Deammonification. IWA Publishing. 933 https://doi.org/10.2166/9781780407852

934 [71] Rosenwinkel, K.H.,Cornelius, A., 2005. Deammonification in the Moving-Bed 935 Process for the Treatment of Wastewater with High Ammonia Content. Chemical 936 Engineering and Technology. 28, 49-52. https://doi.org/10.1002/ceat.200407070

937 [72] Cui, F., 2012. Cold CANON: Anammox at low temperatures. The Netherlands: 938 Delft University of Technology. http://resolver.tudelft.nl/uuid:2bc15934-7e46-4d5e939 98a6-d8f7cfdf8d9e

940 [73] Bi, Z., Qiao, S., Zhou, J., Tang, X.,Zhang, J., 2014. Fast start-up of Anammox 941 process with appropriate ferrous iron concentration. Bioresource Technology. 170, 506942 512. https://doi.org/10.1016/j.biortech.2014.07.106

943 [74] Christensson, M., Ekstrom, S., Andersson Chan, A., Le Vaillant, E.,Lemaire, R., 944 2013. Experience from start-ups of the first ANITA Mox plants. Water Science and 945 Technology. 67, 2677-2684. https://doi.org/10.2166/wst.2013.156

946 [75] Jenkins, D.,Wanner, J., 2014. Activated Sludge - 100 Years and Counting. IWA 947 Publishing. https://doi.org/10.2166/9781780404943

948 [76] van Haandel, A.C.,van der Lubbe, J.G.M., 2012. Handbook of Biological 949 Wastewater Treatment. IWA Publishing. 950 https://books.google.com/books?id=rGX9sgEACAAJ 
951 [77] Khiewwijit, R., Temmink, H., Rijnaarts, H.,Keesman, K.J., 2015. Energy and 952 nutrient recovery for municipal wastewater treatment: How to design a feasible plant 953 layout? Environmental Modelling and Software. 68, 156-165.

\section{4 https://doi.org/10.1016/j.envsoft.2015.02.011}

955 [78] Verstraete, W.,Vlaeminck, S.E., 2011. ZeroWasteWater: short-cycling of 956 wastewater resources for sustainable cities of the future. International Journal of 957 Sustainable Development \& World Ecology. 18, 253-264. 958 https://doi.org/10.1080/13504509.2011.570804

959 [79] Vaccari, M., Foladori, P., Nembrini, S.,Vitali, F., 2018. Benchmarking of energy 960 consumption in municipal wastewater treatment plants - a survey of over 200 plants in 961 Italy. Water Science and Technology. 77, 2242-2252. 962 https://doi.org/10.2166/wst.2018.035

963 [80] Fitzsimons, L., Clifford, E., McNamara, G., Doherty, E., Phelan, T., Horrigan, M., 964 Delauré, Y.,Corcoran, B., 2016. Increasing Resource Efficiency in Wastewater 965 Treatment Plants. Environmental Protection Agency, Johnstown Castle, Ireland. 966 https://www.researchgate.net/publication/303974985 Increasing Resource Efficienc $967 \quad \mathrm{y}$ in Wastewater Treatment Plants

968 [81] Gurung, K., Tang, W.Z.,Sillanpää, M., 2018. Correction to: Unit Energy 969 Consumption as Benchmark to Select Energy Positive Retrofitting Strategies for 970 Finnish Wastewater Treatment Plants (WWTPs): a Case Study of Mikkeli WWTP. 971 Environmental Processes. 5, 931-931. https://doi.org/10.1007/s40710-018-0340-5

972 [82] Del Pozo, R., Diez, V.,Beltran, S., 2000. Anaerobic pre-treatment of 973 slaughterhouse wastewater using fixed-film reactors. Bioresource Technology. 71, 143974 149. https://doi.org/10.1016/S0960-8524(99)90065-2 
975 [83] Latiffi, N.A.A., Mohamed, R.M.S.R., Apandi, N.M.,Tajuddin, R.M. Year.

976 Preliminary assessment of growth rates on different concentration of microalgae

977 scenedesmus sp. in industrial meat food processing wastewater. in MATEC Web of

978 Conferences. 2017. EDP Sciences. https://doi.org/10.1051/matecconf/201710306010

979 [84] Vu, T., Bach, Q.D., Pham, H.B., Do, T.A.,Do, Q., 2017. The Performance of a

980 Gaslift MBR for Slaughterhouse Wastewater Treatment in $1 \mathrm{~m} 3 /$ day Scale. Modern

981 Environmental Science and Engineering. 03, 349-354.

982 https://pdfs.semanticscholar.org/2263/f924843e6487cbcafc6c8e9b4508ca5f2e96.pdf?

$983 \_\mathrm{ga}=2.158854392 .352607616 .1602798023-98483532.1585087819$

984 [85] Rajakumar, R.,Meenambal, T., 2008. Comparative Study on Start-Up

985 Performance of HUASB and AF Reactors Treating Poultry Slaughterhouse

986 Wastewater. International Journal of Environmental Research. 2, 401-410.

987 https://ijer.ut.ac.ir/article_221_026486e1ef33561c63ec2f49bd6981b4.pdf

988 [86] Yaakob, M.A., Mohamed, R.M.S.R., Al-Gheethi, A.A.S.,Kassim, A.H.M., 2018.

989 Characteristics of chicken slaughterhouse wastewater. Chemical Engineering

990 Transactions. 63, 637-642. https://doi.org/10.3303/CET1863107

991 [87] Ayoub, G.M., Hamzeh, A.,Semerjian, L., 2011. Post treatment of tannery

992 wastewater using lime/bittern coagulation and activated carbon adsorption.

993 Desalination. 273, 359-365. https://doi.org/10.1016/j.desal.2011.01.045

994 [88] Doble, M.,Kumar, A., 2005. Biotreatment of Industrial Effluents. Elsevier

995 Science. https://books.google.com/books?id=4qsNn-DZPScC

996 [89] Durai, G., Rajamohan, N., Karthikeyan, C.,Rajasimman, M., 2010. Kinetics

997 studies on biological treatment of tannery wastewater using mixed culture. International

998 Journal of Chemical and Biological Engineering. 3, 105-109. 
$1000 \quad$ pdf

1001 [90] Yigit, N.O., Uzal, N., Koseoglu, H., Harman, I., Yukseler, H., Yetis, U.,

1002 Civelekoglu, G.,Kitis, M., 2009. Treatment of a denim producing textile industry

1003 wastewater using pilot-scale membrane bioreactor. Desalination. 240, 143-150.

1004 https://doi.org/10.1016/j.desal.2007.11.071

1005 [91] Tara, N., Arslan, M., Hussain, Z., Iqbal, M., Khan, Q.M.,Afzal, M., 2019. On-site

1006 performance of floating treatment wetland macrocosms augmented with dye-degrading

1007 bacteria for the remediation of textile industry wastewater. Journal of Cleaner

1008 Production. 217, 541-548. https://doi.org/10.1016/j.jclepro.2019.01.258

1009 [92] Meriç, S., Selçuk, H.,Belgiorno, V., 2005. Acute toxicity removal in textile

1010 finishing wastewater by Fenton's oxidation, ozone and coagulation-flocculation

1011 processes. $\quad$ Water $\quad$ Research. $\quad 39, \quad$ 1147-1153.

1012 https://doi.org/10.1016/j.watres.2004.12.021

1013 [93] Patel, H.,Vashi, R.T., 2015. Characterization and Treatment of Textile

1014 Wastewater. Elsevier Science. https://books.google.com/books?id=TvicBAAAQBAJ

1015 [94] Cavalcanti, P.F.F., 2003. Integrated application of the UASB reactor and ponds for 1016 domestic sewage treatment in tropical regions.

1017 https://library.wur.nl/WebQuery/wurpubs/320369

1018 [95] Qasim, S.R.,Zhu, G., 2018. Wastewater Treatment and Reuse: Theory and Design

1019 Examples. Taylor \& Francis, CRC Press. https://books.google.com/books?id=-

$1020 \quad$ kTnAQAACAAJ

1021 [96] Davis, M.L., 2010. Water and wastewater engineering: design principles and 1022 practice. McGraw-Hill Education. 
1023 [97] Kabouris, J.C., Tezel, U., Pavlostathis, S.G., Engelmann, M., Dulaney, J.A., Todd, 1024 A.C.,Gillette, R.A., 2009. Mesophilic and thermophilic anaerobic digestion of 1025 municipal sludge and fat, oil, and grease. Water Environment Research. 81, 476-485. 1026 https://doi.org/10.2175/106143008X357192

1027 [98] Qiao, J.,Zhou, H., 2018. Modeling of energy consumption and effluent quality 1028 using density peaks-based adaptive fuzzy neural network. IEEE/CAA Journal of 1029 Automatica Sinica. 5, 968-976. https://doi.org/10.1109/JAS.2018.7511168

1030 [99] Foley, J., De Haas, D., Hartley, K.,Lant, P., 2010. Comprehensive life cycle 1031 inventories of alternative wastewater treatment systems. Water Research. 44, 16541032 1666. https://doi.org/10.1016/j.watres.2009.11.031

1033 [100] Garrido-Baserba, M., Reif, R., Molinos-Senante, M., Larrea, L., Castillo, A., 1034 Verdaguer, M.,Poch, M., 2016. Application of a multi-criteria decision model to select 1035 of design choices for WWTPs. Clean Technologies and Environmental Policy. 18, 1036 1097-1109. https://doi.org/10.1007/s10098-016-1099-X

1037 [101] Sun, Y., Garrido-Baserba, M., Molinos-Senante, M., Donikian, N.A., Poch, 1038 M.,Rosso, D., 2020. A composite indicator approach to assess the sustainability and 1039 resilience of wastewater management alternatives. Science of the Total Environment. 1040 725, 138286. https://doi.org/10.1016/j.scitotenv.2020.138286

1041 [102] Tusseau-Vuillemin, M.H., Dispan, J., Mouchel, J.M.,Servais, P., 2003.

1042 Biodegradable fraction of organic carbon estimated under oxic and anoxic conditions.

1043 Water Research. 37, 2242-2247. https://doi.org/10.1016/S0043-1354(02)00582-1

1044 [103] CEC, 1991. Council Directive of 21. May 1991 concerning urban waste water 1045 treatment (91/271/EEC). J. Eur. Commun. 34, 40. http://translation1046 centre.am/pdf/Translat/EU Direct/environment/Dir 91271 en.pdf 
1047 [104] CMEP, 1992. Discharge standard of water pollutants for meat packing industry 1048 GB 13457-92.

1049 [105] Wang, Z., Xue, M., Huang, K.,Liu, Z., 2011. Textile dyeing wastewater 1050 treatment. Advances in treating textile effluent. 5, 91-116.

1051 https://www.intechopen.com/books/advances-in-treating-textile-effluent/textile-

1052 dyeing-wastewater-treatment

1053 [106] CPCB, 1986. General standards for discharge of environmental pollutants part-a:

1054 Effluents. https://cpcb.nic.in/GeneralStandards.pdf

1055 [107] Buljan, J., Kral, I.,Clonfero, G., 2011. Introduction to treatment of tannery

1056 effluents. UNIDO, Vienna. https://www.unido.org/sites/default/files/2011-

$1057 \quad 11 /$ Introduction to treatment of tannery effluents $0 . p d f$

1058 [108] Rajaganesh, K., Sumedha, N.C.,Ameer Basha, S., 2014. Characterization of 1059 textile dye effluent from Komarapalayam, Namakkal district, Tamilnadu, India. Indian 1060 Streams $\quad$ Research $\quad$ Journal. $2230-7850$.

1061 https://www.researchgate.net/publication/261285361_CHARACTERIZATION_OF_

1062 TEXTILE DYE EFFLUENT FROM KOMARAPALAYAM NAMAKKAL DIST

1063 RICT TAMILNADU INDIA

1064 [109] Caixeta, C.E.T., Cammarota, M.C.,Xavier, A.M.F., 2002. Slaughterhouse

1065 wastewater treatment: evaluation of a new three-phase separation system in a UASB

1066 reactor. Bioresource Technology. 81, 61-69. https://doi.org/10.1016/S0960-

$1067 \quad \underline{8524(01) 00070-0}$

1068 [110] Torkian, A., Eqbali, A.,Hashemian, S.J., 2003. The effect of organic loading rate 1069 on the performance of UASB reactor treating slaughterhouse effluent. Resources, 1070 Conservation and Recycling. 40, 1-11. https://doi.org/10.1016/S0921-3449(03)00021$1071 \quad 1$ 
1072 [111] Musa, M.A., Idrus, S., Harun, M.R., Tuan Mohd Marzuki, T.F.,Abdul Wahab, 1073 A.M., 2020. A comparative study of biogas production from cattle slaughterhouse 1074 wastewater using conventional and modified Upflow Anaerobic Sludge Blanket 1075 (UASB) reactors. International journal of environmental research and public health. 17, 1076 283. https://doi.org/10.3390/ijerph17010283

1077 [112] Federation, W.E., 2017. Design of Water Resource Recovery Facilities, Manual 1078 of Practice No.8, Sixth Edition. McGraw-Hill Education.

1079 https://books.google.com/books?id=8Mw2DwAAQBAJ

1080 [113] Yang, L.B., Zeng, S.Y., Chen, J.N., He, M., Yang, W., 2010. Operational energy 1081 performance assessment system of municipal wastewater treatment plants. Water Sci 1082 Technol. 62, 1361-1370. https://doi.org/10.2166/wst.2010.394

1083 [114] Lackner, S., Gilbert, E.M., Vlaeminck, S.E., Joss, A., Horn, H.,van Loosdrecht, 1084 M.C., 2014. Full-scale partial nitritation/anammox experiences-an application survey. 1085 Water Research. 55, 292-303. https://doi.org/10.1016/j.watres.2014.02.032

1086 [115] Christensson, M., Ekström, S., Chan, A.A., Le Vaillant, E.,Lemaire, R., 2013. 1087 Experience from start-ups of the first ANITA Mox plants. Water Science and 1088 Technology. 67, 2677-2684. https://doi.org/10.2166/wst.2013.156

1089 [116] Garrido, J.M., Fdz-Polanco, M.,Fdz-Polanco, F., 2013. Working with energy and 1090 mass balances: a conceptual framework to understand the limits of municipal 1091 wastewater treatment. Water Science and Technology. 67, 2294-2301. 1092 https://doi.org/10.2166/wst.2013.124 
Figures

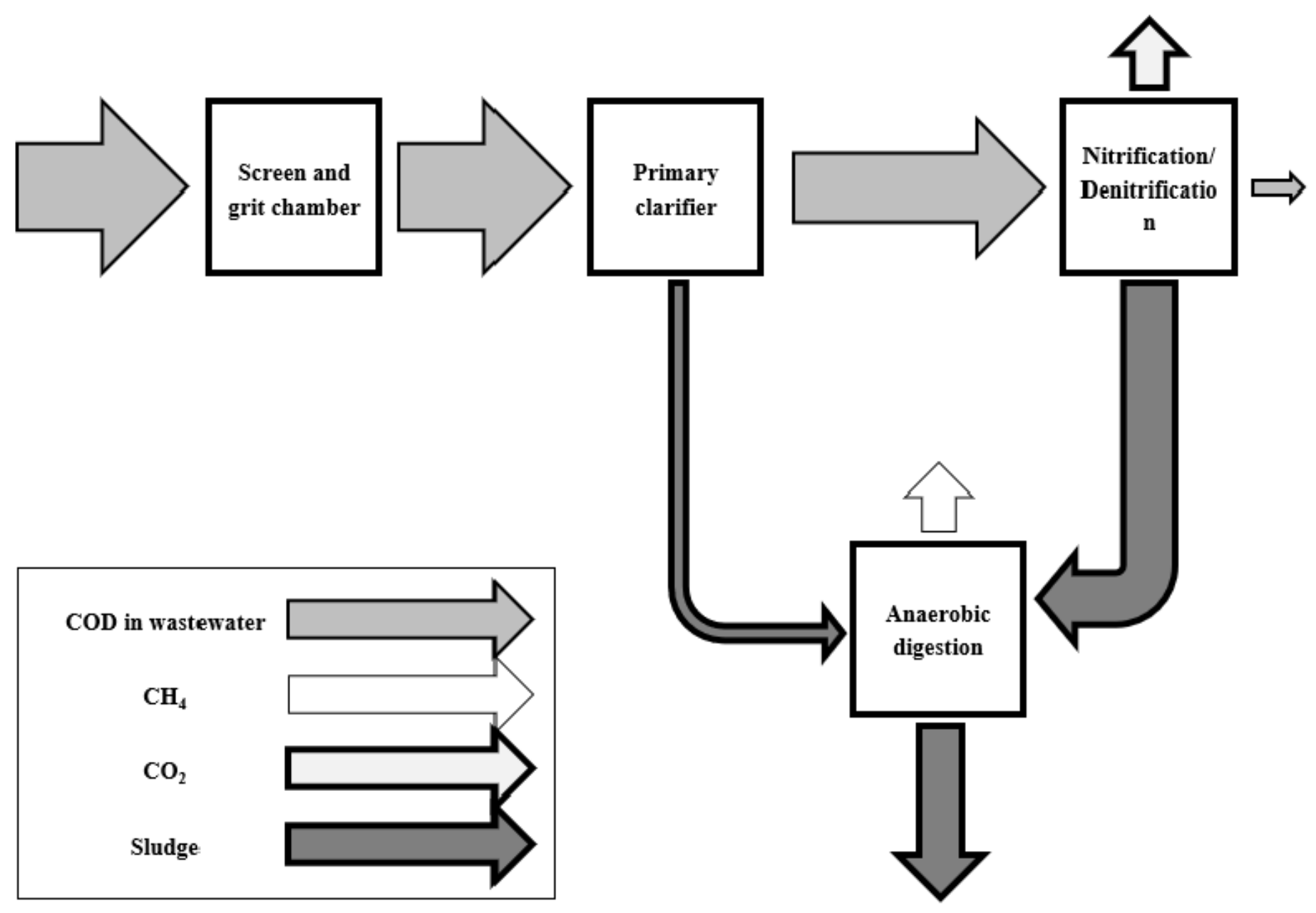

Figure 1

Schematic graphs of wastewater treatment system A- activated sludge process with nitrificationdenitrification 


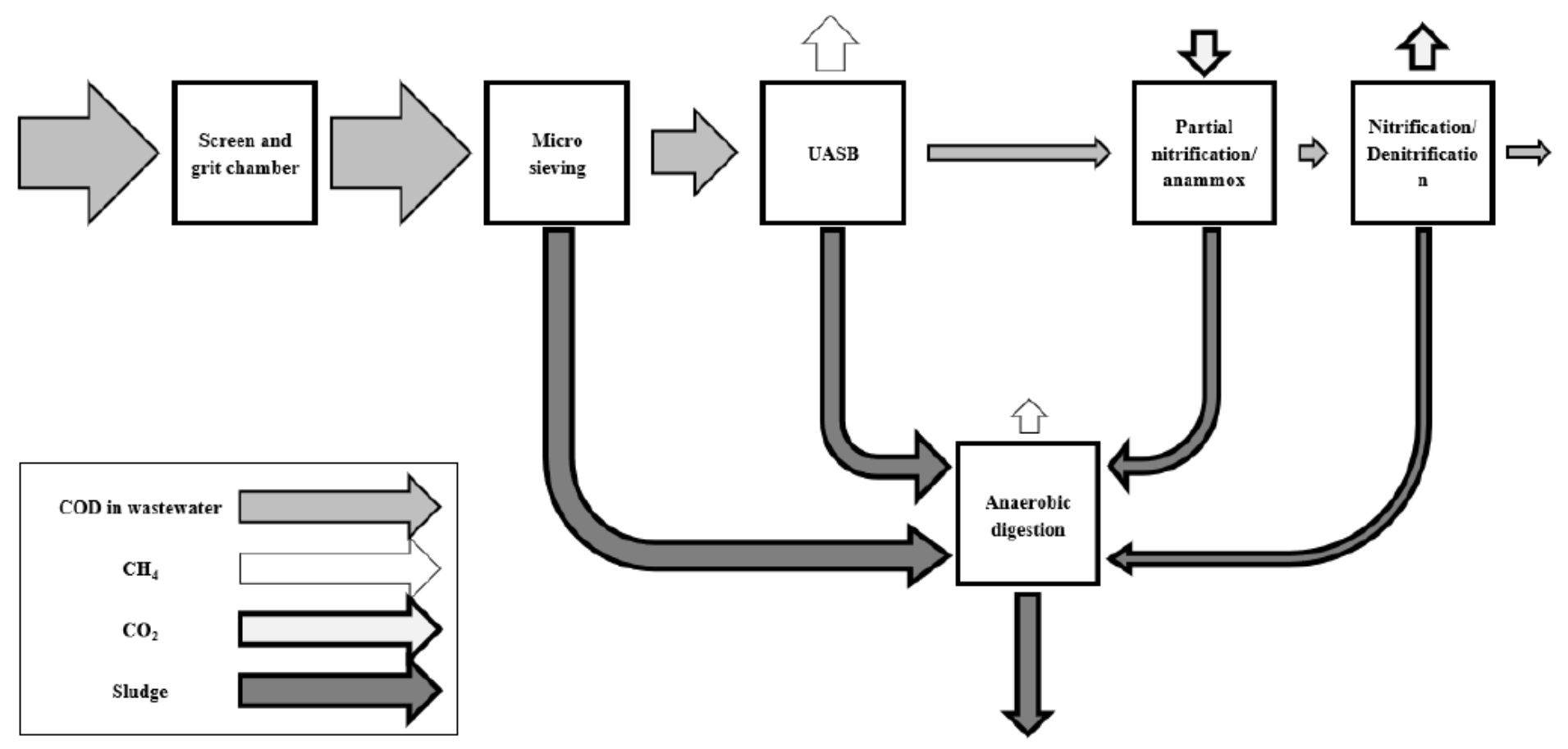

Figure 2

Scheme of wastewater treatment system B: UASB and anammox treatment 


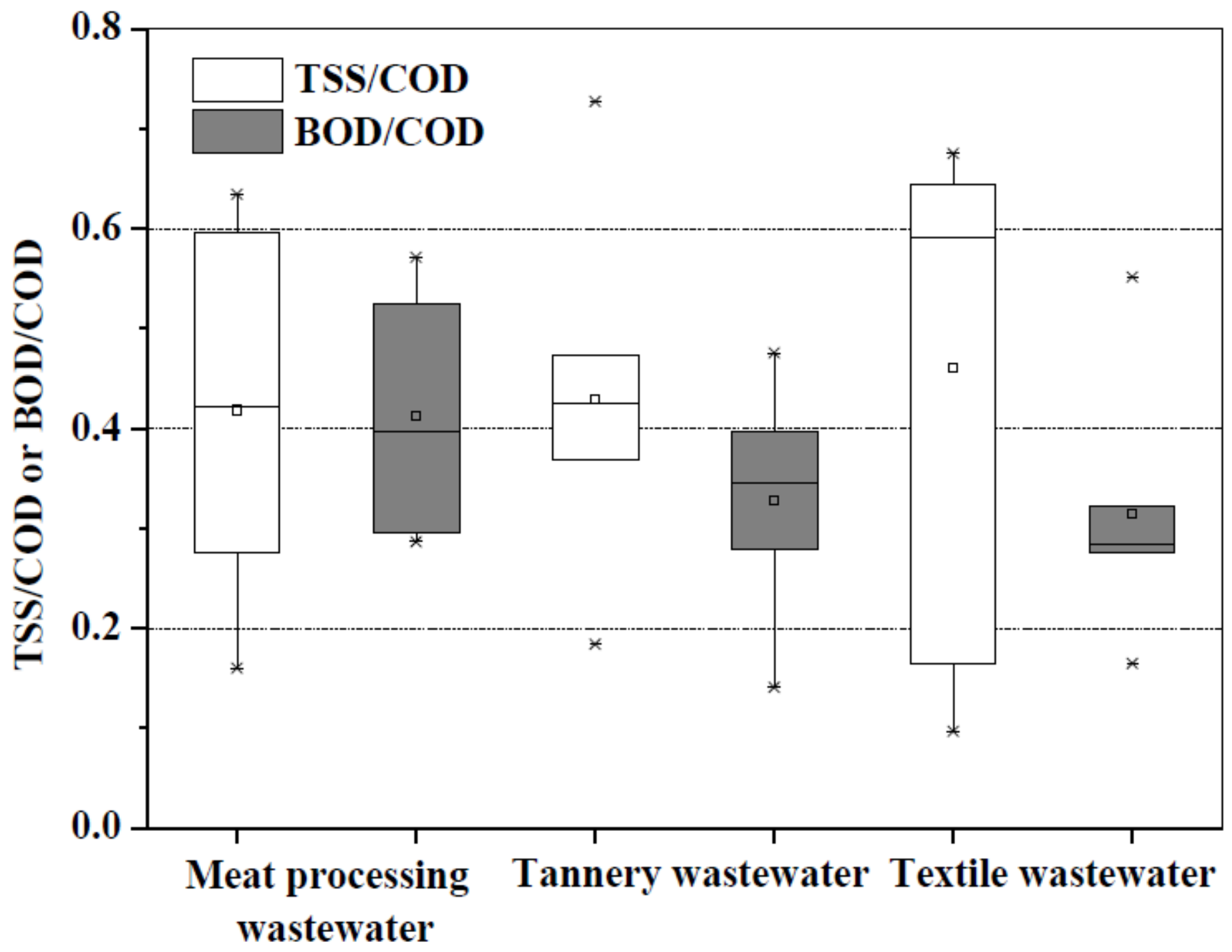

Figure 3

TSS/COD ratio and BOD/COD ratio for different industrial wastewater 


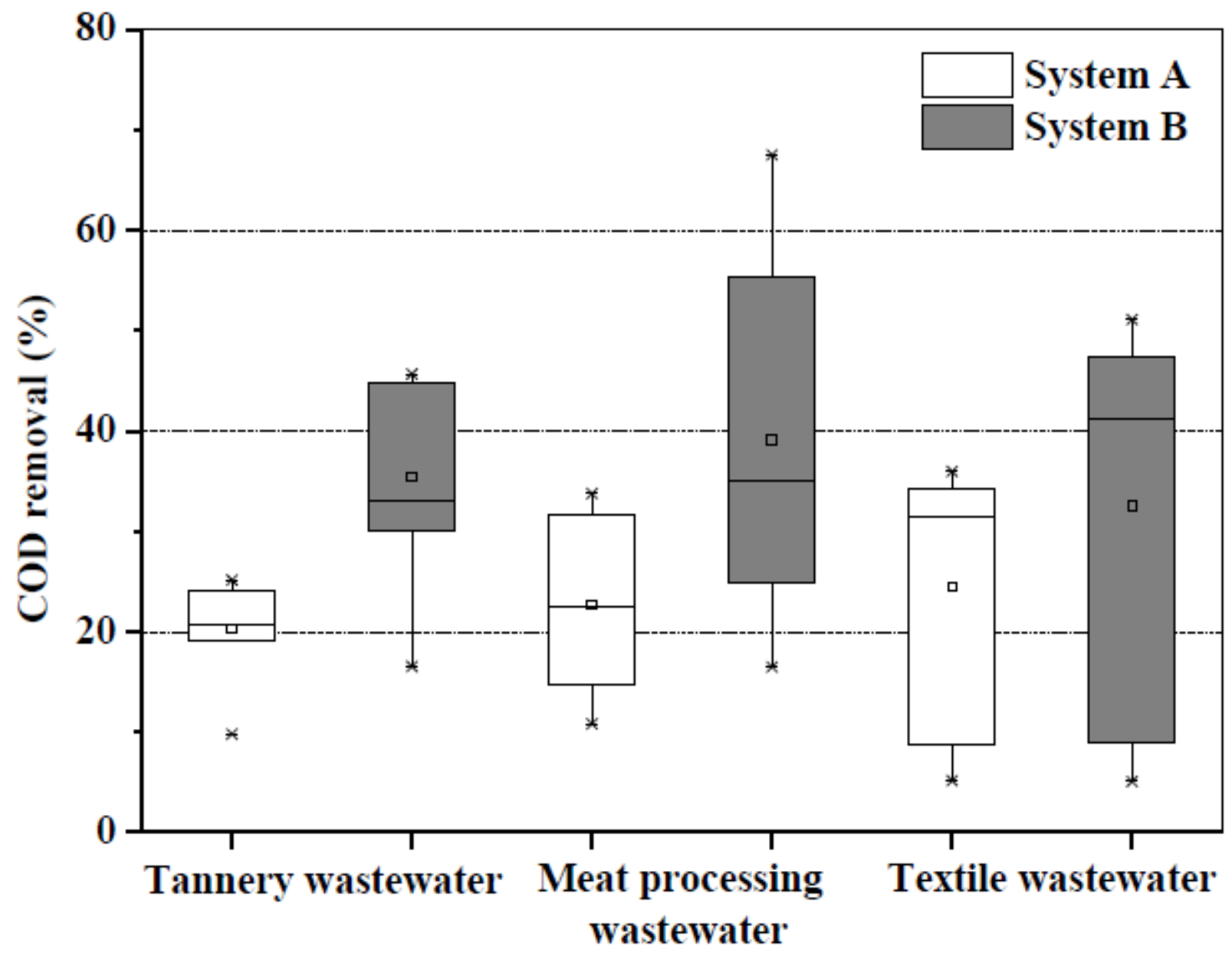

Figure 4

COD removal of primary treatment for different industrial wastewater 


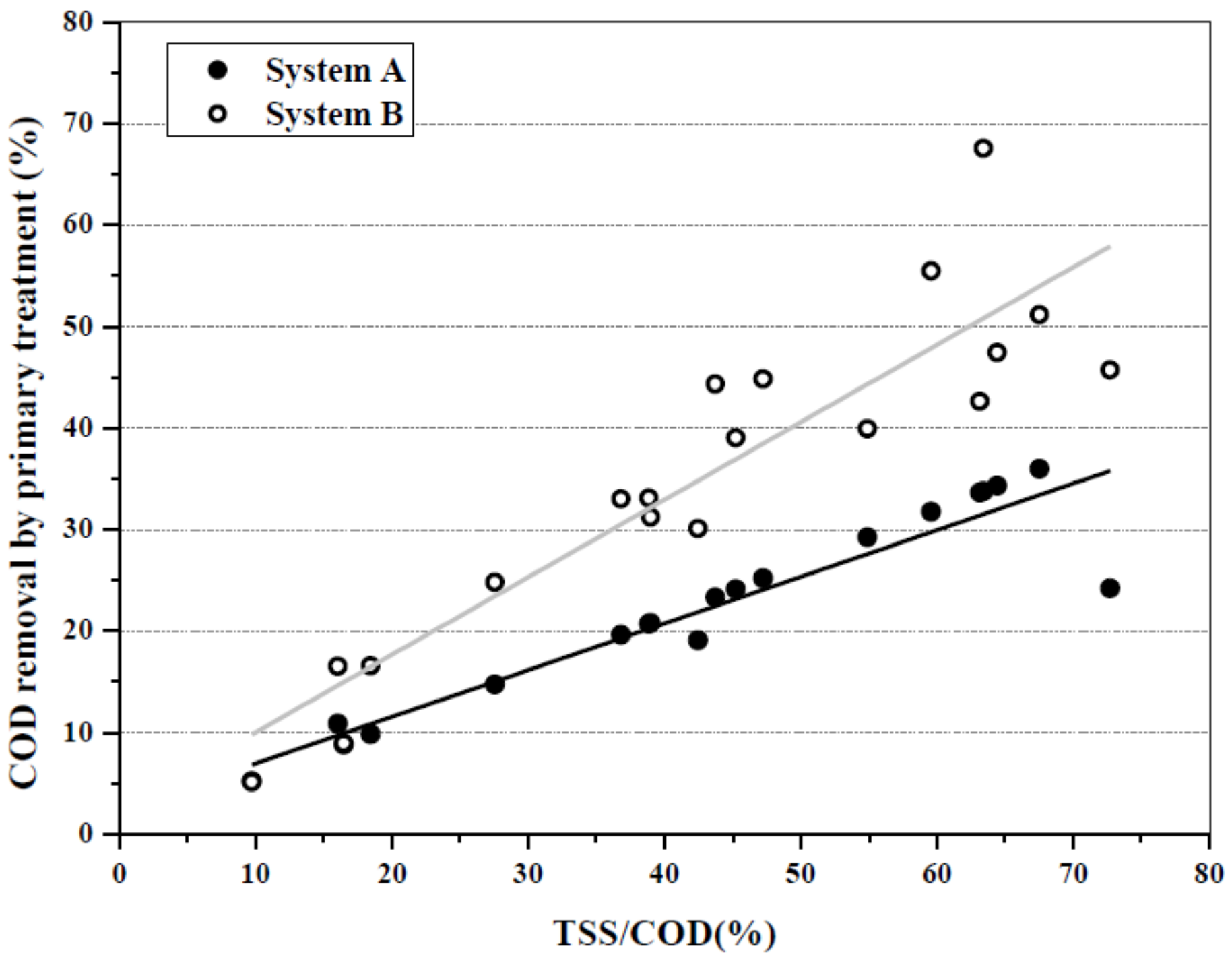

Figure 5

Variation of COD removal in primary treatment with TSS/COD ratio 


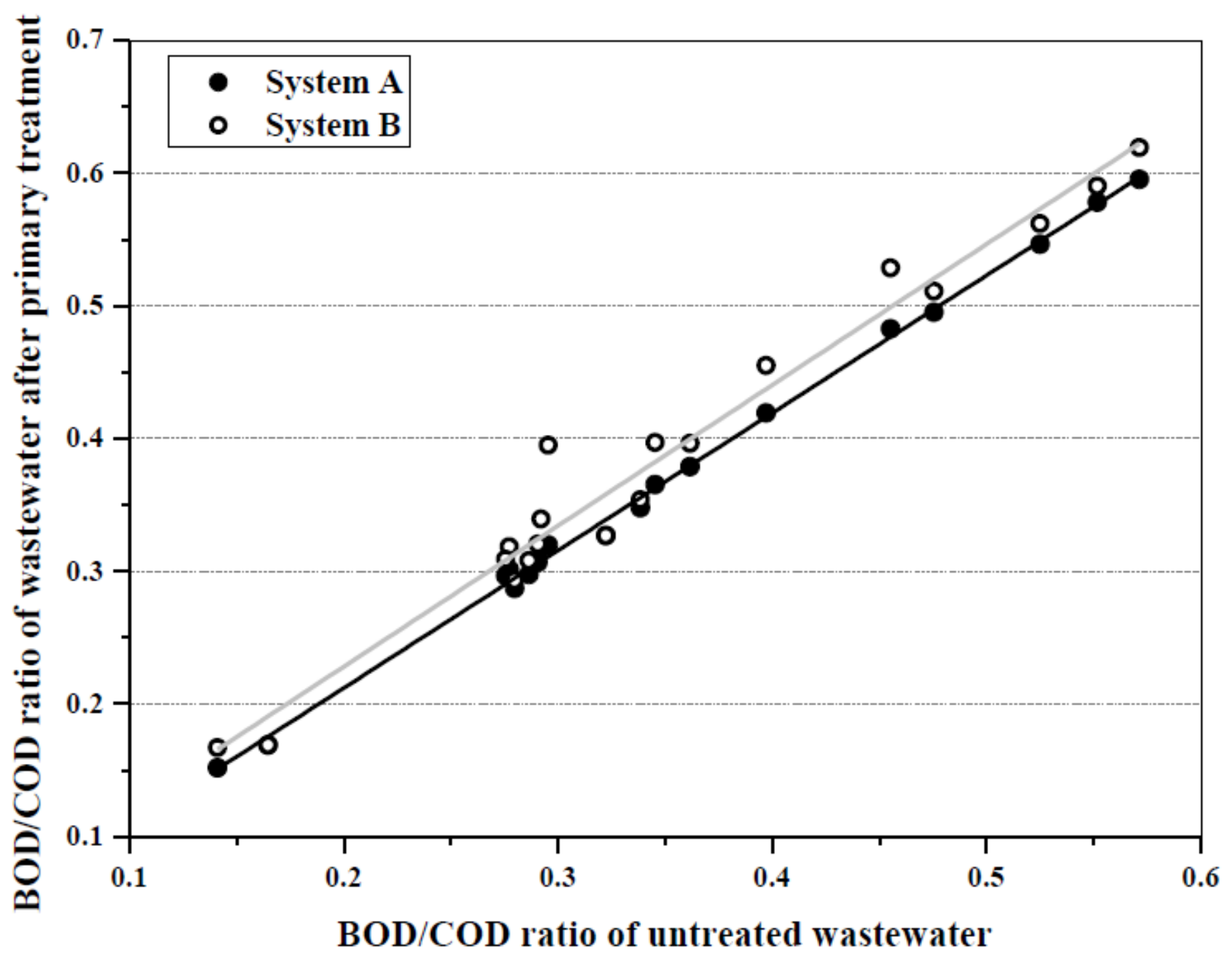

Figure 6

Variation of biodegradability after primary treatment 


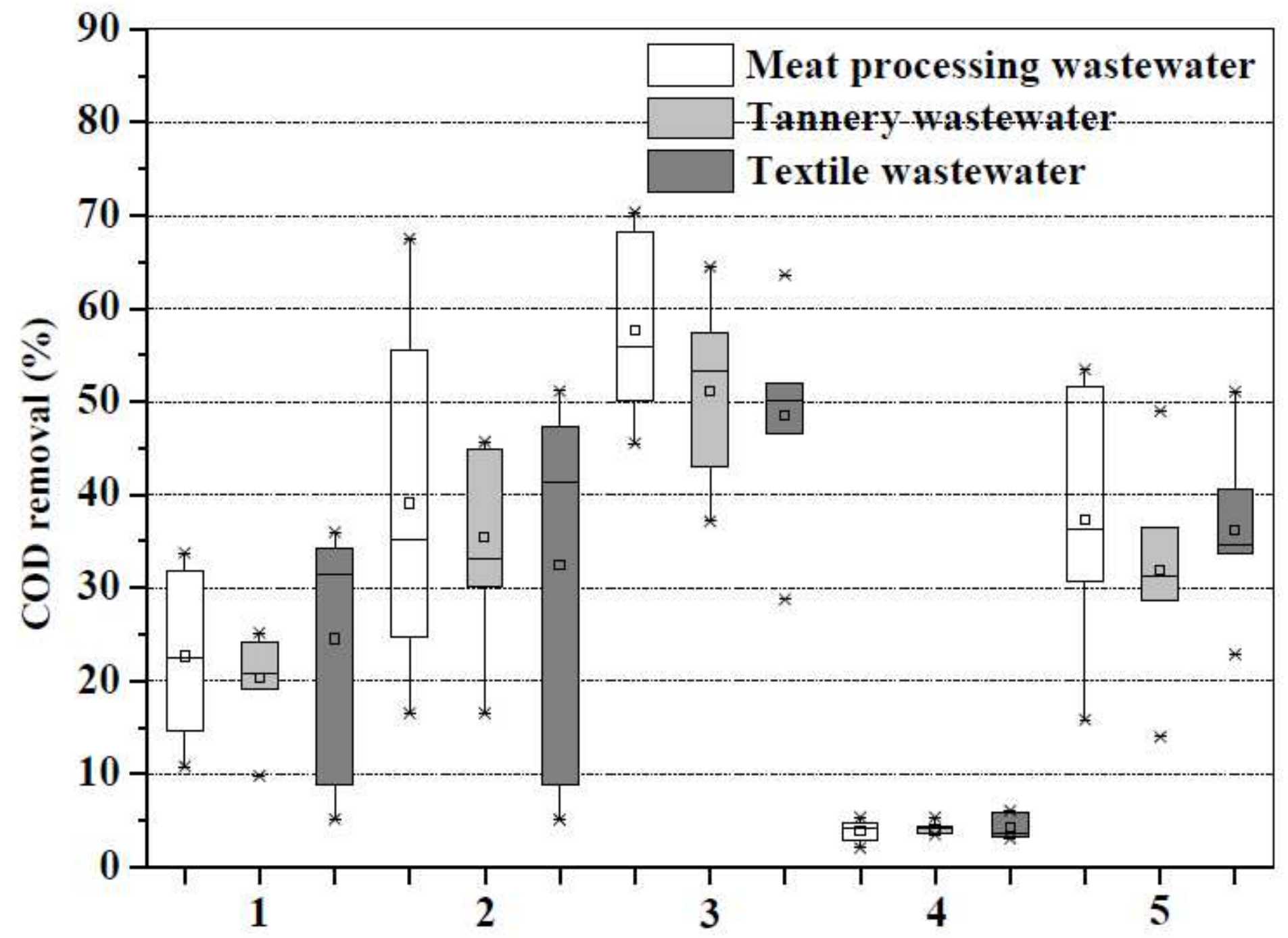

Figure 7

COD removal of primary and secondary treatment (1: Primary clarifier, 2: Micro sieving, 3: Aerobic treatment in system A, 4: Aerobic treatment in system $B, 5$ : UASB reactor.) 


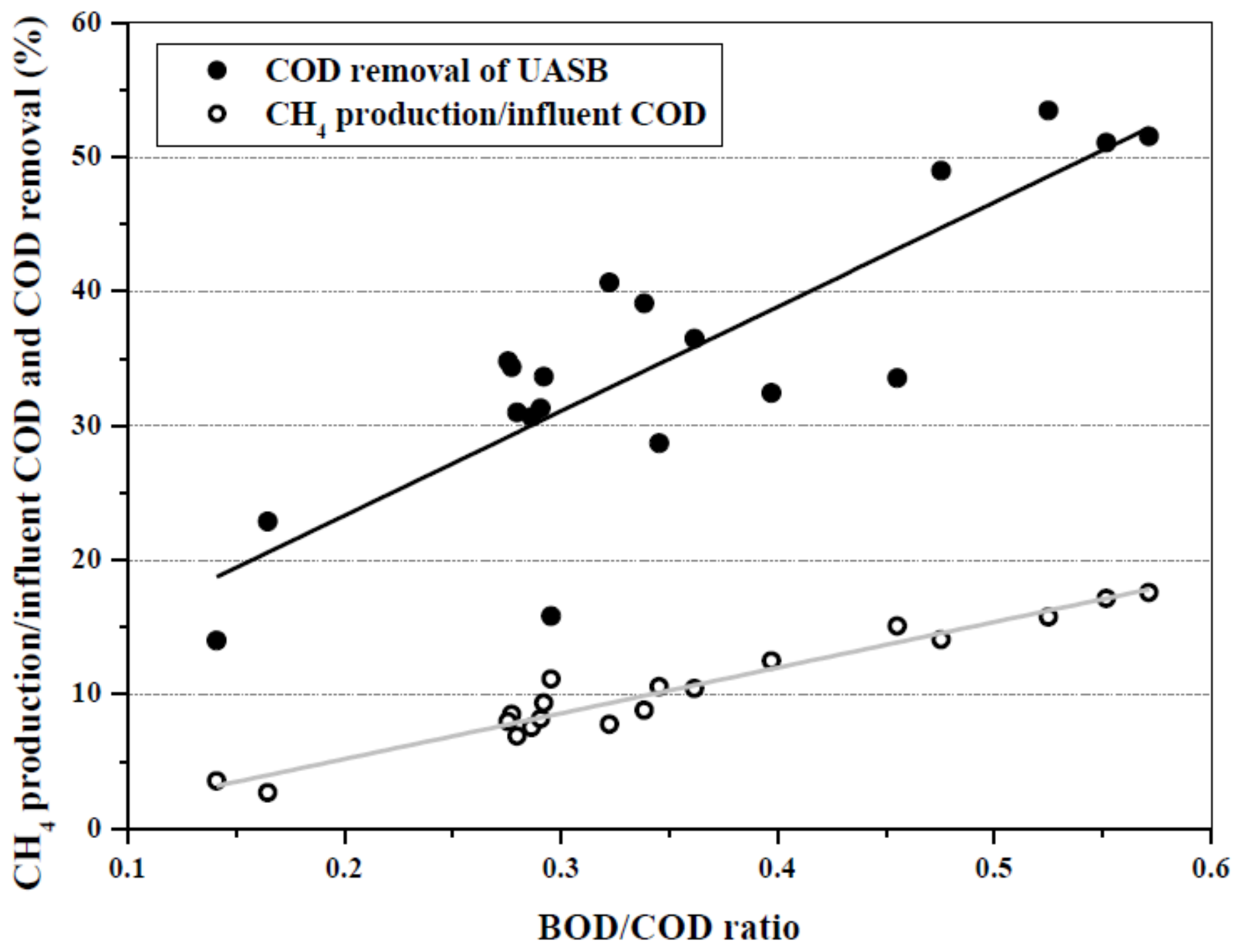

Figure 8

$\mathrm{CH} 4$ production/influent COD to UASB and COD removal of UASB reactor 


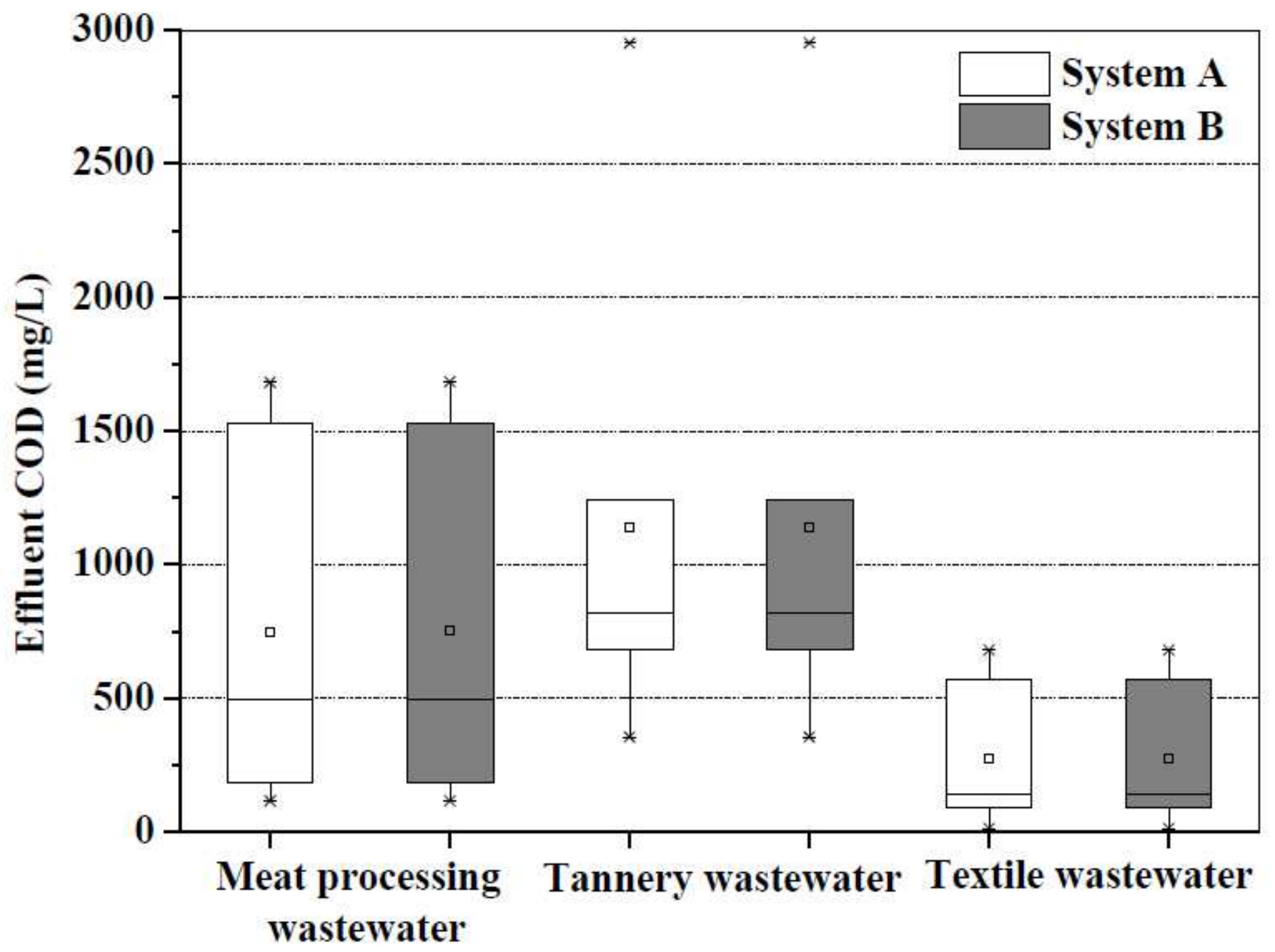

Figure 9

Effluent COD concentration of 3 industrial wastewater in two treatment systems 


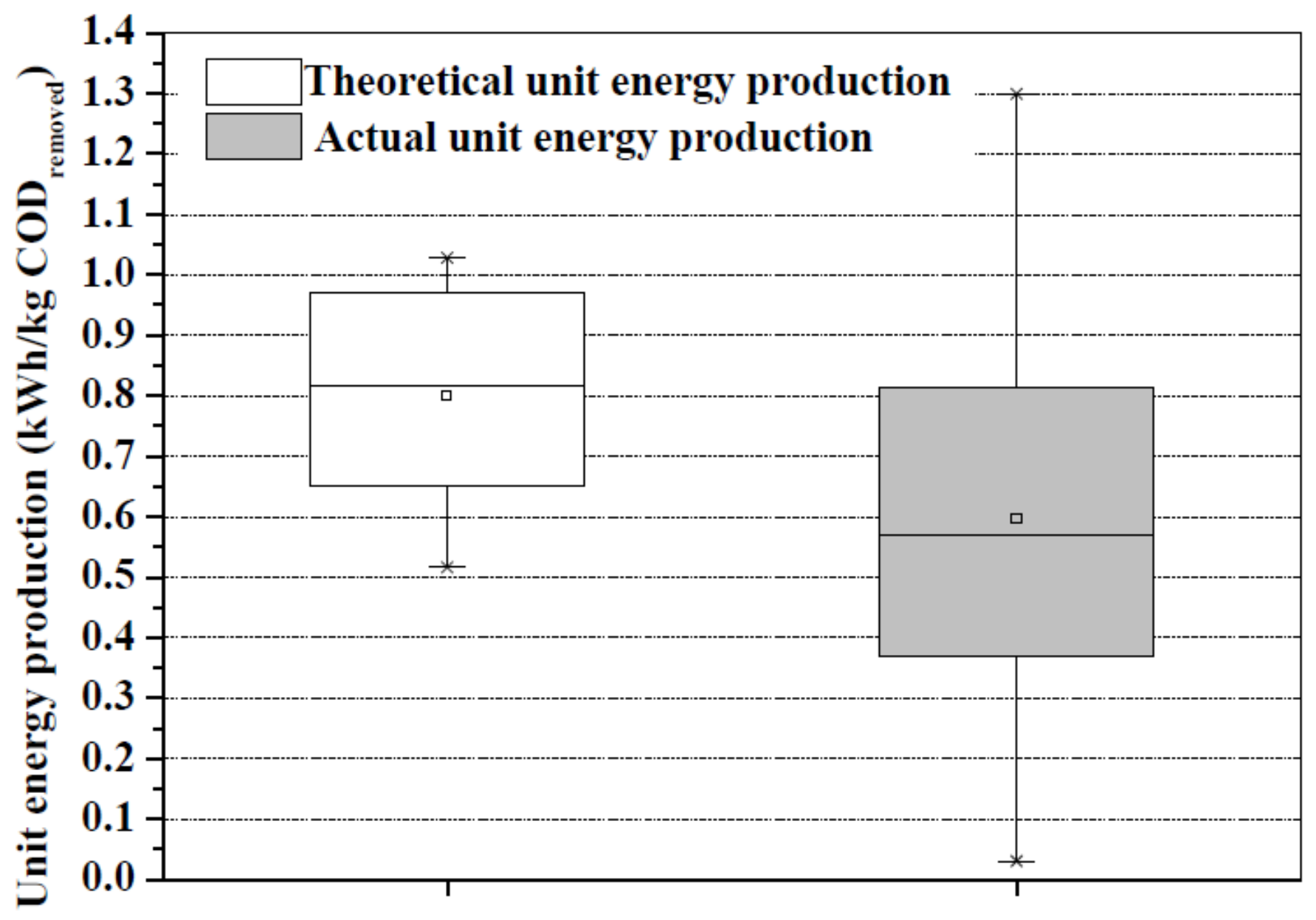

Food processing wastewater

Figure 10

Actual and Theoretical unit energy production of UASB 


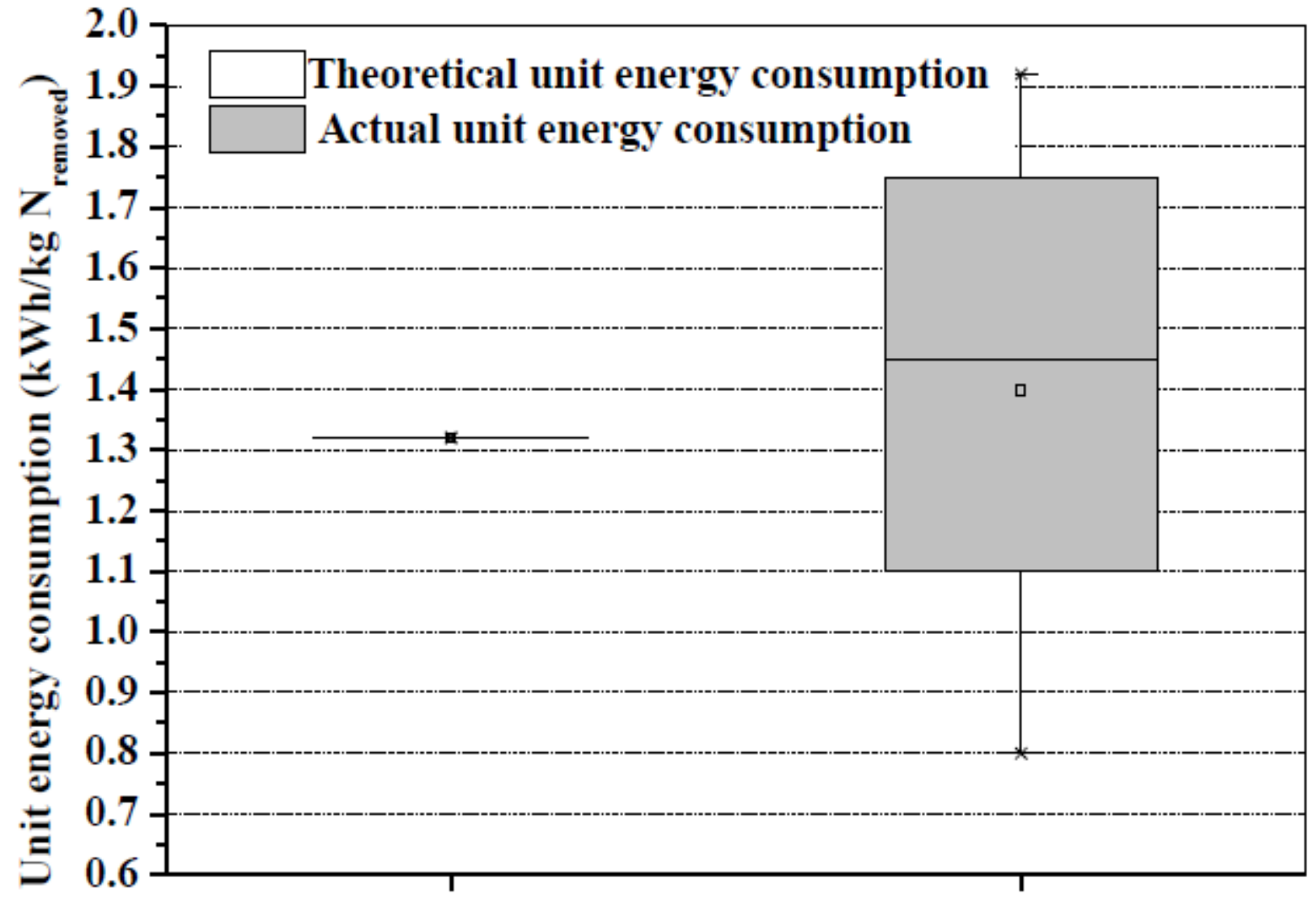

Food processing wastewater

Figure 11

Actual and Theoretical unit energy consumption of PN/A 


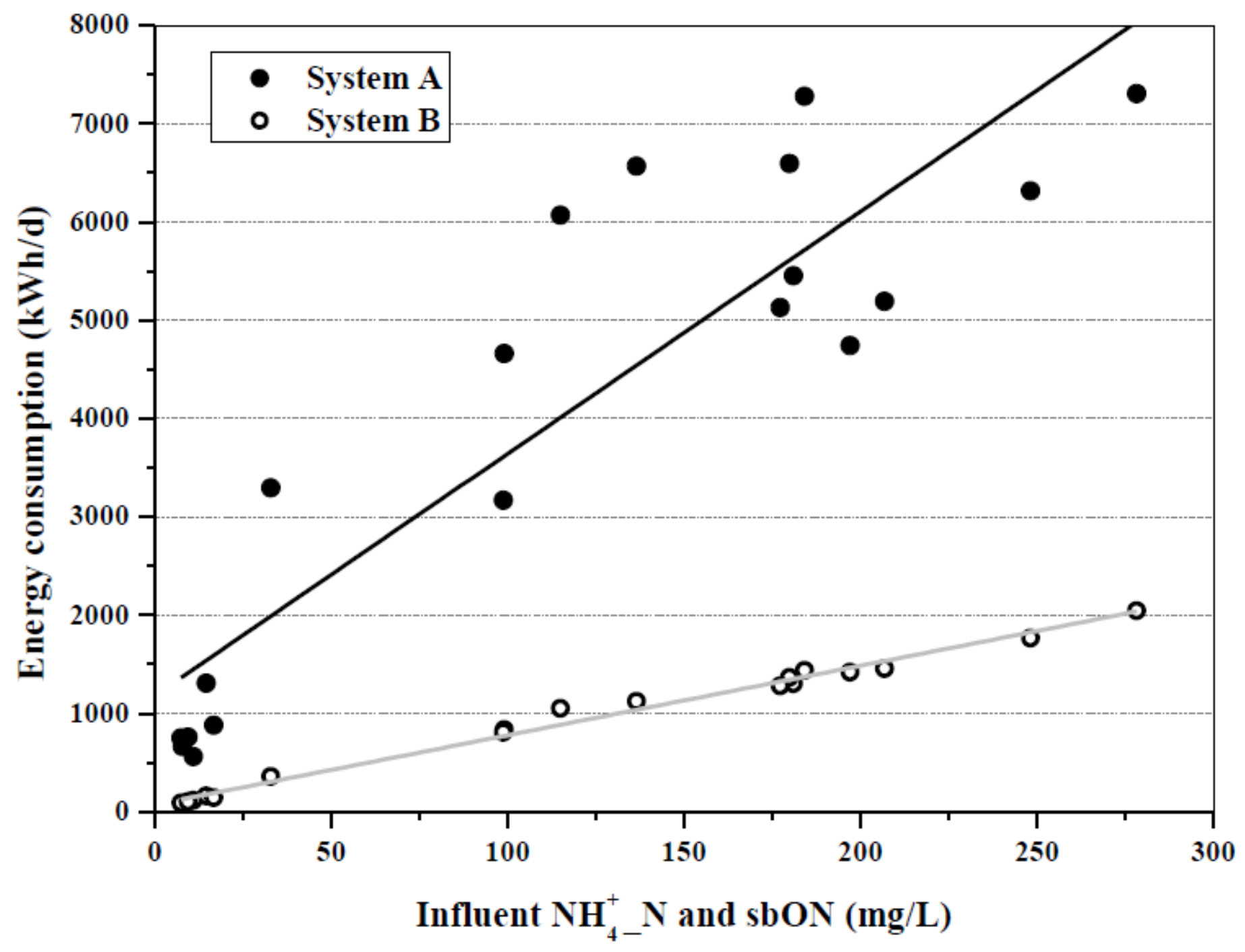

Figure 12

Electricity consumption and influent $\mathrm{NH} 4+\_\mathrm{N}$ and sbON 


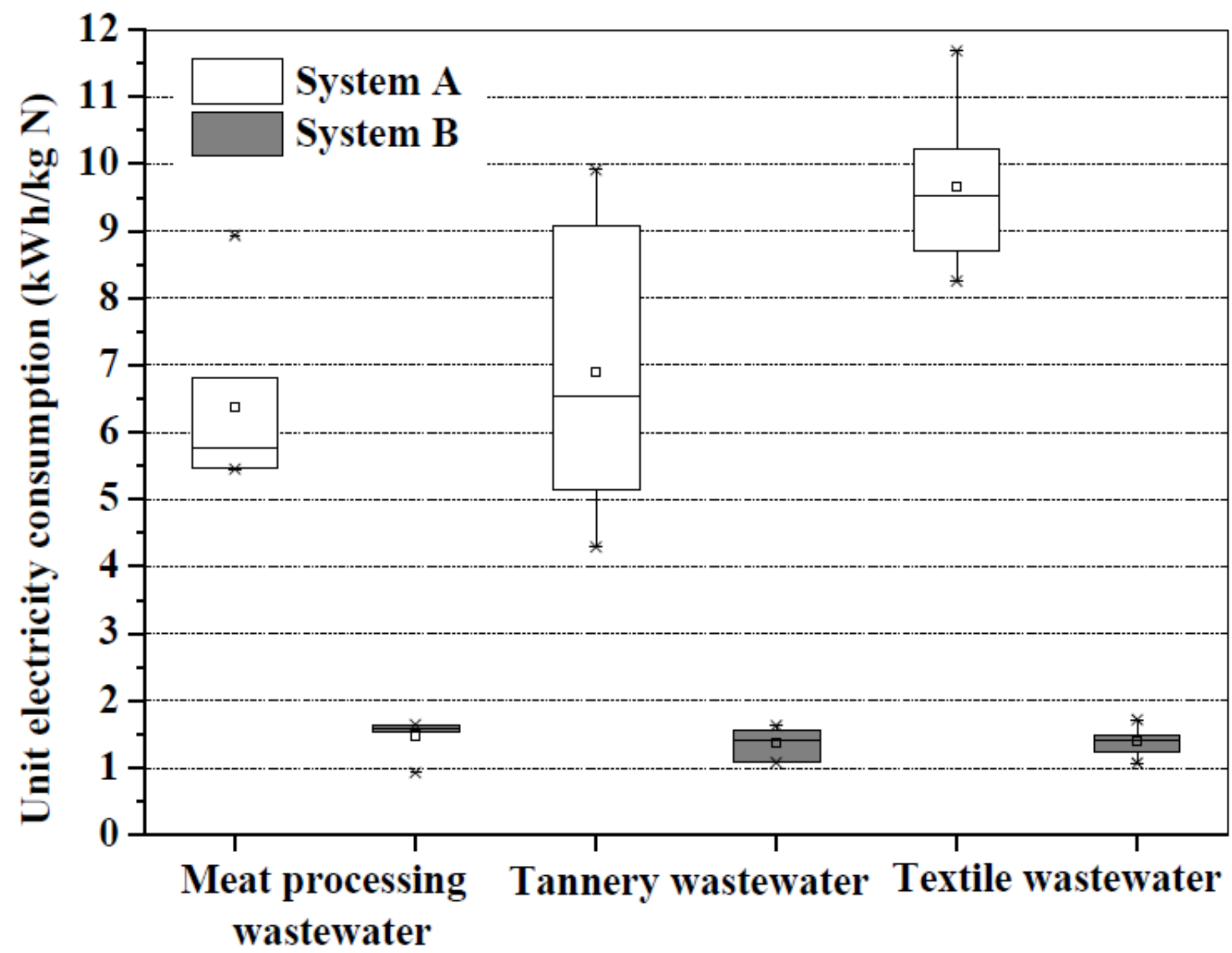

Figure 13

Unit electricity consumption 


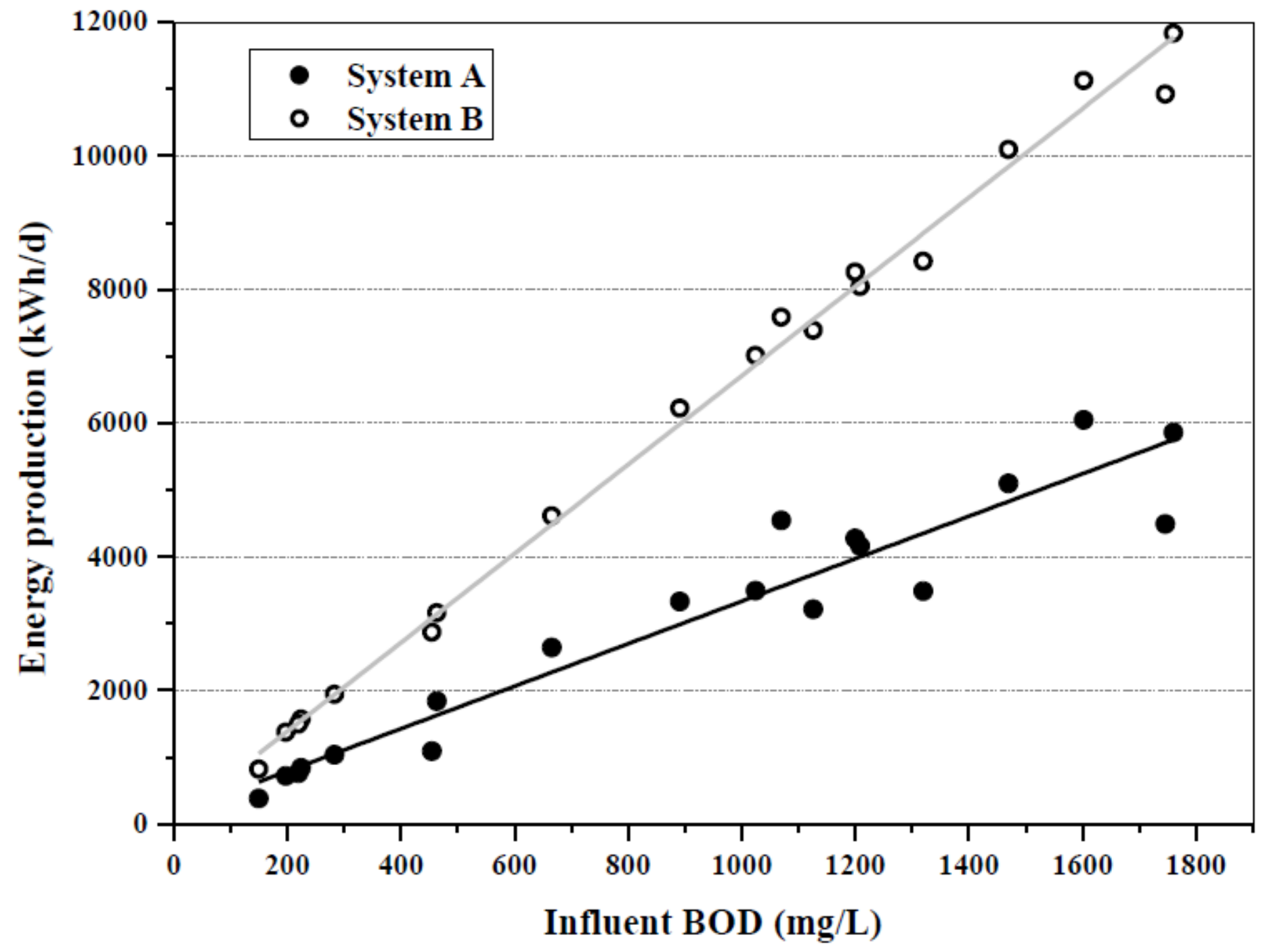

Figure 14

Electricity production and influent BOD 


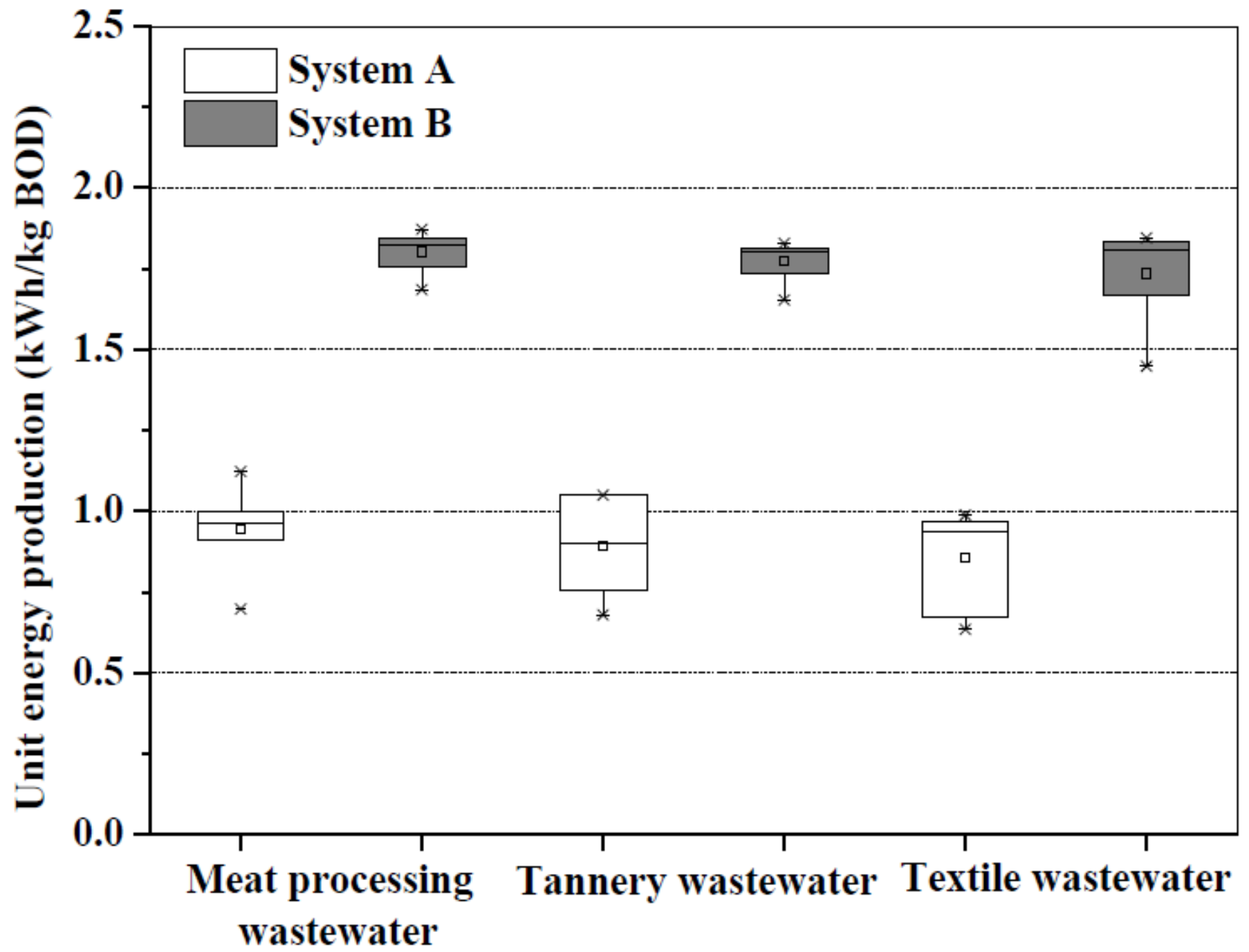

Figure 15

Unit electricity production 


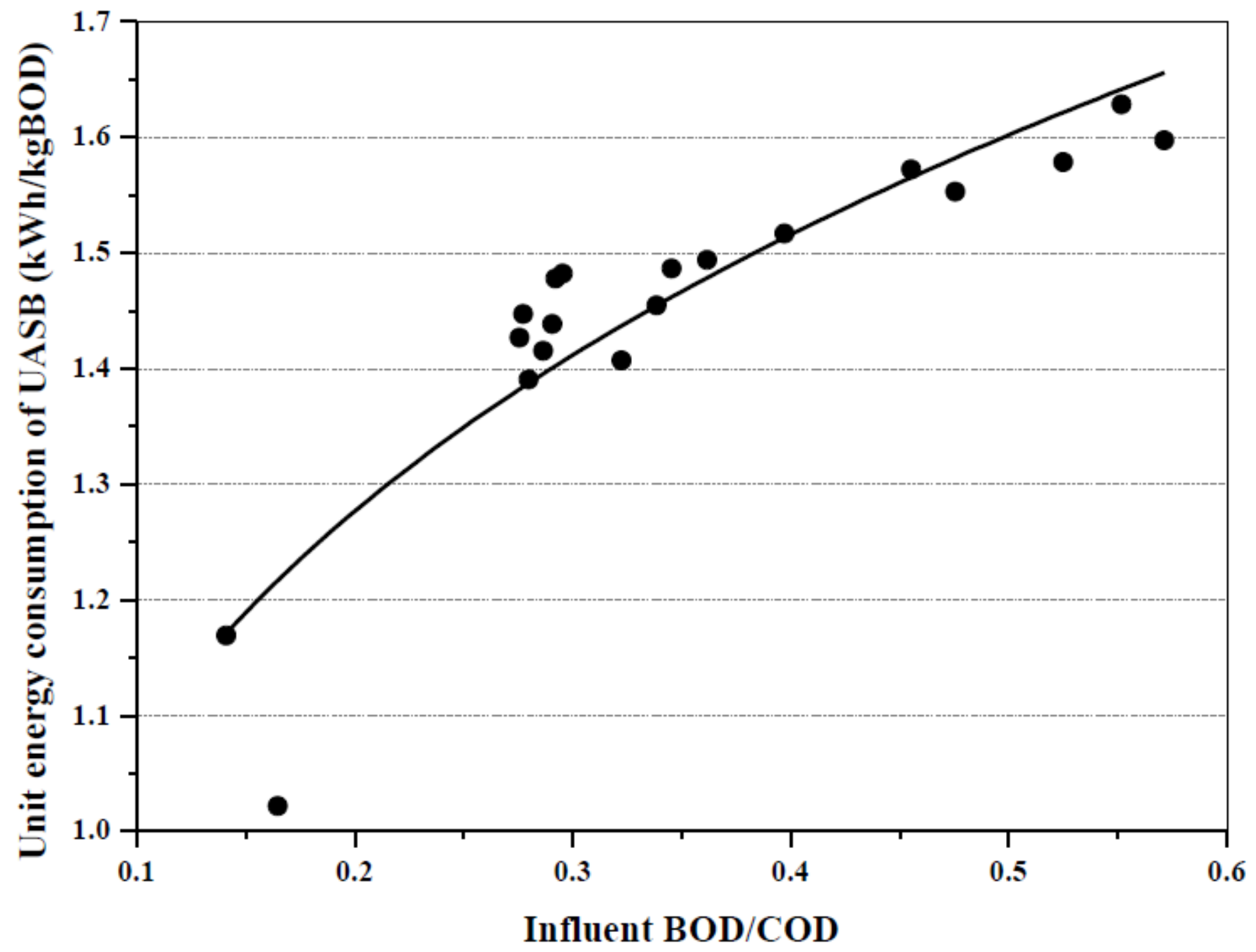

Figure 16

Unit energy production of UASB 


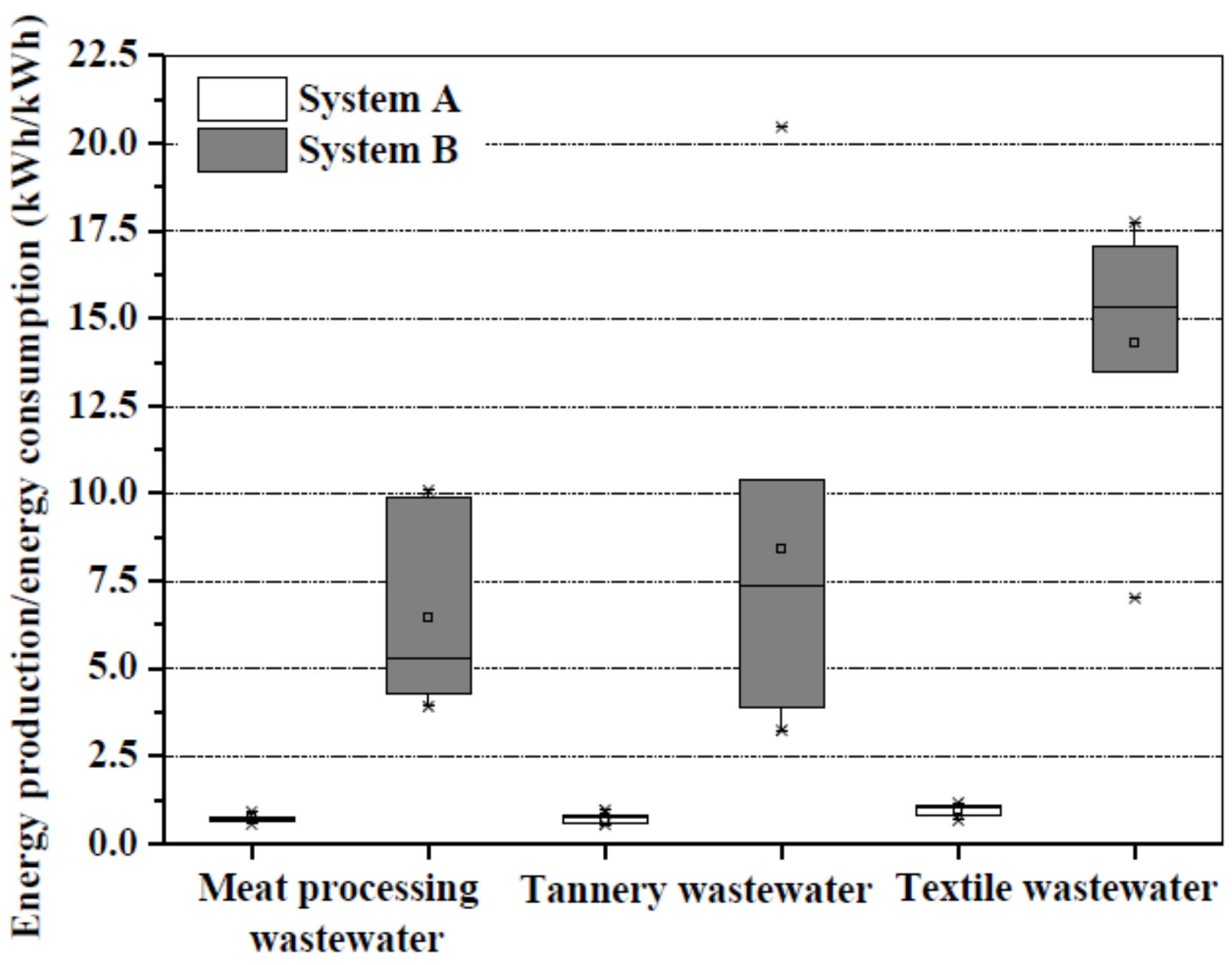

Figure 17

Energy recovery ratio of system $A$ and $B$ 


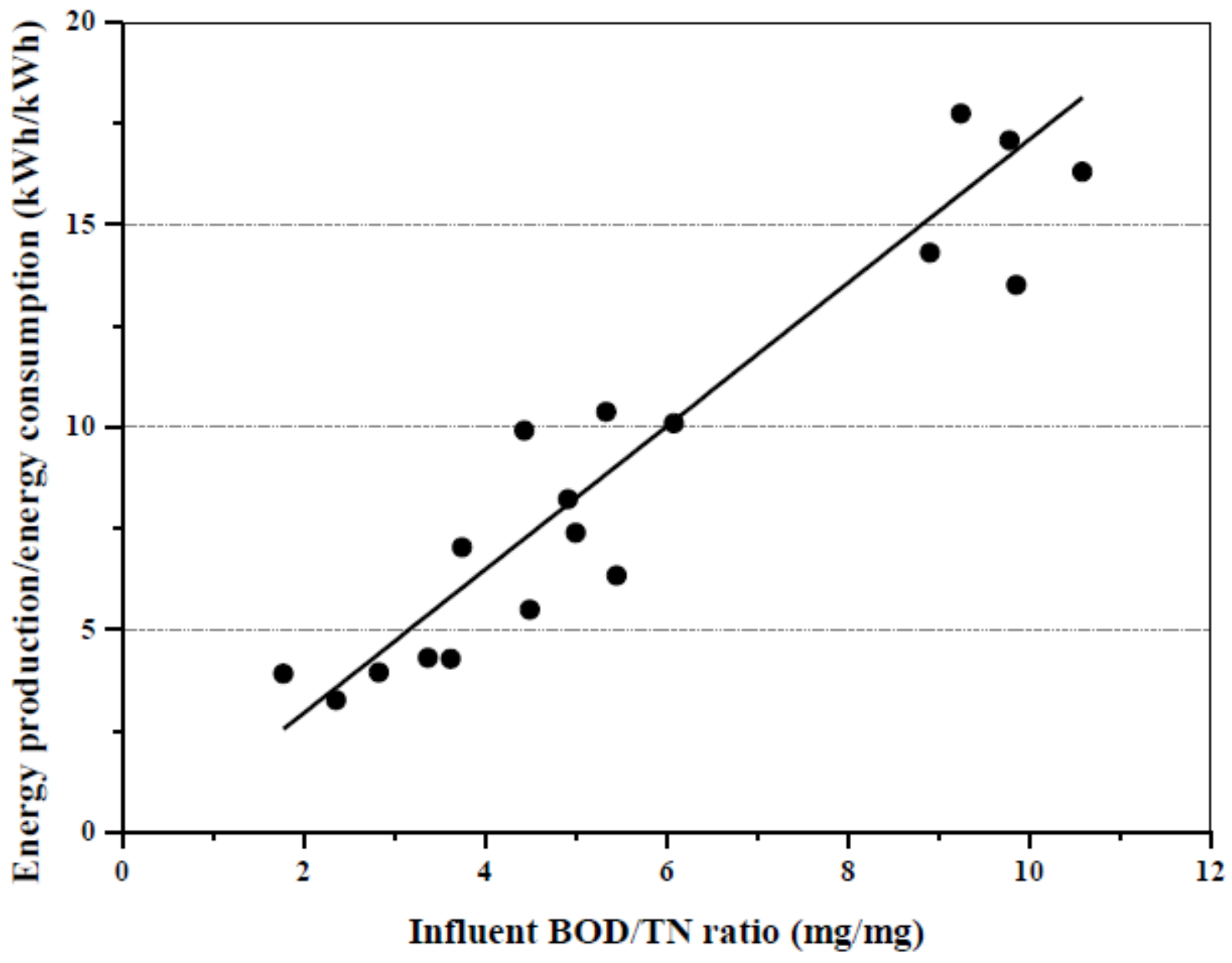

Figure 18

Energy recovery ratio as a function of daily influent BOD/ TN ratio in system B 


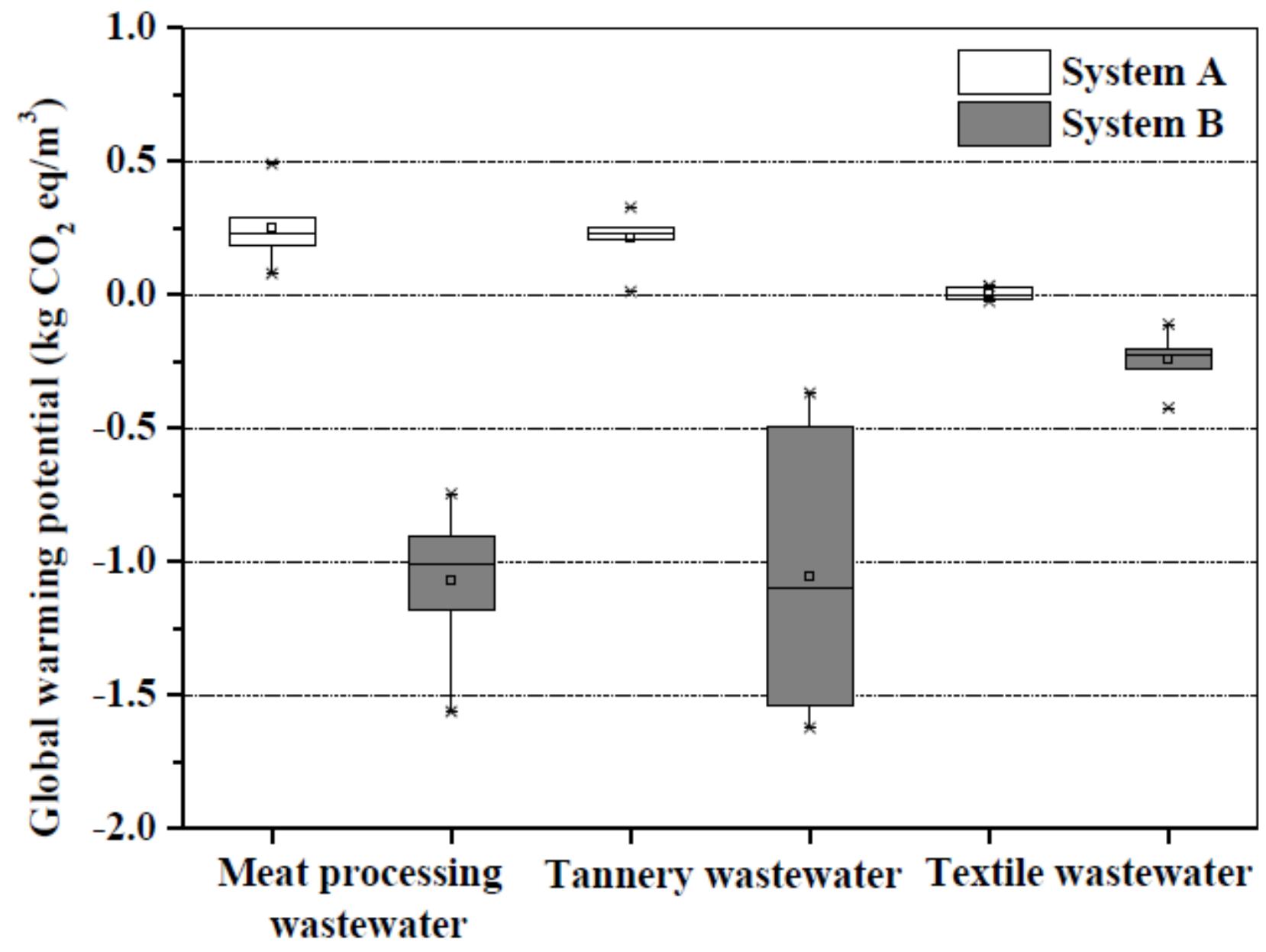

Figure 19

Global warming potential of 3 industrial wastewater in two treatment systems 


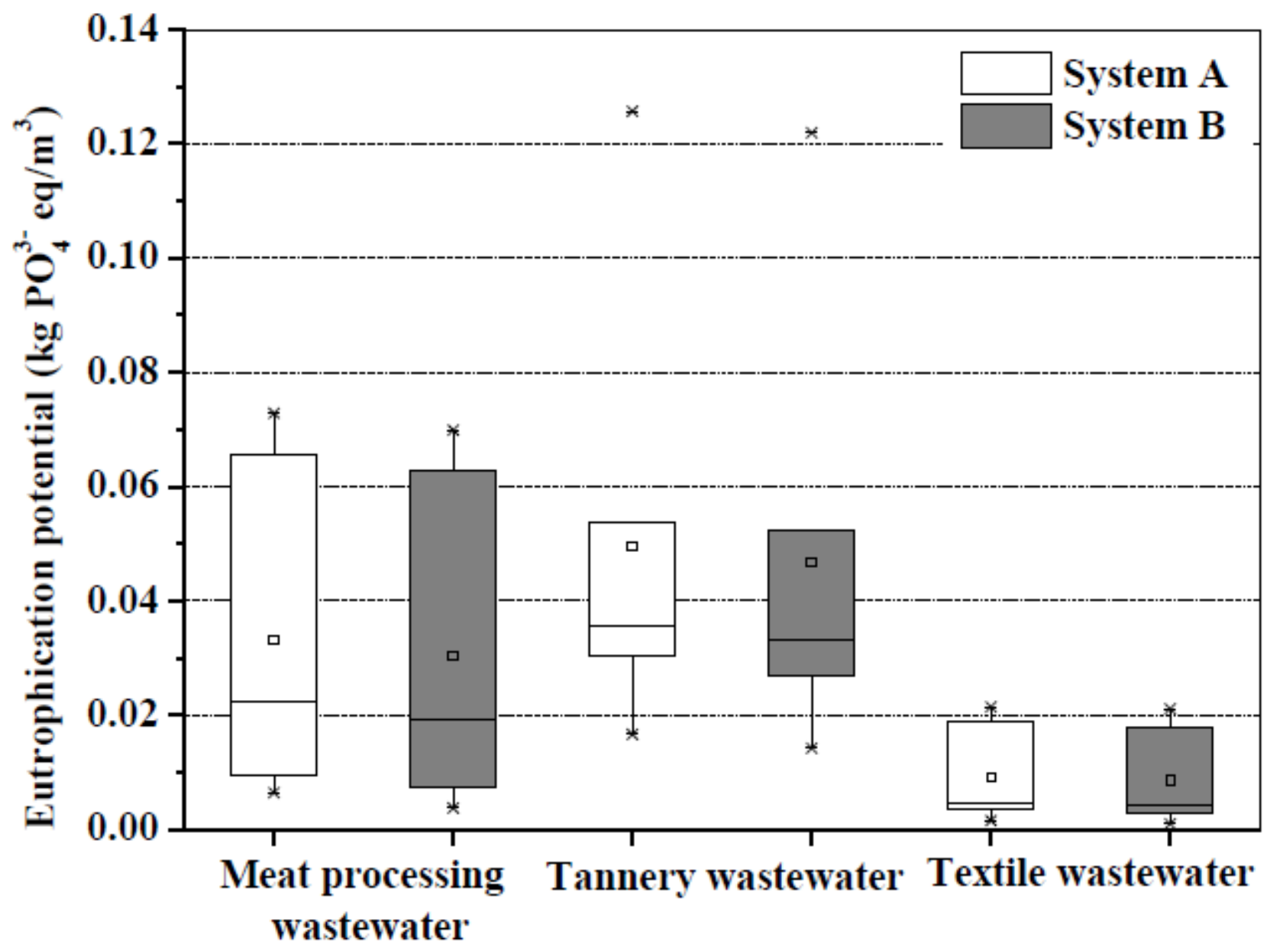

Figure 20

Eutrophication potential of three industrial wastewaters in two treatment systems 


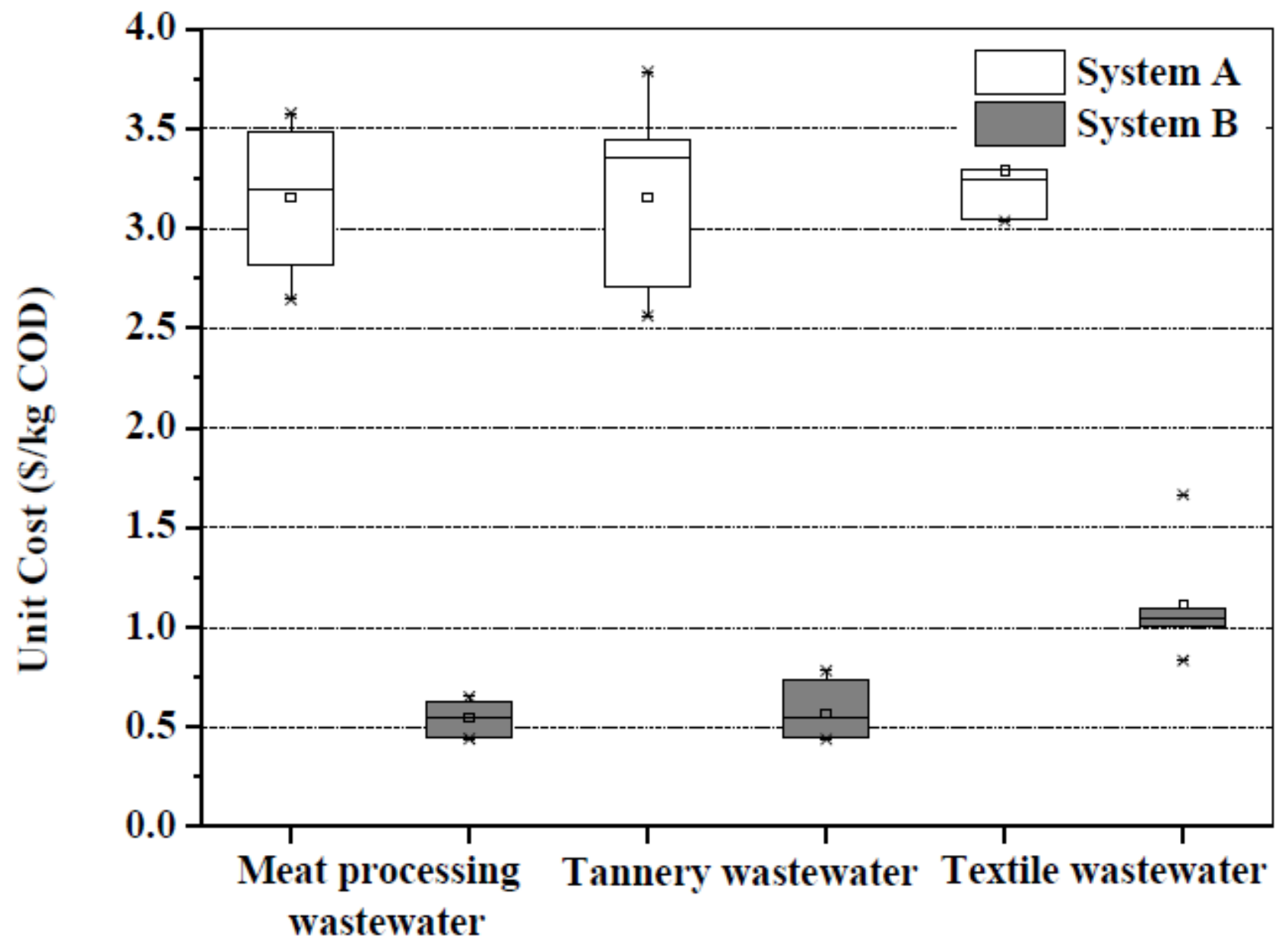

Figure 21

Unit cost of different industrial wastewater treatment 


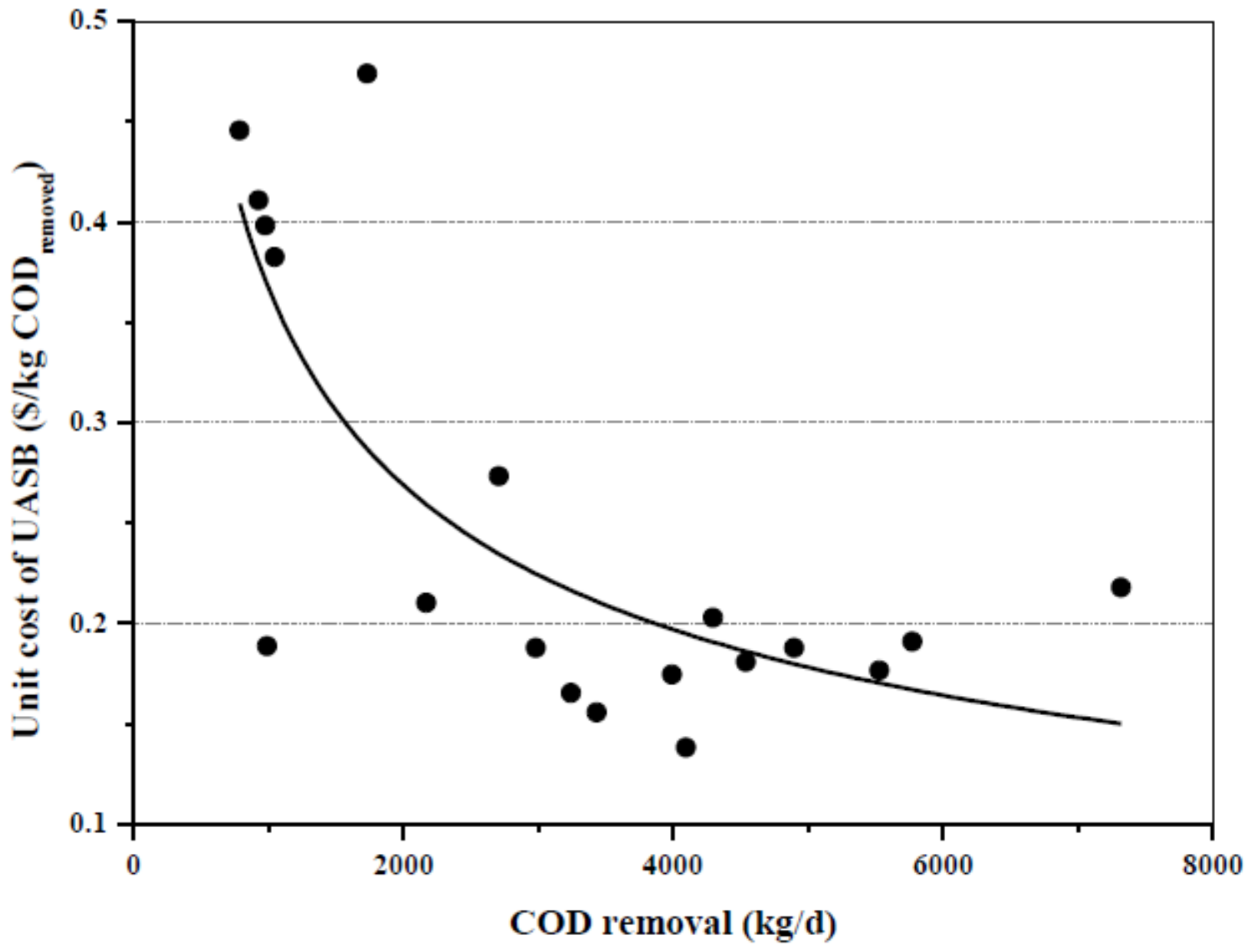

Figure 22

Unit cost of UASB 